\title{
OCORRENNCIA DE DIAS SECOS CONSECUTIVOS NA REGIÃO DE CACHOEIRO DO ITAPEMIRIM ESTADO DO ESPÍRITO SANTO
}

\author{
JOSE ALTINO SCARDUA
}

Orientador: Dr. Jesus Marden dos Santos

Dissertação apresentada à Escola Superior de Agricultura "Luiz de Queiroz", da Universidade de São Paulo, para obtenção do título de Mesíre em Agrometeorologia. 
A memória de meu pai e à minha mãe. 
AGRADECIMENTOS

Ao Dr. Jesus Marden dos Santos, orientador e coordenador do curso de Pós-graduação em Agrometeorologia.

Ao pos-graduando em Estatística Hēlio Paulo Zonta.

Aos Professores Dr. Klaus Reichardt, MS. Paulo Leonel Libar di, Dr. Nilson A. Villa Nova, Dr. Justo Moreti Filho, Dr. Afonso Decico e demais professores.

Aos funcionários da Empresa Capixaba de Pesquisa Agropecuá ria, MS. Leandro Roberto Feitoza, Samuel Silva Valle, Técnico Agrí cola, Hēlia Rosa Lima e Anancyr Burkhardt, secretārias.

Ā bibliotecária da ESALQ, Srạ Maria Elisabeth Ferreira de Car valho.

Aos colegas Italo Alberio de Souza e José da Silva Lemos e de mais colegas do curso de Pós-graduação em Agrometeorologia.

Ā Empresa Capixaba de Pesquisa Agropecuāria - EMCAPA.

Ā Empresa Brasileira de Pesquisa Agropecuāria - EMBRAPA.

Agradecemos ainda a todos aqueles que, direta ou indiretamente, contribuiram para a realização deste trabalho. 


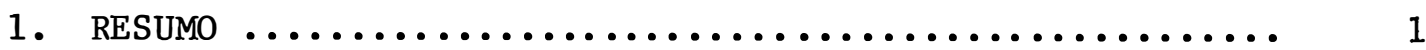

2. INTRODUÇÃO $\ldots \ldots \ldots \ldots \ldots \ldots \ldots \ldots \ldots \ldots \ldots \ldots \ldots \ldots \ldots \ldots \ldots$

3. REVISÃO DE LITERATURA ........................... 5

4. MATERIAL E METODOS ......................... 13

4.1. Área estudada e dados disponíveis ............ 13

4.2. Água disponíve1 no solo .................. 13

4.3. Evapotranspiração potencial ................ 16

4.4. Balanço de água no solo e determinação dos dias

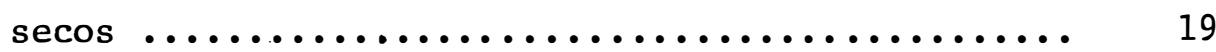

4.5. Contagem dos dias secos $\ldots \ldots \ldots \ldots \ldots \ldots \ldots \ldots \ldots \ldots . \ldots 21$

5. RESULTADOS E DISCUSSÃO $\ldots \ldots \ldots \ldots \ldots \ldots \ldots \ldots \ldots \ldots \ldots \ldots \ldots \ldots \ldots \ldots$

5.1. Āgua disponíve1 ...................... 23

5.2. Evapotranspiração potencial ................ 29

5.3. Contagem de dias secos consecutivos ........... 29

5.4. Sequências de dias secos anuais, trimestrais e

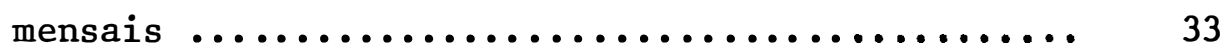

5.5. Distribuição de probabilidade da variável "número mínimo de dias secos consecutivos mensais" ...... 37

6. CONCLUSÕES $\ldots \ldots \ldots \ldots \ldots \ldots \ldots \ldots \ldots \ldots \ldots \ldots \ldots \ldots \ldots \ldots \ldots$ 
Pāgina

7. SUMMARY

8. LITERATURA CITADA $\ldots \ldots \ldots \ldots \ldots \ldots \ldots \ldots \ldots \ldots \ldots \ldots \ldots \ldots \ldots$

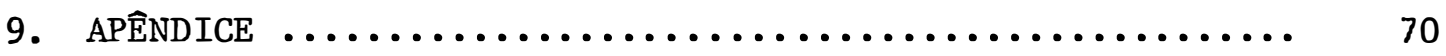


Foi estudada a ocorrência de seca numa ārea do sul do Estado do Espírito Santo, representada climaticamente pelos dados do posto meteorológico de Cachoeiro do Itapemirim. As secas foram medidas em"dias secos consecutivos" e os "dias secos", determinados pelo método climatoló gido de balanço de água no solo, descrito por VAN BAVEL (1953) e por MORE TI (1965), para as quantidades de $15 \mathrm{~mm}, 35 \mathrm{~mm}, 45 \mathrm{~mm}, 60 \mathrm{~mm}, 100 \mathrm{~mm}$ e $140 \mathrm{~mm}$ de água disponível, com base nas curvas características de umidade de dois solos, representativos e considerando-se diferentes profundidades. Utilizando-se normais climatológicas de Cachoeiro do Itape mirim, estimou-se,pelo método de Penman, a evapotranspiração média diāria para cada mês e com os dados diārios de precipitação de um período de 37 anos, foram determinados os períodos de dias secos consecutivos mensais, trimestrais e anuais.

Comparando-se a duração e frequência dos períodos secos pa ra meses, trimestres e anos, verificou-se que, $23 \%$ do total de dias secos ocorreu em sequências maiores que 31 dias consecutivos. Entre as contagens por trimestre e por ano, não houve diferença, em número e duração das sequências, que pudesse ser considerada significativa. 
Foram determinadas as probabilidades empíricas de ocorrer números mínimos de $1,4,7,10,13,16,19,22,25$ e 28 dias secos consecutivos para cada mês e cada quantidade de āgua disponível. Verificou-se que às frequências do número mínimo de dias secos consecutivos apresentaram uma distribuição normal, o que tornou possível traçar, um pa pel de probabilidade, as retas das probabilidades teóricas de ocorrer números mínimos de 1 a 31 dias secos consecutivos. A partir dessas retas foram traçados os gráficos do número mínimo de dias secos consecutivos es perado em cada mês e para cada quantidade de água disponível, aos níveis de $5 \%, 10 \%, 20 \%, 30 \%, 40 \%$ e $50 \%$ de probabilidade. 
Fixando-se as características do solo, a disponibilidade de água às plantas depende da quantidade e distribuição da precipitação e da taxa de evapotranspiração. Quando a evapotranspiração r permanece maior do que a precipitação por um período.suficientemente longo, a 汭gua disponível no solo diminui até um ponto em que as plantas não conseguem mais retirar uma quantidade suficiente para manter seu turgor e crescimen to normais. Persistindo a condição de não reabastecimento de água no so1o, a seca torna-se cada vêz mais severa em intensidade e duração, podendo afetar a produtividade ou mesmo levar as plantas à morte.

Devido à distribuição irregular das chuvas ao longo do ano, a seca, considerada sob o aspecto agrícola, è um fenômeno de ocorrência comum, mesmo em regiões úmidas e sub-úmidas, causando prejuízos em to do o mundo e constituindo-se numa das principais fontes de risco agríco1a.

As deficiências de água no solo por escassez e/ou má dis tribuição das chuvas, são frequentes e bastante severas em todo o Estado do Espírito Santo. A aplicação do método de balanço de āgua de Thornth - 
waite e Mather (1955), considerando-se um armazenamento de água de 125 $\mathrm{mm}$, mostra que um grande número de locais no Estado apresenta déficit em sete meses do ano, não sendo raro aqueles com nove meses de deficiência hỉdrica.

A região estudada neste trabalho, incluindo o muniçípio de Cachoeiro do Itapemirim, bem como outras áreas de importância agrícola por sua extensão e localização, apresenta déficit hídrico anual superior a $150 \mathrm{~mm}$. Considerando-se um armazenamento de $100 \mathrm{~mm}$ de água no solo, o balanço hídrico de Thornthwaite e Mather (1955) indica, para a cidade de Cachoeiro do Itapemirim, dez meses consecutivos de déficit hídrico, perfa zendo um total anual de $203 \mathrm{~mm}$.

A ocorrência de déficits de āgua no solo durante a maior parte do ano assume um papel importante na limitação das atividades agrícolas na região de Cachoeiro do Itapemirim e outras extensas āreas agrícolas do Estado com condições climáticas semelhantes. Assim, as tentativas para se determinar a severidade, distribuição e probabilidade de ocor rência de déficits hídricos nessas āreas fazem-se necessārias como estu dos básicos para decisões no planejamento agrícola, escolha de melhores é pocas de plantio, avaliação de riscos, previsão de colheitas e necessidades de āgua para irrigação.

Neste trabalho utilizou-se um método climatológico de balanço de água no solo para estimar, diariamente, a quantidade de água dis ponível às plantas e as probabilidades de ocorrência de secas caracteri zadas como períodos de dias secos consecutivos. 
De acordo com THORNTHWATTE (1947) a seca é o fenômeno natural que mais tem causado prejuizo à agricultura. A ocorrência de perío dos secos dificulta ou mesmo impossibilita a atividade agrícola nas regiões āridas e semi-áridas e devido a que as chuvas não se distribuem, ao longo do ano, de modo a suprir sempre as necessidades de água das cultu ras, ocorrem déficits hídricos e consequente queda da produtividade, mesmo nas regiões úmidas e sub-ūmidas.

Segundo PALMER (1965), dependendo do interesse específico de cada um, a seca tem sido estudada sob diferentes aspectos a saber: econômico, hidrológico, climático e agrícola, sendo difícil uma definição completa e adequada para este fenômeno. THORNTHWAITE (1947) afirmou que a seca fica adequadamente descrita como uma condição em que a quantidade de água perdida por evaporação e transpiração excede aquela disponível no solo. Nessa condição as plantas sofrem por falta de umidade no solo, não hā reposição de água das camadas mais profundas. Portanto, hã uma interrelação entre os diversos aspectos da séca, não havendo necessidade de distinção entre seca ċlimática, biológica ou hidrológica. 
Em agricultura, as diversas maneiras de caracterizar a seca são devidas mais a dificuldades de medir e quantificar o fenômeno do que às discordâncias quanto à sua definição. A busca de um moodo prático de caracterizar a seca numa escala regional e em áreas carentes de informações levaram à adoção de grandes simplificações. Assim, muitos auto res a tem quantificado com base somente numa deficiência da precipitação. BLUMENSTOCK (1942) considerou que uma série de dias secos terminava no mo mento anterior a um período de 48 horas, durante o qual ocorreu uma preci pitação de 2,5 mm ou mais. LAWRENCE (1957) definiu dia seco aquele em que choveu até $0,1 \mathrm{~mm}$. AMIR e outros (1977) consideraram dia seco aquele em que a chuva foi menor do que $2,5 \mathrm{~mm}$. SILVA e outros (1977), com base na evapotranspiração potencial média da baixada fluminense, estimada em $5 \mathrm{~mm}$ dia, consideraram dia seco aquele em que a chuva foi menor do que $5 \mathrm{~mm}$, MEDHI (1976) definiu dia seco como aquele em que nenhuma precipita ção foi observada. BARGER e THOM (1949ace 1949b) usaram a produtividade de milho como critério para determinar se havia ou não ocorrido seca.

HARDGREAVES (1974) classificou āreas de Nordeste brasileiro quanto à sua potencialidade agrícola, através de um índice de disponibilidade de umidade determinado a partir da precipitação que ocorria com 75\% de probabilidade e da evapotranspiração.

Devido às dificuldades de limitações dos processos de medi da de umidade do solo, conforme relataram MATHER (1954), BAYER (1965) e RIDER (1958), tem-se tentado determinar as condições de estresse através de medidas da água na planta. BEHBOUdIAN (1977) verificou que, em pepi no, pimenta doce e tomate, o potencial de āgua na folha pode ser usado co mo parâmetro indicador de deficiência de água na zona das raízes. Entre tanto, as necessidades de irrigação e as condições de seca tem sido deter minadas em função do conteúdo de umidade disponível às plantas na zona das raízes. Conforme BAYER (1965), a introdução do conceito de evapo: transpiração potencial e dos métodos relativamente simples para sua estimativa a partir de dados meteorológicos, levou à imediata compreensão de que essa abordagem, juntamente com fatores adequados do solo e da cultu ra, era a maneira mais promissora para se conhecer a variação da umidade atual do solo. 
A possibilidade de estimar a evapotranspiração atual a par tir da evapotranspiração potencial e o carater regional das fórmulas empíricas para determinação desta ūltima levaram à proposição de um grande número dessas fórmulas. DOORENBOS e PRUITT (1975) relacionaram mais de trinta delas. As mais usadas tem sido as de. Thornthwaite (1948), Bläney e Criddle (1950) e Penman (1948), as quais são apresentadas e comentadas por PENMAN (1963) e por ROSENBERG e outros (1968). Segundo PENMAN (1963) apesar das diferenças de opiniões entre os autores, hä um conceito comum de que, em condições de total cobertura do solo pela cultura e de abundan te suprimento de água, a taxa de transpiração depende principalmente das condições atmosférica.

De acordo com TANNER (1968) e PELTON e outros (1960) os mé todos empíricos de cálculo de evapotranspiração potencial que se baseiam em dados de radiação líquida são os mais precisos. Segundo PELTON e outros (1960), a defasagem entre radiação líquida e temperatura e a advec ção são as principais fontes de erro do método de Thornthwaite e dos demais métodos que usam a temperatura média no cálculo da evapotranspiração potencial. As correlações entre radiação líquida e evapotranspiração e entre radiação líquida e temperatura média deixam de existir para perío dos curtos e, nesse caso, a temperatura média nạo é uma medida adequada da energia disponível usada na evapotranspiração.

De acordo com BAYER (1965) há divergência entre os autores a respeito do valor das fórmulas de determinação da evapotranspiração potencial a partir da evaporação: de tanques e a respeito de expressões que relacionam o poder evaporante do ar, como umidade relativa e déficit de pressão de vapor. Segundo esse autor, Thornthwaite e Mather (1955) afirmaram que a umidade da atmosfera não è uma propriedade conservativa do ar e portanto não é possível determinar a evapotranspiração potencial a partir da evaporação de tanques ou de medidas de umidade. RIDER (1958), :ao contrārio, afirma que a evaporação é governada principalmente pela radiação solar, com as propriedades da massa de ar excercendo uma influência muito menor e por isso a evaporação de tanques é um índice aproximado de evapotranspiração potencial, principalmente em regiões ūmidas. DOOREN BOS e PRUITT (1975) citam como mais precisas as estimativas de evapotrans piração obtidas a partir de medidas da radiação líquida, da fórmula de 
Penman e de medidas da evaporação de tanques quando bem situados e em con dições de ventos fracos.

Em virtude das discordâncias quanto à precisão das diversas fórmulas empíricas de estimativa da evapotranspiração potencial e do carater regional ou mesmo local dessas fórmulas, elas têm.sido extensivamente testadas, principalmente as de uso mais comum. Dentre os traba lhos dessa natureza podem ser citados os de RICKARD (1957), SMITH (1959), PRUITT e JENSEN (1955), DECKER (1962) , KING e HEER-AMISSAH (1967), BEHN KE e MAXEY (1969), TURC (1961), PARMELE e McGUINESS (1974), SEGUIN (1975) , LINACRE (1977), CAMARGO (1966), FERREIRA (1972), ,SCALOPI (1972) e Sediyama e Bernardo (prelo) citados por BERNARDO (1977). $\therefore$ A anālise dos reusltados obtidos nesses trabalhos mostra que, de um modo geral, as estimativas mais précisas da evapotranspiração potencial foram consegui das pelo uso de fórmulas propostas ou modificadas para as condições 1ocais, através de correlação com medidas de radiação líquida ou global e pela equação de Penman, principalmente quando foram consideradòs períodos mais curtos, de dez dias ou menos. Pode-se concluir também que, nos casos em que esses métodos não foram os melhores, os seus resultados apre sentaram boa concordância com os valores medidos.

E comumente aceito que a perda de água do solo pela evaporação e transpiração é governada por fatores do solo da planta e da atmosfera. Segundo LEMON e outros (1957) a evapotranspiração não pode ser estimada com base somente em variāveis atmosféricas; a tensão da umidade do solo não governa sozinha a perda de água pelas plantas e estas, por sua vêz, exercem, direta ou indiretamente, restrições variáveis na transferência de àgua do solo à atmosfera.

De acordo com LEHANE e STAPLE (1953), o fato de, em solos de textura mais fina, as plantas resistirem mais à seca não parece ser de vido a que esses solos armazenam uma maior quantidade de água, mas porque a maior parte da água disponível é retida a tensões mais altas do que nos solos mais arenosos, controlando o uso de água pelas plantas.

DENMEAD e SHAW (1962), num experimento bastante elucidativo com milho, demonstraram que a transpiração diminui com o secamento do solo de diferentes modos, dependendo da demanda atmosférica. Os autores demonstraram ainda que resultados discordantes como os obtidos por Veihe- 
meyer e Hendrickson (1928), Thornthwaite e Mather (1955) e Pierce (1958), foram devidos às diferentes condiçōes de demanda atmosférica em que foram realizados os trabalhos. Outros autores, como LETEY e BLANK (1961), LEMON e outros (1975), EAGLEMAN e DECKER (1965), GAVANDE e TAYLOR (1967), MILLAR e GARDNER (1972), YANG e JONG (1972) e AL-KHAFAF e outros (1978), obtiveram resultados de decréscimo do uso de água com o secamento do solo "que se ajustam aos resultados apresentados por DENMEAD e SHAW (1972).

0 efeito do estágio de crescimento no uso de água foi estu dado, entre outros, por DENMEAD e SHAW (1962), FRITSCHEN e SHAW (1961), NANKEN e outros (1968) e SCARDUA (1970). De modo geral, os resultadds ob tidos indicam um aumento do consumo de água com o erescimento da cultura até a fase adulta e um maior consumo nos tratamentos mantidos com melhor suprimeiro de āgua.

DENMEAD e SHAW (1962) e FRITSCHEN e SHAW (1961) verifica ram que, em milho, o uso de água cresceu até a fase adulta, manteve-se constante por duas semanas e então diminuiu até o valor inicial. NANKEN e outros (1968) observaram que, na cultura de algodão, mantida a diferentes níveis de umidade no solo, a evapotranspiração cresceu visivelmente depois de decorridos 20 a $30 \%$ da estação de crescimento a partir do plantio, atingindo um máximo a $70 \%$ e que os tratamentos mais úmidos consumi ram mais água. SCARDUA (1970) trabalhando com milho irrigado a diferentes níveis, verificou que o consumo de água cresceu atē atingir um valor máximo por ocasião da formação das espigas.

SCALOPI (1972) encontrou. em cultura de batata, dois estágios distintos para o consumo de água ; o primeiro até o 50 ọ dia e o segundo do 50 a a 909 dia do plantio. RITCHIE e BURNETT (1971) verifica ram que tanto a evapotranspiração como a taxa relativa de transpiração, em culturas de algodão e sorgo com bom suprimento de água, cresceram com o número de dias após a emergência, com a cobertura do solo e com o índice de ärea foliar.

Resultados semelhantes foram obtidos por AL-KHAFAF ce outros (1978) em cultura de algodão, nos tratamentos bem supridos de água. GORNAT é outros (1971) entretanto, mostraram que a razão evapotranspira ção/ evaporação do tanque classe A, além de ter apresentado uma tendên cia decrescente com o aumento da cobertura do solo, não teve nenhuma rela 
ção lógica com o índice de ārea foliar.

A caracterização da seca agrícola torna-se difícil quando encarada apropriadamente como uma resposta biołógica aos fatores do meio. A espécie de planta, seu estágio de crescimento, as características do solo e os fenômenos meteorológicos são fatores que devem ser considera dos e desse modo a sua caracterização tende a se restringir a pequenas à reas ou os resultados obtidos tornam-se de uso difícil nos trabalhos em escala regional.

A fim de se obter uma maior simplificação nos estudos de seca agrícola, tem-se considerado o aspecto meteorológico como básico e a seca como uma função da demanda e do suprimento de água. Dessa maneira os métodos climatológicos de balanço de āgua no solo têm facilitado as estimativas das necessidades de irrigação e os estudos de ocorrência de secas, principalmente em āreas de maior extensão e carentes de informações. Existindo dados meteorológicos cobrindo um período suficiente mente longo, esses métodos permitem estudos de probabilidade de ocorrência de diferentes níveis de água no solo e de condições de seca nas diversas épocas do ano.

Vārios métodos de balanço de água no solo foram propostos. VAN BAVEL e WILSON (1952) descreveram um método simples de balanço diārio de água no solo e deram um exemplo de sua aplicação na determinação das necessidades de irrigação para a cultura do fumo. 0 método consiste em se contabilizar as chuvas e irrigações como adições de água no so1o e a evapotranspiração potencial como retiradas dessa água. Quando o total diārio de precipitação ultrapassa a quantidade de água disponível que o solo pode armazenar na zona das raízes, o excesso é desprezado. São desprezados também os valores netativos do balanço. Segundo os auto res esse método foi proposto, entre outros, por Thornthwaite (1946).

MATHER (1954), aplicando esse método aos dados de 20 anos determinou o curso anual da água disponível no solo a diferentes níveis de probabilidade. Comparou os valores calculados de água no solo com os valores medidos e verificou que a concordância entre eles foi boa.

VAN BAVEL (1953) utilizou o mesmo método de balanço de àgua no solo para um estudo de probabilidades de ocorrência de "dias secos" para a cultura do fumo, durante sua estação de crescimento. 0 au- 
tor definiu dia seco como um período de 24 horas, no qual o estresse de umidade no solo excede um valor a partir do qual pode-se considerar: que os processos produtivésc da cultura são apreciavelmente reduzidos. As e tapas para a determinação dos dias secos para a cultura de fumo na Caroli na do Norte foram as seguintes:

a - Como a fase de crescimento da cultura abrangia um período de 105 dias, de 15 de maio a 27 de agosto, apenas esse período do ano foi estudado, durante 59 anos.

b - Com base em evidências experimentais, a profundidade média do sistema radicular foi adotada como sendo de $20 \mathrm{~cm}$ e como água disponível à cultura foi considerada aquela retida entre a capacidade de campo e $800 \mathrm{~cm}$ de coluna d'água de tensão. Dispondo das curvas caracterís ticas de umidade e das densidades dos solos, foram determinadas as quantidades de água disponível que os diversos solos podiam reter e adotado um valor médio representativo das condições estudadas.

c - A evapotranspiração potencial diāria foieestimada pela fórmula de "? Thornthwaite, utilizando as normais de temperatura.

d - Foi considerado que no primeiro dia do período, no primeiro ano, o solo continha toda a água disponível. Daí em diante, a evapotranspiração potencial foi subtraída diariamente da água do solo e as pre cipitações foram somadas. Só foram computadas as quantidades de chuva necessārias para repor a āgua disponível máxima, supondo os excessos perdidos por deflúvio superficial. Quando, pela subtração da evapotranspiração, foram obtidos valores negativos do balanço, estes também foram cancelados.

e - Foram computados como dias secos aqueles em que o balanço de água no solo teve valores zero ou negativos.

f - Determinaram-se as frequências dos dias secos ocorridos e traçaram se as curvas das probabilidades empíricas de se ter mais do que um dado número de dias secos durante a estação de crescimento da cultura. 
(1953) num estudo de incidência e probabilidade de ocorrência de dias secos para períodos mensais e anuais em sete municípios da zona canavieira do Estado de São Paulo e estimou a quantidade de água necessária para irrigação, a um nível de $90 \%$ de probabilidade, para cada localidade e para três quantidades de àgua disponível.

THORNTHWAITE e MATHER (1955) propuseram um método de balan ço de āgua no solo em que a evapotranspiração da āgua contida abaixo da capacidade de campo diminui linearmente com o secamento do solo, na razão de $1: 1$. Assim, a evapotranspiração é igual à evapotranspiração poten cial quando o solo está na capacidade de campo e igual à metade da evapotranspiração potencial quando o solo tiver perdido a metade da água dispo nível. Os autores obtiveram uma estreita concordância entre os valores de água no solo calculados por esse método e os valores medidos.

HOLMES e ROBERTSON (1959), ao proporem um modelo de balanço de água no solo, consideraram este dividido em duas camadas: uma cama da superficial, onde toda a água é perdida à taxa da evapotranspiração po. tencial, antes de ocorrer qualquer perda em camadas mais profundas, e uma camamda inferior denominada "zona de transição", cụja āgua é evapotranspi rada a taxas decrescentes, com o secamento do solo.

Num modelo de balanço climatológico de água no solo, em florestas decíduas, proposto por ITEM (1973), foi considerado que a perda de água do solo se dava por percolação e pela evapotranspiração corrigida em função do secamento do solo e da demanda atmosférica conforme DENMEAD e SHAW (1962). 0 autor adotou, ainda, um fator de correção da evapotrans piração para condições de existência de água interceptada e considerou que existia água interceptada, no máximo até o dia seguinte a uma chuva maior do que a evapotranspiração.

SAXTON e outros (1974) propuseram um modelo detalhado de balanço diārio da āgua do solo. As estimativas da evaporação do solo, da água interceptada e a estimativa da transpiração foram feitas separadamen te, e combinadas para estimar a evapotranspiração. 


\section{1 - Ërea estudada e dados disponíveis.}

Foi estudada uma ārea localizada no sưl do Estado do Espírito Santo, no vale do Rio Itapemirim, delimitada por uma isolinha ' de 150mm de déficit hídrico anual (figura 1) e caracterizada pelos dados da. estaçăo meteorológica do Ministério da Agricultura localizada na cidade de Cachoeiro do Itapemirim, a $20^{\circ} 51^{\prime}$ de latitude, $40006^{\prime}$ de longitude e 35 de altitude.

Os dados disponíveis para a realização do trabalho são as normais climatológicas de Cachoeiro do Itapemirim, fornecidas pelo Instituto Nacional de Meteorologia (quadro 1), a Carta de Levantamento de Reco nhecimento dos solos do Estado do Espírito Santo, da Divisão de Pesquisas Pedológicas do Ministério da Agricultura e as medidas diárias de precipitação, durante 37 anos $(1940$ - 1976), fornecidas pelo D.N.A.E. do Ministé rio das Minas e Energia.

4.2 - Āgua disponível no solo.

Para se adotar valores de água disponível concordantes com aqueles que possam ocorrer na área estudada, determinou-se a capacidade de 
armazenamento dos solos representativos daqueles predominantes na ärea, para três diferentes profundidades e entre as tensões de 0,1-15atm e 0,3 - 15atm.

Considerou-se os latosolos Vermelho-Amarelos Distrōficos. LVd2, LVd4 e LVd5 como soḷos similares quanto à capacidade de retenção de àgua, podendo, por isso' serem representados pelo LVd2. Do mesmo modo, as Terras Roxas Similares Eutróficas Podzólicas TRPel e TRPe2 foram consideradas representadas pela TRPel.

Os solos representativos, LVd2 e TRPe1, foram amostrados às profundidades de $15 \mathrm{~cm}, 45 \mathrm{~cm}$ e $80 \mathrm{~cm}$, utilizando-se o anel de Uhland e determinadas a densidade global $\left(\mathrm{g} / \mathrm{cm}^{3}\right)$ de cada amostra. As profundidades de $15 \mathrm{~cm}, 45 \mathrm{~cm}$ e $80 \mathrm{~cm}$ foram Consideradas representativas das camadas de 0$30 \mathrm{~cm}, 30-60 \mathrm{~cm}$ e $60=100 \mathrm{~cm}$, respectivamente.

A partir dos valores da densidade global, as amostras deformadas foram compactadas em aneis de volume conhecido, visando devolver ao solo a quantidade original de poros, determinando-se os valores da umidade a diferentes tensões, utilizando-se placas porosas de Richards. Multiplicando-se a umidade por peso pela densidade global obtiveram-se os valores da umidade por volume $\left(\mathrm{cm}^{3} / \mathrm{cm}^{3}\right)$ para cada solo, camada e tensão, traçando-se as respectivas curvas características de umidade.

A água disponível ou capacidade de armazenamento dos solos LVd2 e TRPe1, para as profundidades de $30 \mathrm{~cm}, 60 \mathrm{~cm}$ e $100 \mathrm{~cm}$ e entre as ten sões de 0,1 - 15atm e 0,3 - 15atm, foi determinada empregando-se a fórmula usual:

$$
\mathrm{AD}=\left(\theta_{\mathrm{s}}-\theta_{\mathbf{i}}\right) \cdot \mathrm{H} \quad \cdot \quad \cdot \quad \cdot \quad \cdot(1)
$$

onde, $\mathrm{AD}$ é a pagua disponível em mm de altura, $\Theta_{\grave{j}}$ e $\theta_{i}$ são as umidades por volume nos limites superior e inferior de ägua no solo, respectivamen te, em $\mathrm{cm}^{3} / \mathrm{cm}^{3}$ e $\mathrm{H}$ é a profundidade ou espessura da camada de solo em mm. Com base nos valores de armazenamento encontrados, adotou-se como representativas das condições mais comuns na ärea estudada, as quantidades de àgua disponível de $15 \mathrm{~mm}, 35 \mathrm{~mm}, 45 \mathrm{~mm}, 60 \mathrm{~mm}, 80 \mathrm{~mm}, 100 \mathrm{~mm}$ e $140 \mathrm{~mm}$. Para cada uma dessas quantidades de āgua disponível no solo foram determinadas as probabilidades de ocorrência de dias secos consecutivos em cada mês do calendārio. 


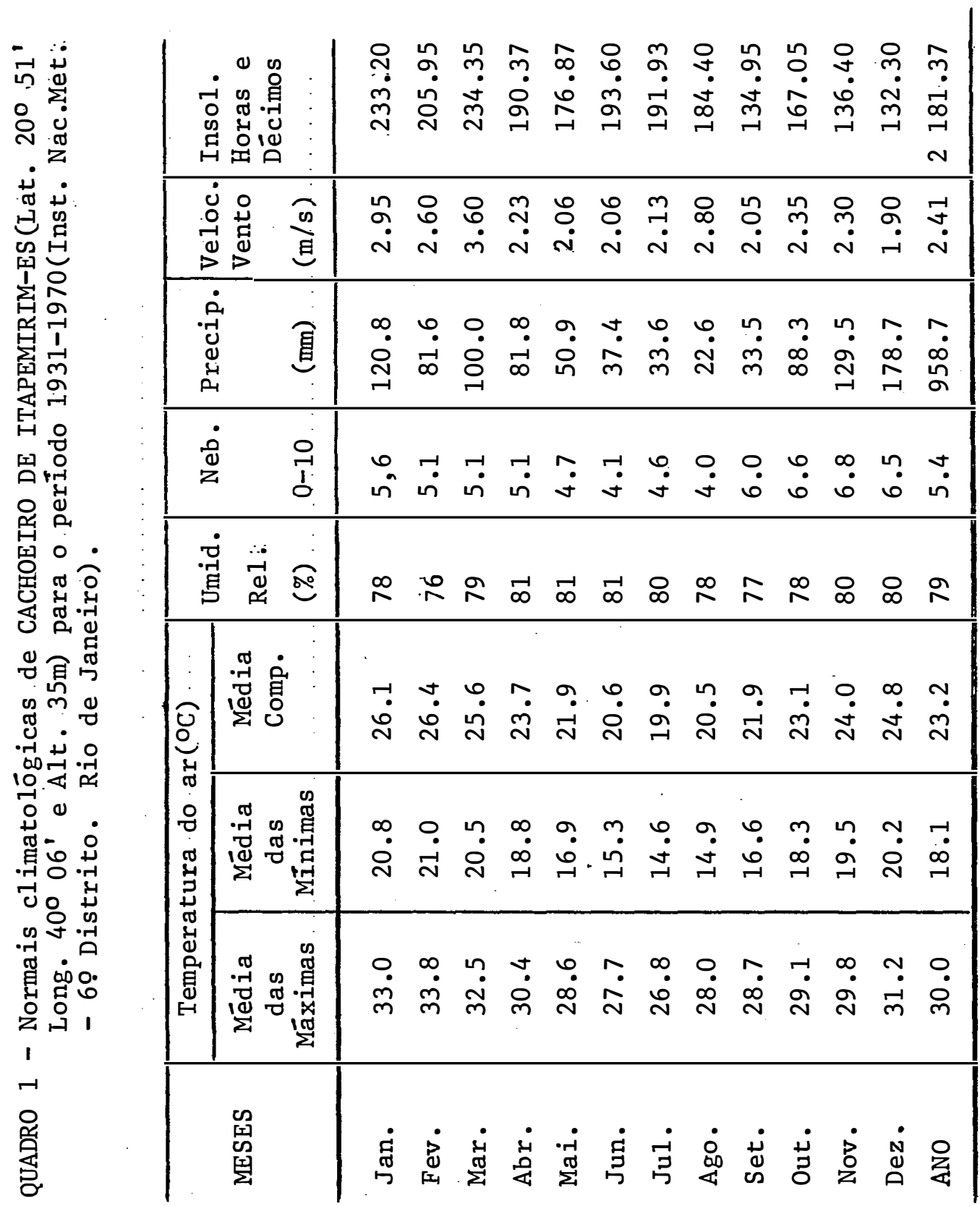


4.3 - Evapotranspiração potencial.

A evapotranspiração potencial média diāria para cada mês do calendário foi estimada pela fórmula de Penman, utilizando os dados climatológicos normais de 40 anos para Cachoeiro do Itapemirim. Empregou-se a fórmula de Penman escrita na forma:

$$
\operatorname{ETP}=\frac{\Delta / \gamma Q^{*}+E a}{\Delta / \gamma+1} \cdot \cdot \cdot \cdot \cdot \cdot
$$

onde, ETP è a evapotranspiração potencial em mm/dia, Q* è a radiação 1îquida global em mm/dia. $\Delta$ é a tangente à curva de saturação de vapor à temperatura média ao ar, em $\mathrm{mmHg} / \stackrel{\mathrm{m}}{\mathrm{C}}, \gamma$ é a constante psicrométrica em mn Hg/ọ e Ea é o poder evaporante do ar em mm/dia.

A obtenção do valor de cada parâmetro do fórmula de Penman, a partir dos dados climáticos medidos nos postos meteorológicos, será indi cada a seguir:

a) $\Delta$ : tangente à curva de saturação de vapor. Seu valor pode ser obtido de tabelas ou calculado por:

$$
\Delta=\frac{\partial e s}{\partial T}=\frac{\Delta e s}{\Delta T}=\frac{e s^{\prime}-e s^{\prime \prime}}{T^{\prime}-T^{\prime \prime}} \quad \cdot .
$$

em que es' e es'' são as pressões máximas de vapor às temperaturas $T^{\prime}$ e $T^{\prime \prime}$, respectivamente, obtidas de tabelas-psicrométricas para valores suficientemente próximos de $T^{\prime}$ e $T^{\prime \prime}$ '

Não se dispondo de tabelas, pode-se determinar es e portanto $\Delta$ pela fórmula de Tetens:

$$
\text { es }=6,11 \times 10^{\frac{a \cdot T}{b+T}}
$$

onde, $a=7,5$ e $b=237,5$.

Substituindo es pelo seu valor, dado pela fórmula de Tetens, em (3) vem:

$$
\Delta=\frac{\partial\left(6,11 \times 10^{\overrightarrow{\mathrm{b}}+\mathrm{T}} \overrightarrow{\mathrm{T}} \times 0,75\right)}{\partial \mathrm{T}}
$$


Derivando, encontra-se:

$$
\Delta=\frac{18779,5 \times 10^{\frac{\mathrm{a} \cdot \mathrm{T}}{\mathrm{b}+\mathrm{T}}}}{(237,3+\mathrm{T})^{2}} \cdot \quad \mathrm{mmHg} / \mathrm{OC}
$$

b) $\dot{\gamma}$ : constante psicrométrica. Seu valor è dado por:

$$
\ddot{\gamma}=\frac{C_{P} \cdot P}{0,622 \cdot L} \quad \mathrm{mmHg} / \mathrm{OC}
$$

onde, $C_{p}$ è o calor específico do ar úmido, o,28 cal/g. oc, P é a pres são atmosférica, tomada como sendo de $750 \mathrm{mmHg}$ quando não existem da dos medidos e L é o calor latente de vaporização da água, $590 \mathrm{cal} / \mathrm{g}$. Então:

$$
\gamma=\frac{0,28 \mathrm{cal} / \mathrm{g} .9 \mathrm{C} \times 750 \mathrm{mmHg}}{0,622 \times 590 \mathrm{cal} / \mathrm{g}}=0,57 \mathrm{mmHg} / 9 \mathrm{C} .
$$

c) Q*: radiação líquida global. Ė dada por:

$$
\mathrm{Q}^{*}=\mathrm{K} \downarrow-\mathrm{K} \uparrow+\mathrm{L} \downarrow-\mathrm{L} \uparrow \cdot . \cdot \cdot \cdot
$$

onde;

$\mathrm{K} *=\mathrm{K} \downarrow-\mathrm{K} \uparrow=$ balanço de ondas curtas.

$\mathrm{L}^{*}=\mathrm{L} \downarrow-\mathrm{L} \uparrow=$ balanço de ondas longas.

Nos lügares onde não há medidas de radiação, pode-se estimar empiricamente os balanços de ondas curtas e de ondas longas e conse quentemente obter uma estimativa da radiação líquida global. Os balanços de ondas curtas e de ondas longas são estimados, respectivamen te, por:

$$
\begin{aligned}
& \mathrm{K}^{*}=\mathrm{K}_{\mathrm{O}}(\mathrm{a}+\mathrm{b} \mathrm{n} / \mathrm{N})(1-\mathrm{r}) \quad \cdot \quad \cdot \quad \cdot \quad \cdot \quad \cdot \quad \cdot \\
& \mathrm{L}^{*}=\sigma \mathrm{T}^{4}(0,56-0,09 \sqrt{\mathrm{e}})(0,1+0,9 \mathrm{n} / \mathrm{N}) \quad \cdot \quad \cdot
\end{aligned}
$$

Substituindo em (4) os valores dos balanços de ondas curtas e longas, dados por (5) e (6), vem: 


$$
\begin{aligned}
& Q^{*}=K_{0}(a+b n / N)(1-r)-\sigma T^{4}(0,56-0,09 \sqrt{\mathrm{e}})(0,1+0,9 n / N) \quad \cdots \quad \cdots \\
& \text { onde, }
\end{aligned}
$$

$Q^{*}=$ radiação líquida global, $\left(\mathrm{cal} / \mathrm{cm}^{2} \cdot \mathrm{dia}\right)$.

$\mathrm{K}_{\mathrm{o}}=$ radiação extra-terrestre, função da latitude e época do ano, obti da de tabelas como as de SALATi e outros (1975), (cal $\left./ \mathrm{cm}^{2} \cdot \mathrm{dia}\right)$.

$\mathrm{n}=$ insola $\underset{-}{\mathrm{s}}$ ão ou horas de brilho solar, medida pelo heliógrafo do pos to meteorológico, (horas e décimos/dia):

$\mathrm{N}$ = insolação teórica máxima, função da latitude e época do ano, obti da das tabelas apresentadas por DOORENBOS e PRUITT (1975), (horas e décimos/dia).

$\sigma \mathrm{T}^{4}=$ emissão teórica de um corpo negro à temperatura média do ar $\mathrm{T}$, em $\mathrm{oK}$, onde $\sigma$ é a Constante de Stefan-Boltzman e vale $1,17 \times 10^{-7}$ $\mathrm{cal} / \mathrm{cm}^{2} \cdot \mathrm{dia} \cdot \mathrm{OK}^{4}$.

$r$ = albedo, tomado como sendo 0,25 para superfícies vegetadas.

e = pressão parcial de vapor d'água do ar $(\mathrm{m} n \mathrm{Hg})$, dado por: $\mathrm{e}=(\mathrm{UR} / 100) . e s$, onde UR é a umidade relativa dada em porcentagem e es é a pressão máxima de vapor, em mnHg, jā definida.

$\mathrm{a}$ e $\mathrm{b}=$ coeficientes que relacionam a radiação global (K), a radiação extra-terrestre $\left(K_{0}\right)$ e a insolação relativa $(n / N)$, segundo a equa ção: $K=K_{0}(a+b n / N)$. Os valores de $\underline{a}$ e $\underline{b}$ devem ser determina dos para cada região. Para Cachoeiro do Itapemirim, seus valores foram determinados a partir da relação ętre esses coeficientes e a insolação relativa, obtida por RIETVEḶ(1978) e dada na figura 2. Foram encontrados os valores:

$$
\begin{aligned}
& a=0,24 \\
& b=:=0,52
\end{aligned}
$$

Na fórmúla de penman, ETP e Ea são dados em milímetros de àgua evapotranspirada pờdia. Assim, o termo $Q^{*}$ também deve ter essa dimensão. Como são necessārias 59 calorias para evapo rar 1mm de água, para se obter o valor da radiação 1íquida em mm/ dia, basta dividir o seu valor em $\mathrm{cal} / \mathrm{cm}^{2}$.dia, dado pela fórmula (7), por 59 .

$\mathrm{d}=\mathrm{Ea}$ : poder evaporante do ar. Seu valor é determinado empíricamente em função da velocidade do vendo a $2 \mathrm{~m}$ de altura $\left(\mathrm{U}_{2}\right)$ e do déficit 
18.

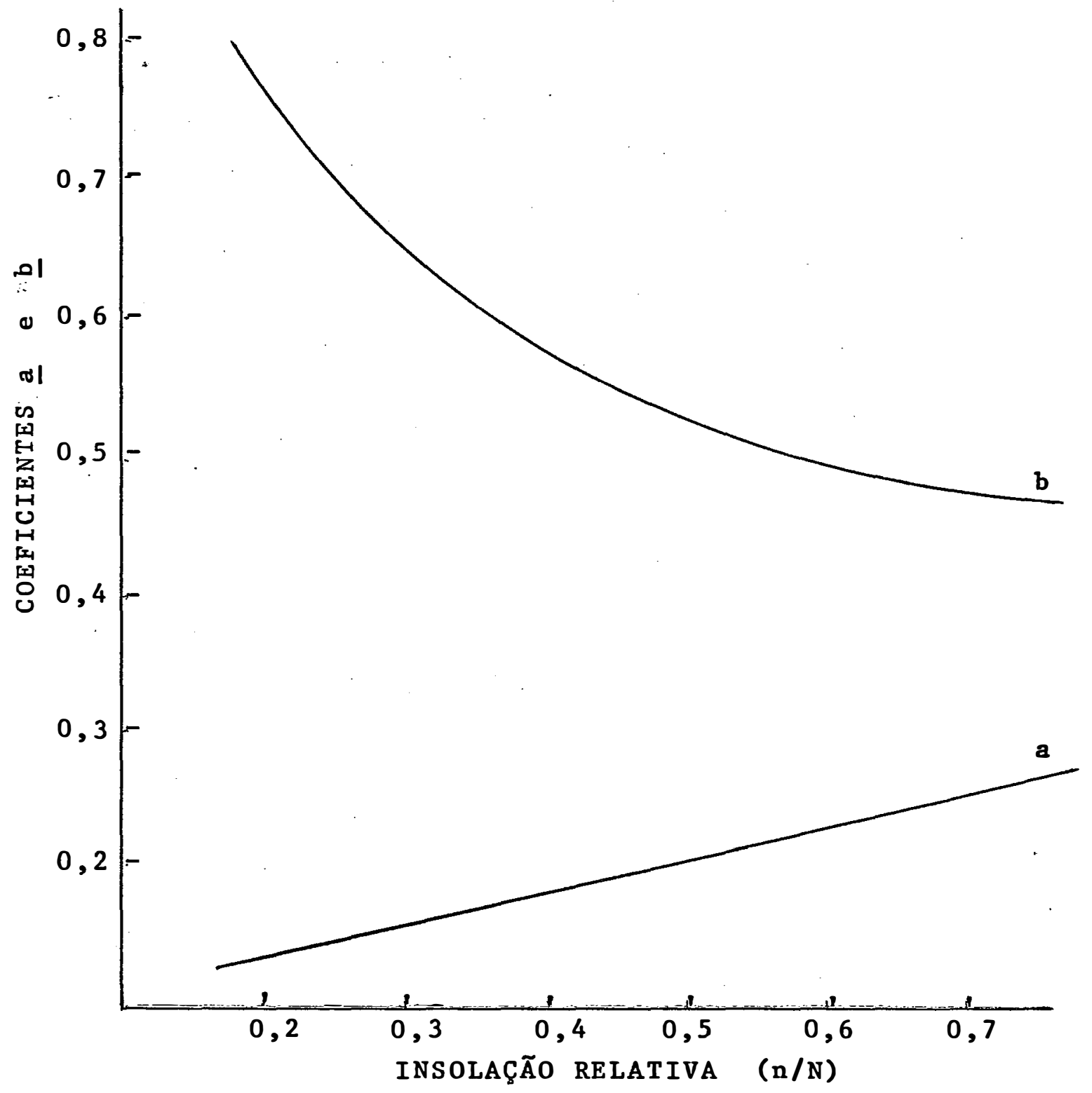

Figura 2 - Relação entre os coeficientes a e ba e a Insolação Relativa, na fórmula da Radiação Global a partir da Radiação Extra-terrestre: $K=K_{0}(a+b n / N)$, segundo RIETVEID (1978). 
de saturação de vapor. (es - e). Para a velocidade do vento em $\mathrm{Km} /$ dia e o déficit de saturação em mn $\mathrm{Hg}$, Ea é dado pela expressão

$$
\mathrm{Ea}=0,35\left(1+\frac{\mathrm{U}_{2}}{160}\right) \quad(\mathrm{es}-\mathrm{e}) \quad \mathrm{m} \mathrm{m} / \mathrm{dia}
$$

Nos postos em que a velocidade do vento é medida a uma altura $\mathrm{h}$, diferente de $2 \mathrm{~m}$, obtēm-se a velocidade a $2 \mathrm{~m}$ pela expressão:

$$
\mathrm{U}_{2}=\mathrm{U}_{\mathrm{h}} \quad\left(\frac{\ln 2}{\ln \mathrm{h}}\right.
$$

onde, $\mathrm{U}_{\mathrm{h}} \overline{\mathrm{e}}$ a velocidade do vento à altura $\mathrm{h}$.

4.4 - Balanço de àgua no solo e determinação dos dias secos.

A seca foi caracterizada em função da disponibilidade de água no solo, determinada diariamente pelo método climatológico de balanço de āgua descrito por VAN BAVEL e WILSON (1952), MATHER (1954) e THORNTHWAI TE e MATHER (1955) e foi medida em dias secos, segundo o método proposto por VAN BAVEL (1953).

No balanço de água no solo e na caracterização dos dias secos foram feitas, ainda, as seguintes suposições:

a) Nos dias em que o total de precipitação excedia a capacidade de retenção de água disponível, de uma quantidade igual ou maior do que a evapotranspiração potenciál, no dia seguinte não havia desconto na água do solo, supondo-se que a evapotranspiração seria do excesso.

b) Os dias em que o balanço de água atingiu o valor zero só foram computados como dias secos se o dia anterior foi seco. Isso ocor reu quando, após um ou mais dias secos, houve uma quantidade de precipitação exatamente igual à evapotranspiração.

Para uma melhor compreensão do método e critérios adotados no balanço de água e na determinação dos dias secos apresenta-se, no quadro 2, um exemplo hipotético para $15 \mathrm{~mm}$ de água no solo e $5 \mathrm{~mm}$ de evapotranspiração diāria, para um período de 16 dias, iniciando-se com uma condição de disponibilidade total de água no final do primeiro dia. Desse mo 
do, no início do segundo dia o solo continha os 15m de água disponível.

Verifica-se, no quadro 2 , que não houve chuva atē o dia 4. Nesse dia, a evapotranspiração, a uma taxa de $5 \mathrm{~mm}$ por dia,esgotou a água do solo. Porém, o dia 4 não foi computado como dia seco porque o dia ante rior não foi seco. No dia 5 choveu 4mm e a água no solo no final do dia foi $0+4-5=-1 \mathrm{~mm}$, portanto um dia seco. No dia 6 choveu $5 \mathrm{~mm}$, um valor igual à ETP. 0 valor negativo do dia anterior é desprezado e a água no solo no final do dia foi $0+5-5=0$ mm e o dia 6 foi computado como dia seco porque o dia anterior foi um dia seco. No dia 7 houve uma chuva de $20 \mathrm{~mm}$ que reabasteceu o solo e proporcionou um excesso de $20-12=5 \mathrm{~mm}$, igual à ETP. Portanto, no dia 8 seguinte não houve desconto no armazena mento do solo permanencendo com $15 \mathrm{~mm}$ de água disponível. No dia 9 ocorreu uma chuva de $8 \mathrm{~mm}$. No final do dia a água no solo seria de $15+8-5=$ = 18m $\mathrm{m}$. Como o armazenamento máximo é de 15m, houve um excesso de 18 - 15 = 3m, menor do que a ETP e neste caso no dia seguinte houve evapotranspiração da água do solo. No dia 10 ocorreu uma chuva de 3mm e no final do dia a água disponível no solo foi $15+3-5=13 \mathrm{~m}$. A chuva de $25 \mathrm{~mm}$ do dia 11 elevaria a água do solo para $13+25=38 \mathrm{~mm}$. Porém o solo reteve apenas $15 \mathrm{~mm}$, havendo um excesso de $38-15=23 \mathrm{~mm}$. Como o excesso foi maior do que a ETP, não houve evapotranspiração da água disponível do solo no dia 12 seguinte: Não ocorreu mais nenhuma chuva e no final do dia 15 a água do solo se esgotou, atingindo o valor zero. Entretanto o dia 15 não foi computado como dia seco porque o dia anterior não foi seco. 0 dia 16 foi um dia seco. No período de 16 dias ocorreram, entãop 3 dias secos, sendo 2 deles consecutivos. 
Quadro 2 - Exemplo de balanço de água e determinação dos dias secos, para $15 \mathrm{~mm}$ de àgua disponível no solo e $5 \mathrm{~mm}$ de evapotranspiração dia $\underline{a}$ ria.

\begin{tabular}{ccccc}
\hline Dia & $\begin{array}{c}\text { Precipitação } \\
(\text { mm) }\end{array}$ & $\begin{array}{c}\text { Evapotrans } \\
(\mathrm{mm})\end{array}$ & $\begin{array}{c}\text { Água no Solo } \\
(\mathrm{mm})\end{array}$ & $\begin{array}{c}\text { Excesso } \\
(\mathrm{mm})\end{array}$ \\
\hline 1 & 0 & 5 & 15 & 0 \\
2 & 0 & 5 & 10 & 0 \\
3 & 0 & 5 & 5 & 0 \\
4 & 0 & 5 & 0 & 0 \\
$5 *$ & $4 *$ & $5 *$ & $0 *$ & $-1 *$ \\
$6 *$ & $5 *$ & $5 *$ & $0 *$ & $0 *$ \\
7 & 20 & 5 & 15 & 5 \\
8 & 0 & 0 & 15 & 0 \\
9 & 8 & 5 & 15 & 3 \\
10 & 3 & 5 & 13 & 0 \\
11 & 25 & 5 & 15 & 23 \\
12 & 0 & 0 & 15 & 0 \\
13 & 0 & 5 & 10 & 0 \\
14 & 0 & 5 & 5 & 0 \\
15 & 0 & 5 & 0 & 0 \\
$16 *$ & $0 *$ & $5 *$ & $0 *$ & 0 \\
& & 5 & & \\
\hline
\end{tabular}

* dia seco

4.5 - Contagem dos dias secos.

As sequências de dias secos foram contadas considerando-se períodos mensais, trimestrais e anuais e foram agrupadas nas classes: $1-31, .32-41,42-51,52-61$ e $62-71$. As frequências e as porcenta gens do total de dias secos em cada classe, obtidas nas contagens mensal, trimestral e anual foram comparadas entre si.

As sequências mensais foram agrupadas nas 11 classes: zero, $1-3,4-6,7-9,10-12,13-15,16-18,19-21,22-24,25-27$ e 
28 - 31. Para cada mês do calendārio, foram determinadas as frequências e as probabilidades empíricas de ocorrência de cada classe e do número míni mo de dias secos consecutivos dado pelo limite inferior de cada classe.

Verificou-se o ajustamento da distribuição de probabilidades da variāvel aleatória, número mínimo de dias secos consecutivos, à curva normal e assim pôde-se traçar, em papel de probabilidade, para cada mês do calendārio e cada quantidade de āgua disponível, os grä́icos das retas que relacionam os números mínimos de dias secos consecutivos e as probabi lidades teóricas de sua ocorrência. A partir dessas retas foram obtidos os dados para o traçado dos grä́icos que dão os números mínimos de dias secos consecutivos esperados; aos níveis de probabilidade de 5\%, $10 \%, 20 \%$, $30 \%, 40 \%$ e $50 \%$, em cada mês e para cada quantidade de água disponível. 
23.

5 - RESULTADOS E DISCUSSÃO

\section{1 - Āgua disponível}

Os solos LVd2 e TRP el foram considerados representativos dos solos da ārea estudada com base nas informações da Carta de Levantamento de Reconhecimento dos solos da Estado do Espírito Santo, elaborada pelo Mi nistērio da Agricultura. Verificou-se que os Latosolos Vermelho - amarelos Distróficos e as Terras roxas ocupam a maior parte da ārea estudada, como mostra a figura 3 , sendo os solos restantes de pouco ou nenhum uso agrícola como os Hidromórficos, Litólicos e Areias Quartzosas. Por outro lado, entre os Latosolos e as Terras Roxas, o LVd2 e o TRPel, respectiva mente, são os mais próprios à agricultura por possuirem relevo mais ameno classificado como ondulado, enquanto, os demais possuem relevo forte ondulado e montanhoso.

A densidade global e os níveis de umidade determinados para as camadas $0-30 \mathrm{~cm}$ e $60-100 \mathrm{~cm}$ dos solos LVd2 e TRPel, às tensões de $0,001,0,03,0,06,0,3,1,0,5,0$ e 15 atm, estão no quadro 3. A partir dos valores de umidade e tensão do quadro 3 for am traçadas as curvas caracte - 
24.

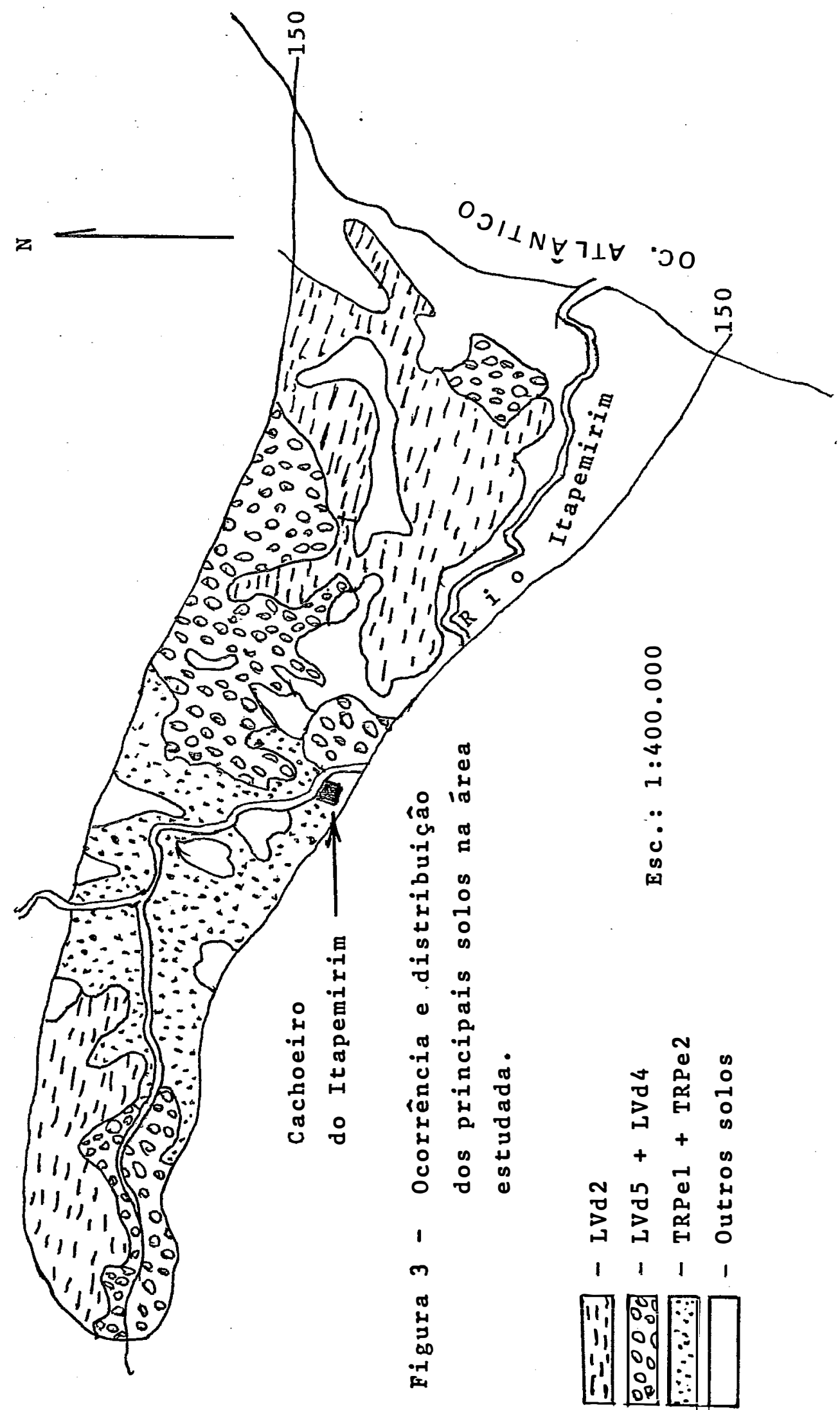




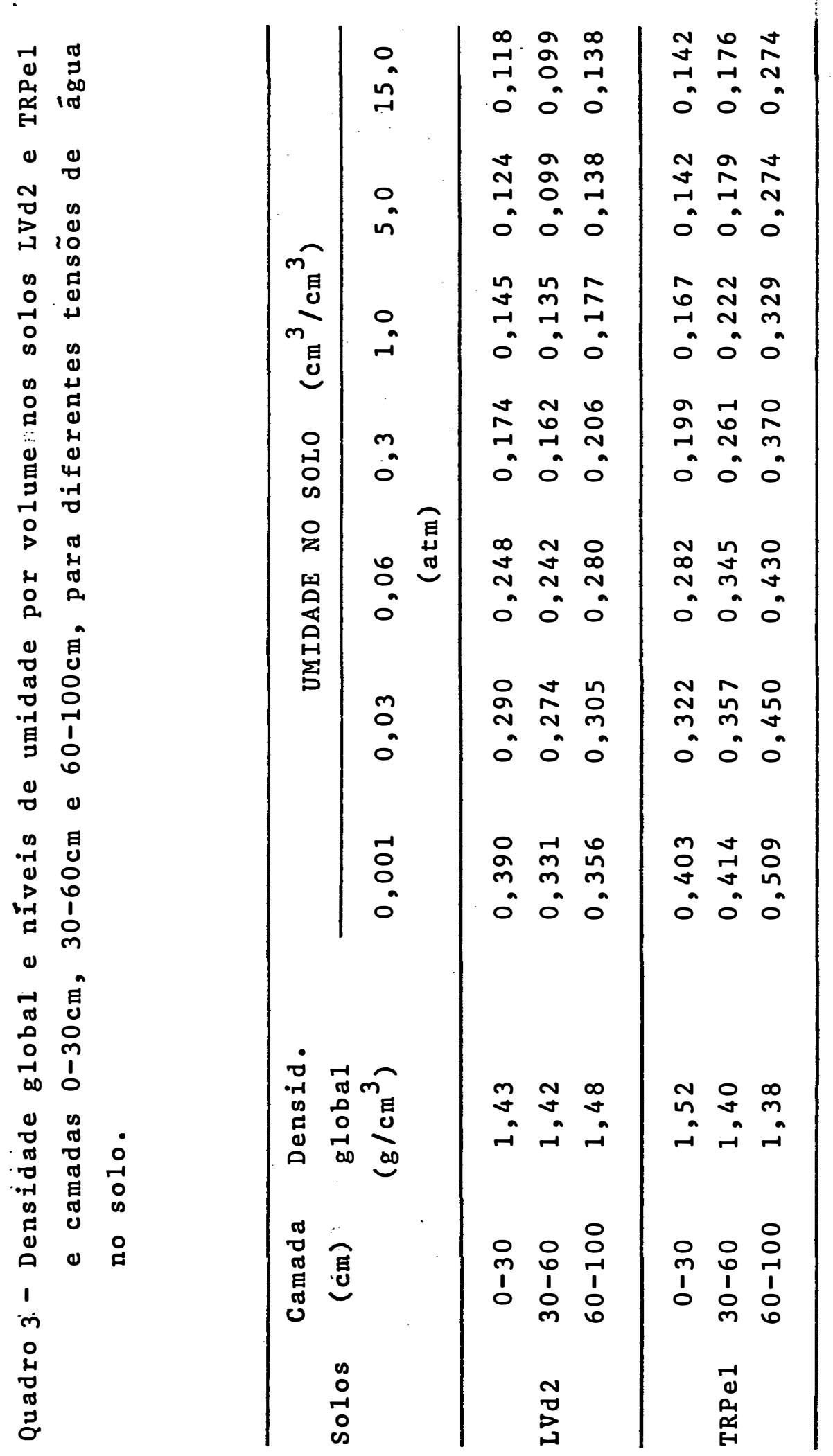




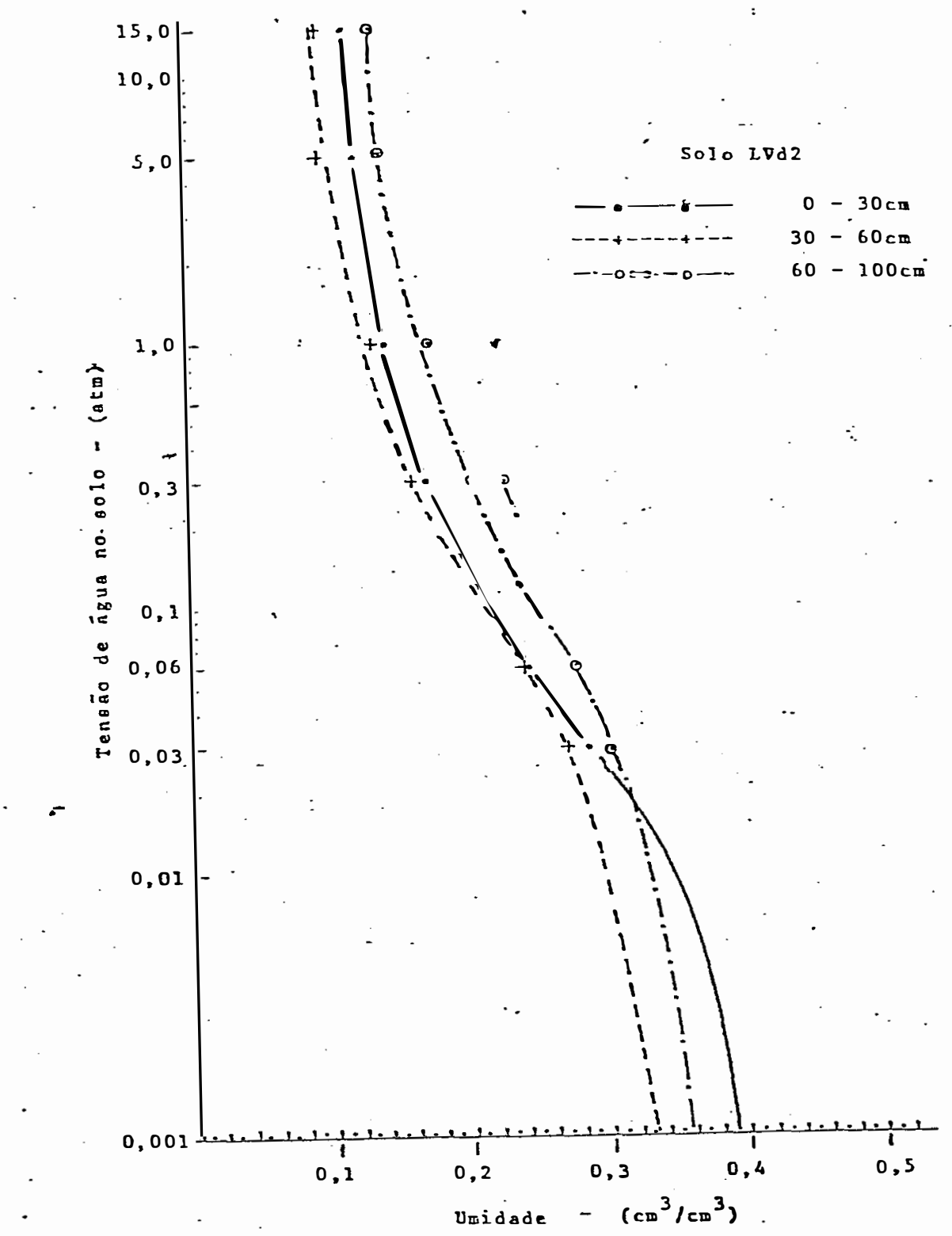

Figura 4 - Curvas características de umidade das camadas $0-30 \mathrm{~cm}, 30-60 \mathrm{~cm}$ e $60-100 \mathrm{~cm}$, para o solo LVd2. 


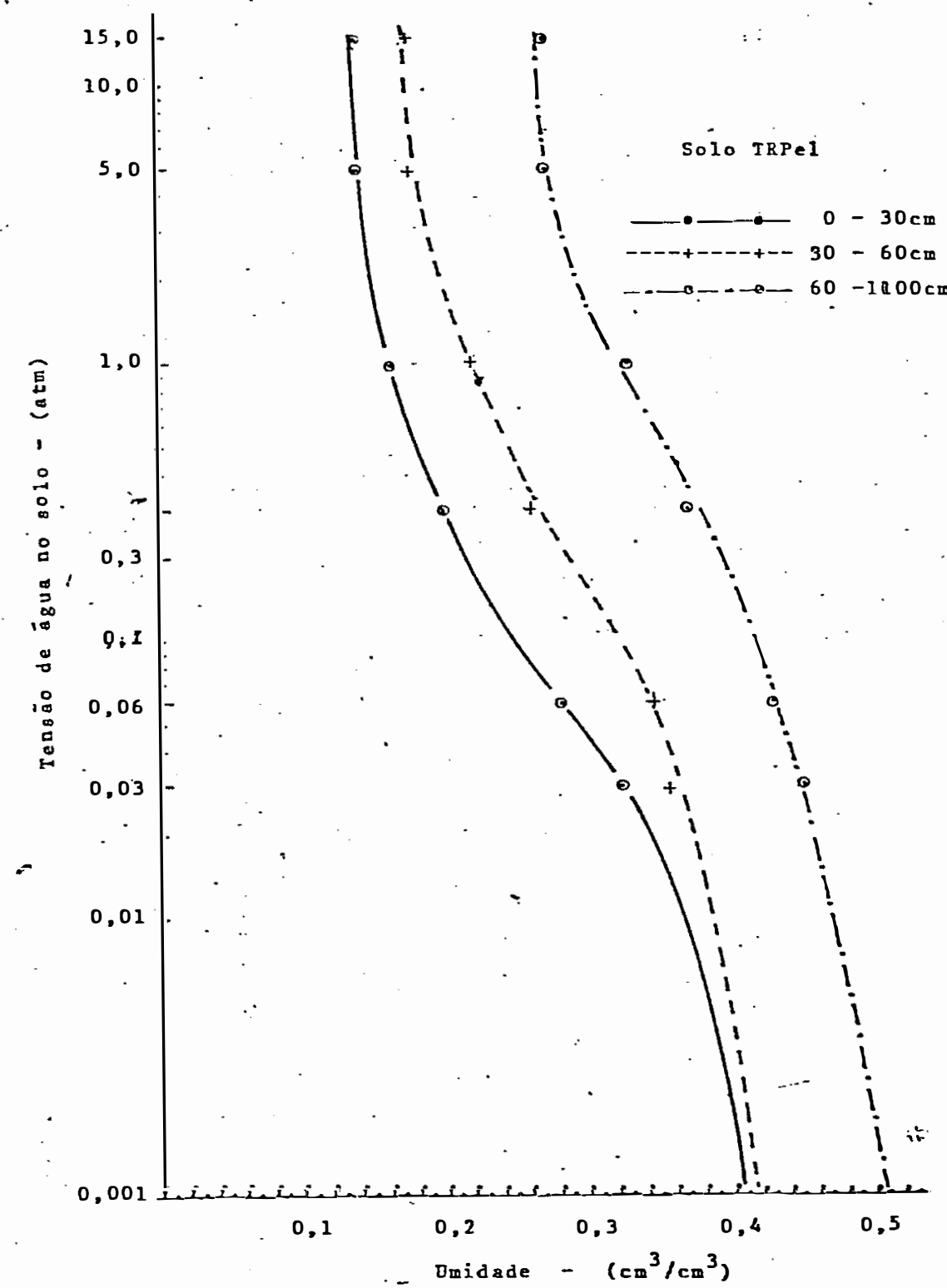

Figura 5 - Curvas características de umidade das camadas $0-30 \mathrm{~cm}, 30-60 \mathrm{~cm}$ e $60-100 \mathrm{~cm}$, , para o solo TRPel. 
Quadro 4 - Āgua disponível em milímetros de altura até as profundidades de $30 \mathrm{~cm}, 60 \mathrm{~cm}$ e $100 \mathrm{~cm}$, para os solos LVd2 e TRPe1, entre as tensões de 0,1-15atm e $0,3-15$ atm.

\begin{tabular}{lccc}
\hline & & \multicolumn{1}{c}{ Agua disponive1 (mm) } \\
\cline { 3 - 4 } Solos & \begin{tabular}{c} 
Profund $(\mathrm{cm})$ \\
\cline { 3 - 4 }
\end{tabular} & $0,1-15$ atm & $0,3-15$ atm \\
\hline LVd2 & $0-30$ & 36,3 & 18,9 \\
& $0-60$ & 63,9 & 35,7 \\
& $0-100$ & 108,7 & 62,9 \\
TRPe1 & $0-30$ & 35,4 & 17,1 \\
& $0-60$ & 78,6 & 42,6 \\
& $0-100$ & 133,0 & 81,0 \\
\hline
\end{tabular}


rísticas de umidade para cada camada de solo, dadas nas figuras 4 e 5 e fo ram obtidas as quantidades de água, em milímetros de altura, que os solos conseguem reter entre as tensões de 0,1 e 15 atm e 0,3 e 15 atm, dadas no quadro 4. Nota-se nesse quadro que a menor quantidade de água armazena da foi de $17,1 \mathrm{~mm}$ e a maior quantidade foi de 133,0 $\mathrm{mm}$. Para representar es sas quantidades, adotou-se, no balanço de água no solo, as quantidades de 15m e 140mm de água disponível, respectivamente. Para representar as quantidades de $36,3 \mathrm{~mm}$, 35,4m e 35,7m de água no solo, adotou-se $35 \mathrm{~mm}$ de àgua disponível. Para 42,6m de armazenamento adotou-se 45,0mm, para 63,9 e 62,9 adotou-se 60m de água disponível, para 78,6m e 81,0mm adotou-se $80,0 \mathrm{~mm}$, para 108,7m adotou-se 100,0mm e para 133,9m adotou-se 140,0mm de água disponível. Assim, com base nos valores de armazenamento constante do quadro 4 considerou-se que as quantidades de água disponível de $15 \mathrm{~mm}, 35 \mathrm{~mm}, 45 \mathrm{~mm}, 60 \mathrm{~mm}$, $80 \mathrm{~mm}$, 100m e $140 \mathrm{~mm}$ não representativas das condi ções mais comuns na ārea estudada.

\section{2 - Evapotranspiração potencial}

Os valores dos termos da fórmula de Penman e da evapotranspiração potencial média diāria para cada mês do calendário, em Cachoeiro de Itapemirim, calculados a partir das normais climatológicas, constam do quadro 5 .

Segundo THORNTHWAITE e MATHER. (1955), o uso de dados climatológicos diārios na determinação de condições de seca não garante uma maior precisão do que o uso de dados médios mensáis, sendo preferível uti lizar médias mensais e um: maior número de anos. De acôrdo com VAN BAVEL e WILSON (1952), a experiência tem mostrado que, em trabalhos dessa natureza, é válido calcular-se a evapotranspiração usando normas climatológicas.

\section{3 - Contagem dos dias secos consecutivos}

Para cada quantidade de água disponível foram obtidas 5 diferentes saídas em forma de quadros, num total de 42. Devido ao grande vo lume desses quadros eles não foram transcritos neste trabalho, fazendo-se constar, no apêndice, somente aqueles referentes a 35m de água disponí- 


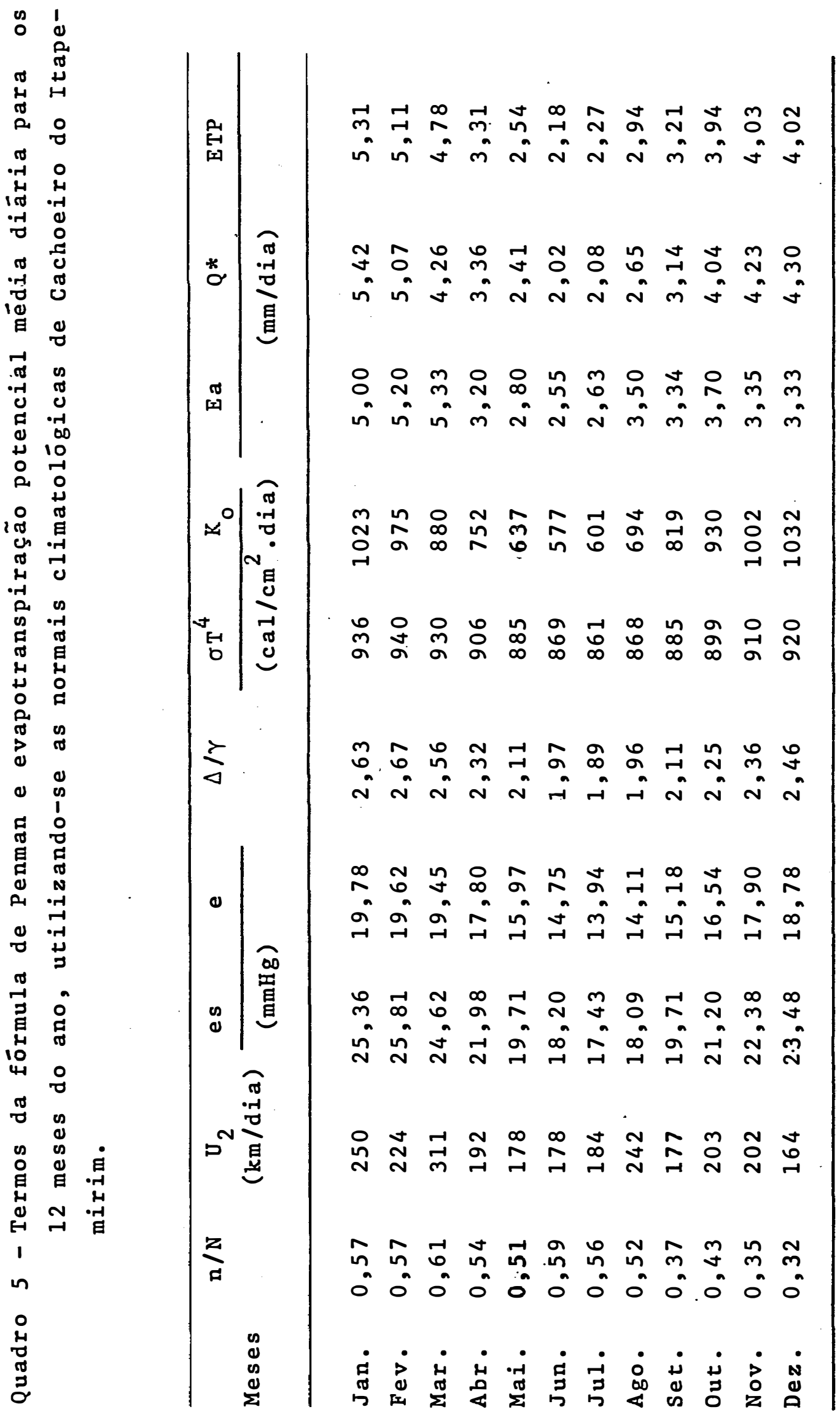


vel, a título de exemplo e para maior facilidade de compreensão do traba 1ho. Para cada quantidade de água disponível foram obtidas as seguintes saỉdas (veja apêndice, para 35mm de àgua disponíve1):

a) Períodos de dias secos consecutivos por ano em ordem de ocorrência. Por exemplo, para 35m de água disponível, no ano de 1941, ob. teve-se: $1,6,14,8,15,45,6,7,9,8,6,1,4,1$, isto é, ocorreram 15 períodos de dias secos consecutivos, sendo que o primeiro período foi de 1 (um) dia seco, o segundo foi de 6 dias secos consecutivos, o tercei ro de 14 dias secos consecutivos e assim por diante (apêndice 1).

b) Totais de dias secos por mês e por ano (apêndice 2). Es te quadro foi obtido com a finalidade principal de se fazer uma verificação adicional nos resultados dos demais quadros, já que o número total de dias secos deveria ser o mesmo em todos os quadros.

c) Frequência (f) ou número de períodos de 1 a 31 dias secos consecutivos por mês do calendário, nos 37 anos estudados (apêndice 3) Por exemplo, para 35m de āgua no solo, no mês de janeiro, is to é, nos 37 janeiros, ocorreram 11 períodos de 1 (um) dia seco, 10 períodos de 2 dias secos consecutivos, 7 de 3 dias secos consecutivos, e assim por diante.

d) Frequência ou número de períodos de 1 a 92 dias secos consecutivos por trimestre, nos 37 anos (apêndice 4). Este quadro é inter pretado de modo semelhante ao do apêndice 3 , citado no item anterior.

e) Dias secos consecutivos agrupados nas classes zero,1-3, $4-6,7-9,10-12,13-15,16-18,19-21,22-24,25-27$ e 28 - 31, suas frequências, frequências relativas e frequências relativas acu muladas (apêndice 5). Os quadros do apêndice 5 foram obtidos com a finalidade de se determinar qual o número mínimo de dias secos consecutivos que se espera ocorrer, a um dado nível de probabilidade, em cada mês do calendário, para cada quantidade de água disponível. Ou ainda, qual a pro babilidade de ocorrer, em cada mês e para cada quantidade de água disponí ve1, um determinado número mínimo de dias secos consecutivos.

E preciso atentar para o fato de que a soma das frequências de todas as classes foi sempre igual a 37, correspondendo aos 37 anos estudados, ou 37 vezes cada um dos meses do calendārio. Isto significa que um determinado mês, num ano, só foi computado uma vêz, mesmo que contives 
se mais de uma sequência com números diferentes de dias secos. Para isso, cada mês foi computado e incluido em uma das 11 classes conforme o número de dias secos de sua maior sequência: Uma vêz contado e incluído em uma das 11 classes, o mês era eliminado. Ainda, um mês que teve duas ou mais sequências iguais e máximas só foi computado uma vêz. Desse modo, se num determinado mês, janeiró, por exemplo, obteve-se uma frequência igual a 7 para a classe de $4-6$, significa que em 7 dos 37 janeiros ocorreu .. pelo menos uma sequência de dias secos nessa classe. Ainda, a ou as maiores se. quências nesses 7 janeiros tiveram de 4 a 6 dias secos. Pode-se então dizer que em 7 dos 37 janeiros ocorreu pelo menos uma sequência máxima de 4 a 6 dias secos. Tomando-se como exemplo o mês de janeiro, no apêndice 5, verifica-se então que dos 37 janeiros do período estudado (37 anos), 4 de les tiveram zero dias secos, em 4 outros ocorreu pelo menos uma sequência máxima de 1 a 3 dias secos, em 7 janeiros teve-se pelo menos uma sequên cia máxima de 4 a 6 dias secos e assim para as demais classes. Na coluna das frequências expressas em porcentagem encontra-se, no mesmo exemplo, que 10,81 dos janeiros não tiveram dia seco, outros 10,81\% tiveram pelo menos uma sequência mäxima com 1 a 3 dias secos, 18,92\% tiveram pelo menos uma sequência máxima na classe de 4 a 6 dias secos e assim para as demais classes. Em termos de Probabilidade pode-se dizer que há uma probabilida de empírica de 10,81\% de ocorrer zero dias secos em janeiro; tembém de $10,81 \%$ de ocorrer pelo menos uma sequência máxima de 1 a 3 dias secos; de $18,92 \%$ de ocorrer pelo menos uma sequência máxima de 4 a 6 dias secos e assim por diante. Ou ainda, dado um número muito grande de janeiros, espe ra-se que em $10,81 \%$ deles não ocorra dia seco; em outros $10,81 \%$ ocorra pe 1o menos uma sequência máxima de 1 a 3 dias secos; em 18,92\% dos janeiros haja pelo menos uma sequência máxima com 4 a 6 dias secos e assim para a demais classes.

A porcentagem acumulada é a probabilidade empírica complementar. Assim, no exemplo anterior, se em $10,8 \%$ dos janeiros não ocorreu dia seco, então, em $100-10,8=89,2 \%$ dọ janeiros ocorreram 1 (um) ou mais dias secos consecutivos ou no mínimo 1 (um) dia seco; se em outros $10,8 \%$ dos janeiros restantes ocorreu pelo menos uma sequência de 1 a 3 dias secos, então, em $89,2-10,8=78,4 \%$ dos 37 janeiros a maior sequência foi maior do que 3 dias secos, ou seja, tiveram 4 ou mais dias secos consecutivos, ou ainda, tiveram no mínimo 4 dias secos consecutivos. E 
ässim sucessivamente para as demais classes. Em termos de probabilidade pode-se dizer que, se há $10,8 \%$ de probabilidade de não ocorrer dia seco, então, há $100-10,8=89,2 \%$ de probäbilidade de ocorrer dia seco ou de ocorrer um ou mais dias secos, ou ainda de ocorrer no mínimo 1 (um) dia seco. Do mesmo modo, há 89,2 - 10,8 = 78,4\% de probabilidade de ocorrer, pelo menos uma vêz, 4 ou mais dias secos consecutivos ou no mínimo 4 dias secos consecutivos. Fazendo-se o mesmo raciocínio para as demais classes verifica-se que as porcentagens acumuladas expressam as probabilidades em píricas de ocorrer, pelo nemos uma vêz, em cada mês do calendārio, um número mínimo de dias secos consecutivos igual ao limite inferior das classes correspondentes. Assim, mo exemplo citado, tem-se: 89,2\% de probabilidade empírica de ocorrer, pelo menos uma vês, no mínimo 1 (um) dia seco;

78,4\% de probabilidade empírica de ocorrer, pelo menos uma vêz, no mínimo 4 dias secos consecutivos;

59,5\% de probabilidade empírica de ocorrer, pelo menos uma vêz, no mínimo 7 dias secos consecutivos;

e assim sucessivamente, para as demais classes, atē o último vàlor de

$2,7 \%$ de probabilidade empírica de ocorrer, pelo menos uma vêz, no mínimo 28 dias secos consecutivos.

\section{4 - Sequências de dias secos anuais, trimestrais e mensais}

Nas contagens de períodos de dias secos consecutivos mensais, trimestrais e anuais, o número total de dias secos encontrado ésem pre o mesmo. Porém, o número de sequências ou períodos de dias secos consecutivos é diferente. Quanto menor o período de contagem, maior serā o número de divisões em duas ou mais sequências menores. Assim, na contagem por período mensais, todas as sequências maiores do que o número de dias do mês, serão divididas, no mínimo, em duas outras menores, bem como todas as sequências que começam em um mês e terminam no mês seguinte. 0 qua dro 6 foi organizado para avaliar-se as diferenças entre as contagens por mês, por trimestre e por ano, em relação ao número total e por classe de sequências e em relação ao número de dias secos em cada classe. A primei ra classe de dias secos consecutivos foi tomada de 1 a 31 dias, de modo 
a englobar todas as sequências mensais e assim facilitar a sua comparação com as contagens por trimestre e por ano. As demais classes dão uma idéia da distribuição das sequências maiores que 31 dias, obtidas nas contagens por trimestre e por ano. Para $15 \mathrm{~mm}$ e $35 \mathrm{~mm}$ de àgua disponível, ocorreu, em cada caso, uma sequência maior do que 71 dias secos, de 75 e 72 dias, res pectivamente, as quais foram incluidas na classe de 62 a 71 . Entretanto, na determinação do número de dias secos referente às frequências ( $f$ ) de cada classe, considerou-se o seu número real de dias secos. 0 número total de dias secos, por ser o mesmo para qualquer período de contagem, foi tomado como base de comparação, determinando-se qual a porcentagem do total de dias secos em cada classe.

0 quadro 6 permite comparar entre si, os resultados obtidos nas contagens por mês, por trimestre e por ano, quanto às frequências ( $f$ ) ou número de sequências em cada classe, quanto ao número de dias secos em ca da classe e quantoà porcentagem do total de dias secos em cada classe. As sim, pode-se verificar, por exemplo, que para 35m de água disponível, ob teve-se, na contagem mensal, um total de 818 sequências com 6.206 dias se $\cos$ e, logicamente, todas as sequências e dias secos na classe de 1 a 31 dias. Na contagem trimestral obteve-se, nesta mesma classe, 662 sequên cias, com 5.073 dias secos, correspondentes a $81,7 \%$ do total de dias secos e na contagem por ano encontrou-se 602 sequências, com 4.928 dias secos ou $79,4 \%$ do total de dias secos.

Considerando-se todas as quantidades de àgua disponível, verifi ca-se que, na contagem por trimestre, em torno de $82 \%$ dos dias secos estão nas sequências de 1 a 31 dias e na contagem anual, $77 \%$ dos dias secos em média, estão nesta classe de sequências. Então, cerca de $100-77=23 \%$ dos dias secos, que na contagem mensal foram incluidos em sequências de 1 a 31 dias, na verdade fizeram parte de sequências maiores, com até 71 dias secos, distribuidas nas demais classes. Pode-se verificar ainda que, cerca da metade dos dias secos incluídos nas sequências maiores que 31 dias, ocorreram na classe de 32 a 41, sendo pequeno o número de sequências maiores que 41 dias, bem como a porcentagem do total dos dias secos inclu idaş nas mesmas. Comparando-se as contagens por trimestre e por ano, praticamente não houve diferença, para nenhuma quantidade de água disponível, quanto ao tamanho e distribuição das sequências e porcentagem do total dos dias secos em cada classe. Conclui-se então que, mesmo para lugares como 


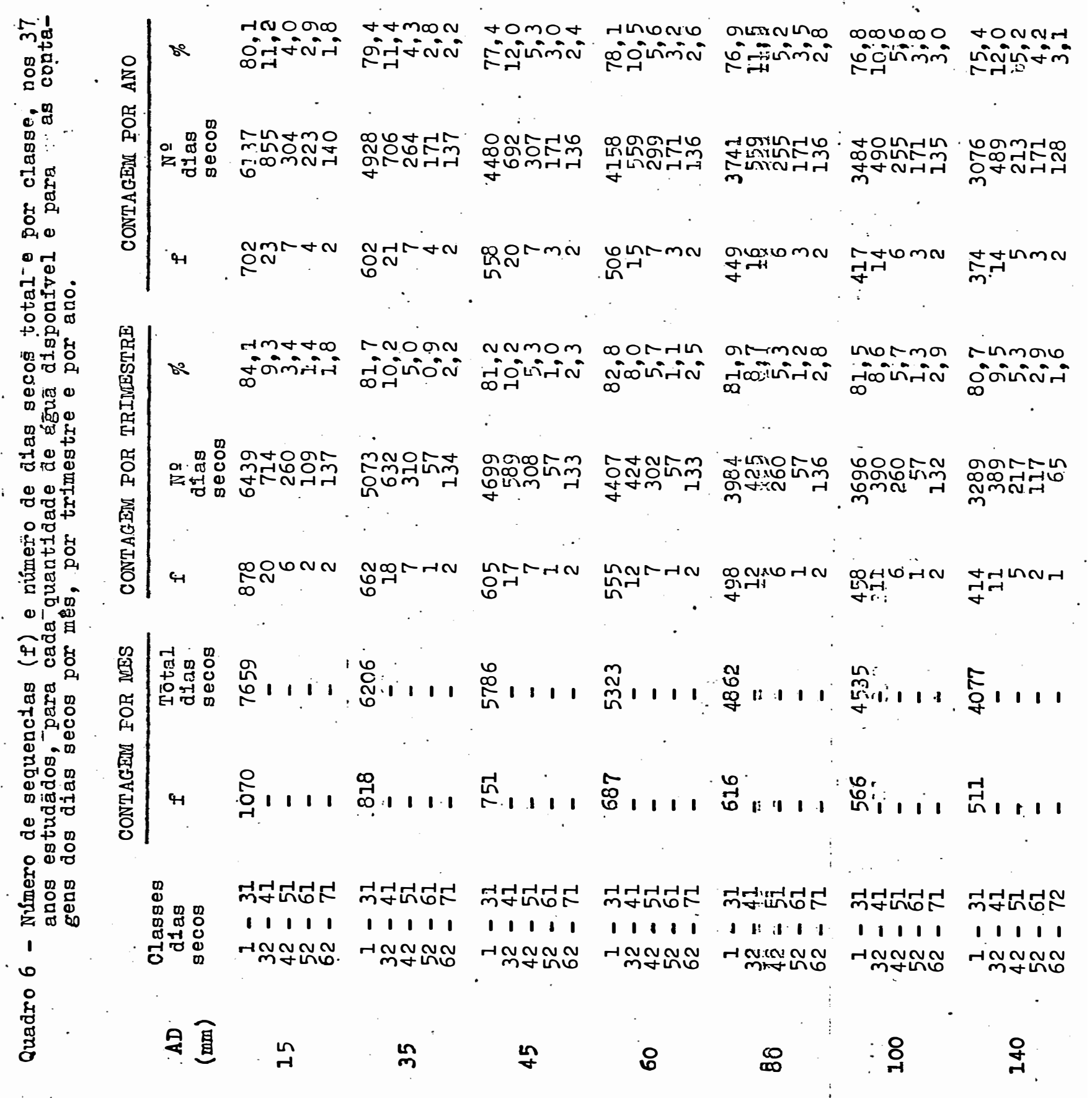


Cachoeiro do Itapemirim, com precipitação anual mal distribuida, além de relativamente escassa, é conveniente se fazer contagens de dias secos con secutivos por períodos de, no máximo três meses, obtendo-se a distribui ção dos períodos secos ao longo do ano, sem cometer erros significativos em relação à contagem anual que nada informa sobre essa distribuição. Em locais onde a precipitação anual tem uma melhor distribuição, as sequên cias de dias secos tendem a ser menores. Consequentemente o erro quanto às frequencias e duração dos períodos de dias secos consecutivos também tende a ser menor, em contagens por períodos menores, como uㅡ mês.

E preciso considerar que, à medida que se adota períodos maio res obtēm-se uma melhor informação quanto à ocorrência de sequências de maior duração, porém, perde-se em informação a respeito de como as sequên cias se distribuem ao longo do período. Assim, numa contagem trimestral, fica-se sem saber se uma sequência de 15, 20 ou mesmo 30 dias secos está localizada no início, no meio ou no final do trimestre. Entretanto, perío dos de dias secos consecutivos com essas durações, apesar da precisão apenas satisfatōria, do método adotado, em caracterizar "dia seco", podem ser considerados como secas bastante severas e que terão efeitos diversos, conforme ocorram em uma ou outra fase de desenvolvimento de uma cultura. Por outro lado, as sequências memores que 31 dias são muito mais frequentes. Como se pode ver no quadro 7, para $15 \mathrm{~mm}$ de água disponível, na contagem por período anual, nos 37 anos estudados correram 738 sequências, sen do que 702 delas tiveram de 1 a 31 dias secos.

Com base nessas considerações, julgou-se mais significativo analisar com mais detalhe a ocorrência de períodos de dias secos consecutivos por períodos mensais.

$\bar{A}$ medida que se considerou maiores quantidades de água disponível no solo, o número total de dias secos, nos 37 anos estudados decresceu. Essa relação era esperada, jā que, para maiores quantidades de água disponível, mais raramente ocorrem chuvas suficientes para completar o armazenamento do solo. Assim, espera-se que, para uma quantidade de $\bar{a}-$ gua disponível acima de um determinado valor, o número total de dias se$\cos$ não mais variará, sendo uma função somente da quantidade e distribuição da precipitação.

Para a ārea estudada encontrou-se uma relação logarítmica entre o número total de dias secos e a quantidade de água disponível no 
solo, representada pelo gráfico da figura 6 e dada pela equação:

$$
\begin{aligned}
& \mathrm{Y}=11968,45-1613,601 \mathrm{nX} \\
& \mathrm{r}^{2}=0,998 \div *
\end{aligned}
$$

onde, Y é o número total de dias secos nos 37 anos, X é a quantidade de água disponível no solo e $\mathrm{r}^{2}$ é o coeficiente de determinação da equação, significativo ao nível de $1 \%$ de probabilidade.

5.5 - Distribuição de probabilidade da variável "número mínimo de dias secos consecutivos mensais"

MORETI (1965), trabalhando com número mínimo de dias secos mensais, sem considerar se sua ocorrência se deu em dias isolados ou em sequências, verificou que sua distribuição de probabilidades se ajustou bem à curva normal. No presente caso, em que se considerou os períodos de dias secos consecutivos mensais, empregou-se um método simples para testas se também as probabilidades dos números mínimos de dias secos consecutivos mensais se ajustavam à distribuição normal. Baseou-se em que, a curva normal se transforma numa reta quando traçada em papel de probabili dade, ou seja, quanto mais perfeito o ajustamento da distribuição de probabilidades de uma variável à curva normal, melhor se ajusta uma reta ao conjunto de pontos quando marcados em papel de probabilidade. Para uma me 1hor compreensão do procedimento adotado, descrito nos itens seguintes, incluiu-se um exemplo referente ao mệs de janeiro e $35 \mathrm{~mm}$ de àgua disponível, cujos valores das probabilidades e respectivos números mínimos de dias secos consecutivos constam do apêndice 5 .

a) Utilizando-se papel de probabilidade e uma régua milimetrada, junto e paralela ao eixo das ordenadas do pepel, como indica a figura 7, foram obtidos, na escala linear da régua, os valores equivalentes aos das probabilidades de ocorrência dos números mínimos de dias : secos consecutivos. Esses valores e os números mínimos de dias secos consecutivos correspondentes formaram um novo conjunto de pares de valores. Para o mês de janeiro e 35m de água disponível os valores das probabilidades (P) e os correspondentes valores ns escala linear (P1) e dos números míni mos de dias secos consecutivos (N) foram: 


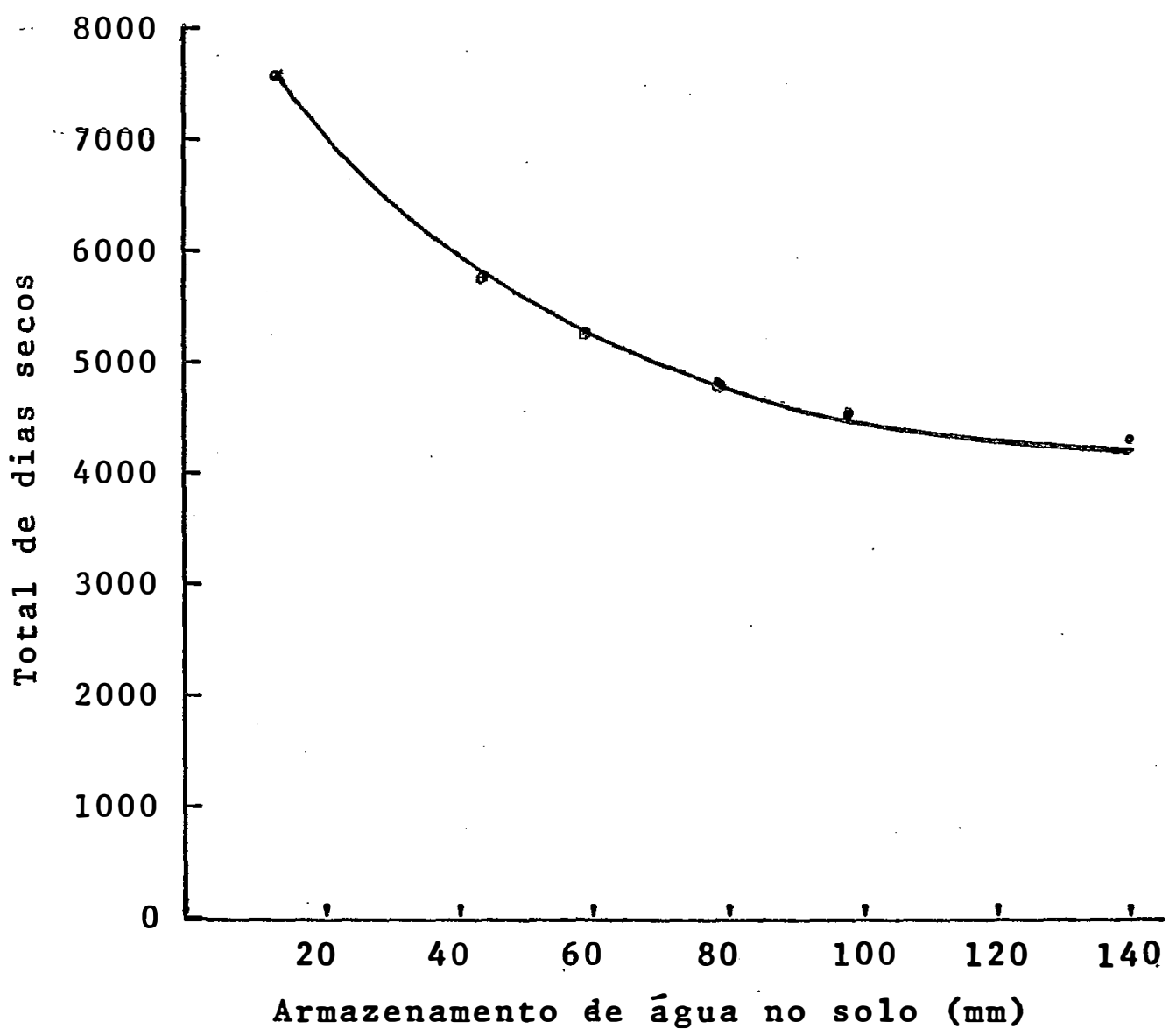

Figura 6 - Variação do número total de dias secos no pe ríodo de 37 anos para as diferentes quantida des de àgua disponível consideradas. 


\begin{tabular}{crr}
\multicolumn{1}{c}{$\mathrm{P}$} & \multicolumn{1}{c}{$\mathrm{PL}$} & $\mathrm{N}$ \\
89,19 & 12,3 & 1 \\
78,38 & 10,8 & 4 \\
59,46 & 8,8 & 7 \\
54,05 & 8,4 & 10 \\
37,84 & 6,8 & 13 \\
21,62 & 5,1 & 16 \\
13,51 & 4,0 & 19 \\
5,41 & 2,4 & 22 \\
5,41 & 2,4 & 25 \\
2,70 & 1,3 & 28
\end{tabular}

b) Se as probabilidades dos nümeros mínimos de dias secos consecutivos se ajustam à curva normal, os valores de P1 e N se correla cionam segundo a equação de uma reta e seu coeficiente de determinação $\left(r^{2}\right)$ pode ser tomado como uma medida do ajustamento das probabilidades dos números mínimos de dias secos consecutivos à curva normal. Para o exemplo citado, a equação obtida pelo método dos mínimos quadrados e seu coeficiente de determinação foram:

$$
\begin{aligned}
& \mathrm{P} 1=12,23-0,41 \mathrm{~N} \\
& \mathrm{r}^{2}=0,98
\end{aligned}
$$

No quadro 7 estão os valores dos coeficientes de determinação dạg equações das retas referentes a cada mês e cada quantidade de água disponível. O seu valor médio foi de 0,96, com desvio padrão de 2,67 e coeficiente de variação de $2,7 \%$. Considerados os respectivos graus de 1 iberdade, todos foram significativos ao nível de $5 \%$ de probabilidade. Medi ante os altos valores encontrados para os coeficientes $r^{2}$, julgou-se desnecessário utilizar uma método estatístico mais apropriado para se testar a distribuição normal dos dados.

Dando a $\mathrm{N}$ os valores $\mathrm{N}=7$ e $\mathrm{N}=20$, na equação acima, obtem-se $\mathrm{P} 1=9,36$ e $\mathrm{P} 1=4,03$, respectivamente. Pelo processo inverso ao indicado no item $\underline{\text { a }}$, utilizando-se novamente a figura 7 , foram encontrados os valores das probabilidades (P) correspondentes a esses valores de P1, obtendo-se, $\mathrm{P}=64 \%$ e $\mathrm{P}=13 \%$, respectivamente. Assim, tem-se, para $\mathrm{N}=7$ 
Quadro 7 - Valores dos coeficientes de determinação ( ${ }^{2}$ ) das equações $P 1=b \pm a N$, onde $\underline{N}$ é o número mínimo de dias secos consecutivos observado e $\underline{P I}$ é a proba-

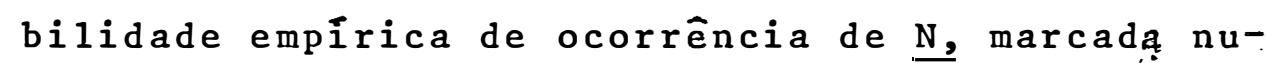
ma escala linear, paralela à escala do papel de probabilidade.

\begin{tabular}{llllllll}
\hline MÊS & $15 \mathrm{~mm}$ & $35 \mathrm{~mm}$ & $45 \mathrm{~mm}$ & $60 \mathrm{~mm}$ & $80 \mathrm{~mm}$ & $100 \mathrm{~mm}$ & $140 \mathrm{~mm}$ \\
\hline & & & & & & & \\
Jan & 0,96 & 0,98 & 0,98 & 0,96 & 0,92 & 0,90 & 0,96 \\
Fev & 0,96 & 0,95 & 0,93 & 0,97 & 0,98 & 0,97 & 0,98 \\
Mar & 0,97 & 0,97 & 0,97 & 0,97 & 0,98 & 0,98 & 0,99 \\
Abr & 0,96 & 0,98 & 0,98 & 0,99 & 0,99 & 0,99 & 0,99 \\
Mai & 0,97 & 0,99 & 0,99 & 0,99 & 0,98 & 0,96 & 0,96 \\
Jun & 0,95 & 0,97 & 0,98 & 0,99 & 0,99 & 0,98 & 0,98 \\
Jul & 0,98 & 0,98 & 0,95 & 0,99 & 0,97 & 0,98 & 0,98 \\
Ago & 0,98 & 0,98 & 0,99 & 0,99 & 0,99 & 0,98 & 0,99 \\
Set & 0,95 & 0,99 & 0,98 & 0,99 & 0,98 & 0,99 & 0,98 \\
Out & 0,96 & 0,95 & 0,96 & 0,96 & 0,96 & 0,96 & 0,97 \\
Nov & 0,94 & 0,89 & 0,91 & 0,86 & 0,99 & 0,95 & 0,99 \\
Dez & 0,96 & 0,91 & 0,96 & 0,92 & 0,99 & 0,90 & 0,92 \\
\hline
\end{tabular}




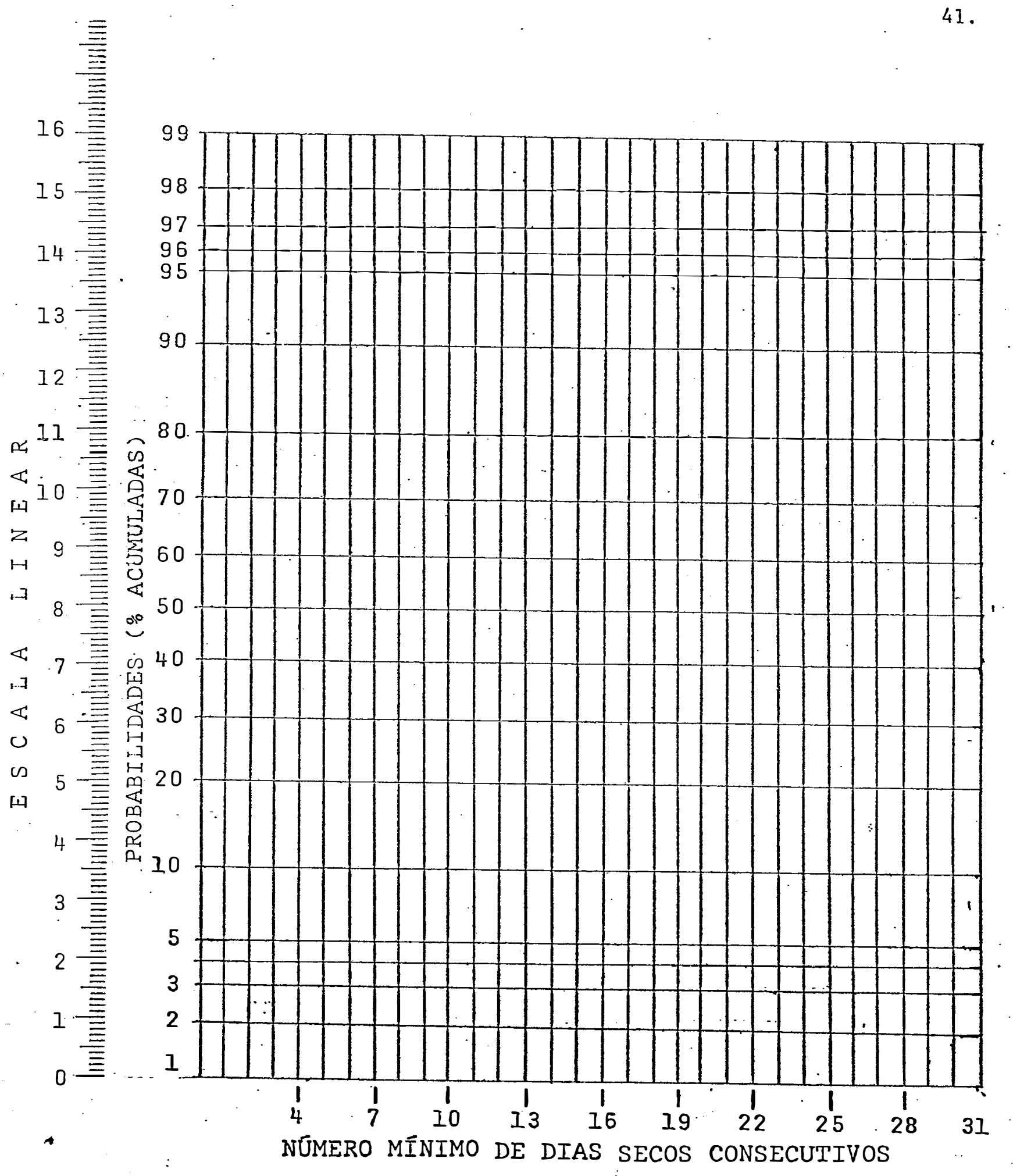

Figura 7 - Marcação dos números mínimos de dias secos consecutivos e suas probabilïdades empíricas de ocorrên cia, em papel de probabilidade e obtenção dos valores correspondentes às probabilidades, em escala li near. 
$\mathrm{P}=64 \%$ e para $\mathrm{N}=20 \mathrm{P}=13 \%$. Por esses dois pontos de coordenadas $(\mathrm{P} ; \mathrm{N})$, $(64 ; 7)$ e $(13 ; 20)$, foi traçada a reta que melhor se ajusta aos pontos marcados em papel de probabilidade, referente ao mês de janeiro e $35 \mathrm{~mm}$ de água disponíve1, na figura 9. 0 mesmo procedimento foi adotado para o traçado das demais retas das figuras 8 a 14 , tendo-se, no eixo das ordenadas (a esquerda), as probabilidades teóricas de ocorrer, pelo menos uma vêz , èm cada mês e para cada quantidade de àgua disponíve1, os nūmeros mínimos de dias secos consecutivos indicados nas abscissas.

0 traçado das retas das figuras 8 a 14 por apenas dois pontos, obtidos das respectivas equações, evitou a necessidade de se -marcartodos os pontos, o que é difícil de ser feito em grä́icos reduzidos. Ainda, conseguiu-se uma precisão que não seria alcançada pelo ajustamento visual das retas aos pontos márcádos.

Os grä́ficos das figuras 15 a 21 foram traçados a partir de dados obtidos das retas das figuras 8 a 14, Neles estão indicados, para ca da quantidade de água disponível, o número mínimo de dias secos consecutivos esperados, pelo menos uma vêz em cada mês, aos níveis de $5 \%, 10 \%, 20 \%$, $30 \%$, $40 \%$ e $50 \%$ de probabilidade.

Os gráficos das figuras 8 a 21 constituiram a forma que se julgou a mais explícita e sintetizada de expor os resultados obtidos e con ter as informações de maior significado.

Nas figuras 8 a 14 referentes às quantidades de 15 $\mathrm{mm}$, 35m $\mathrm{mm}$,

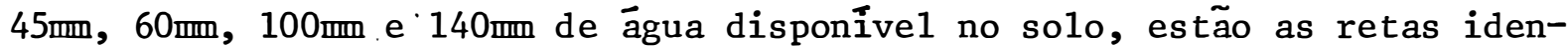
tificadas pèlos números de 1 a 12 , correspondentes aos 12 meses do calendá rio. Alguma dúvida que porventura tenha restado com respeito à sua interpretação, poderá ser esclarecida mediạte o exemplo seguinte: Seja a reta número 1, correspondente, portanto, ao mês de janeiro, para 15m de água disponível (fig.8). Verifica-se que para 10 dias secos (nas abscissas) tem -se, no eixo das ordenadas à esquerda, uma probabilidade de 57\%. Então, tem-se para o mês de janeiro e 155m de água disponível:

a) $57 \%$ de probabilidade teórica de ocorrer pelo menos uma sequência igual ou maior que 10 dias secos, ou,

b) $57 \%$ de probabilidade teórica de ocorrer pelo menos uma sequência de, no mínimo 10 dias secos, ou ainda,

c) $57 \%$ de probabilidade teórica de ocorrer, pelo menos uma vêz no mínimo 10 dias secos consecutivos. 
E fácil verificar que as interpretações acima (letras $\underline{a}$ b e c) são equivalentes, podendo ser usadas indistintamente na interpreta ção das figuras 8 a 14 .

Para as sequências de 16 ou mais dias secos não tem sentido dizer-se "pelo menos" ou "pelo menos uma vêz" ao interpretar as probalili dades de sua ocorrência, jā que é impossível ocorrer mais de uma sequên cia de 16 ou mais dias secos num mesmo mês. Sequências de 15 dias secos só podem ter ocorrido duas vezes num mesmo mês nos meses de 31 dias e nos casos em que, exatamente o dia 16 e só ele não foi "seco". Parece pouco provāvel que sequências com até 10 ou mais dias secos tenham se repetido num mesmo mês. Se houve repetições deverá ter sido com uma frequência mui to baixa. Ainda, considerando o método adotado para a caracterização de "um dia seco", pode-se admitir que sequências menores que 10 dias secos não correspondem a uma condição de seca de severidade significativa. A di visão das sequências menores do que 10 dias em vārias classes foi adotada com a finalidade principal de se obter um maior número de pontos e consequentemente uma maior precisão no traçado das retas das figuras 8 a 14 e não por considerar essa divisão importante na detecção de secas com essas durações. Desse modo, sem cometer erro significativo, pode-se despresar as expressões "pelo menos" e "pelo menos uma vêz" na interpretação das retas das figuras 8 e 14. Então, no exemplo anterior, para o mês de janeiro e $15 \mathrm{~mm}$ de água disponível, ao invés das interpretações dadas nas letras a, $\underline{b}$ e $\underline{c}$, pode-se dizer que se tem:

a) $57 \%$ de probabilidade teórica de ocorrer uma sequência igual ou maior que 10 dias secos, ou,

b) $57 \%$ de probabilidade teórica de ocorrer uma sequência de, no mínimo 10 dias secos, ou ainda,

c) $57 \%$ de probabilidade teórica de ocorrer no mínimo 10 dias secos consecutivos.

Nos eixos de ordenadas à direita encontra-se uma escala de probabilidade igual e invertida em relação ao eixo à esquerda, a qual se refere às probabilidades complementares, ou seja: tem-se $100-57=43 \%$ de probabilidade teórica de ocorrer uma sequência menor que 10 dias secos,ou de ocorrer uma sequência de no máximo. 9 dias secos, ou ainda de ocorrer no máximo 9 dias secos consecutivos. 
Os gräficos das figuras 15 a 21 foram traçados a partir de valores obtidos das retas das figuras 8 a 14 e por isso estão sujeitos às mesmas considerações a respeito da repetição e significado das sequências menores que 10 dias secos. Admitidas como válidas essas considerações, os grä́ficos das figuras. 15 a 21 dão, como ordenadas, o número mínimo de dias secos consecutivos esperados em cada mês do calendārio, aos níveis de pro babilidade de $5 \%, 10 \%, 20 \%, 30 \%, 40 \%$ e 50\%. Esses gräficos evidenciam as épocas mais secas ao longo do ano e permitem identificar facilmente os me ses mais secos do ano.

Como era de se esperar, as secas são menos frequentes e menos severas à medida que aumenta a quantidade de āgua disponível no solo. Porēm, a ārea estudada está sujeita a secas bastante severas, mesmo para a quantidade de 140 mon de água disponível no solo. Apenas os meses de novembro podem ser considerados ter bom suprimento de água, como se pode ver pelos gráficos das figuras 8 a 21. Nesses meses, mesmo quando o solo só armazena 15mm de água disponível, existe uma probabilidade de apenas $5 \%$ de ocorrer uma sequência maior que 14 e 18 dias secos, respectivamente. Os meses mais secos são fevereiro, junho, julho, agosto e setembro. Nesses meses tem-se sempre uma probabilidade acima de $50 \%$ de ocorrerem 10 ou mais dias secos consecutivos, para até 60m de água disponível no solo.

Considerando-se um risco de $10 \%$ como e uma sequência de 10 dias secos ou mais como correspondendo a uma condição de seca significativa, verifica-se que, na ārea estudada, mesmo para 140m de água disponí vel, há ocorrêncià de seca em todos os meses do ano, exceto em novembro e dezembro. Sequências de 20 ou mais dias secos são esperadas ocorrer em 4 meses do ano em $10 \%$ dos casos, para 140m de àgua disponível.

E preciso considerar que os dias secos consecutivos esperados foram determinados por estrapolação das condições ocorridas em um período de tempo limitado no passado e nada pode assegurar que, no futuro, as condições passadas se darão de modo semelhante. Entretanto, neste caso, a melhor estimativa do que pode ocorrer no futuro é obtida por extrapolação das condições no passado. 


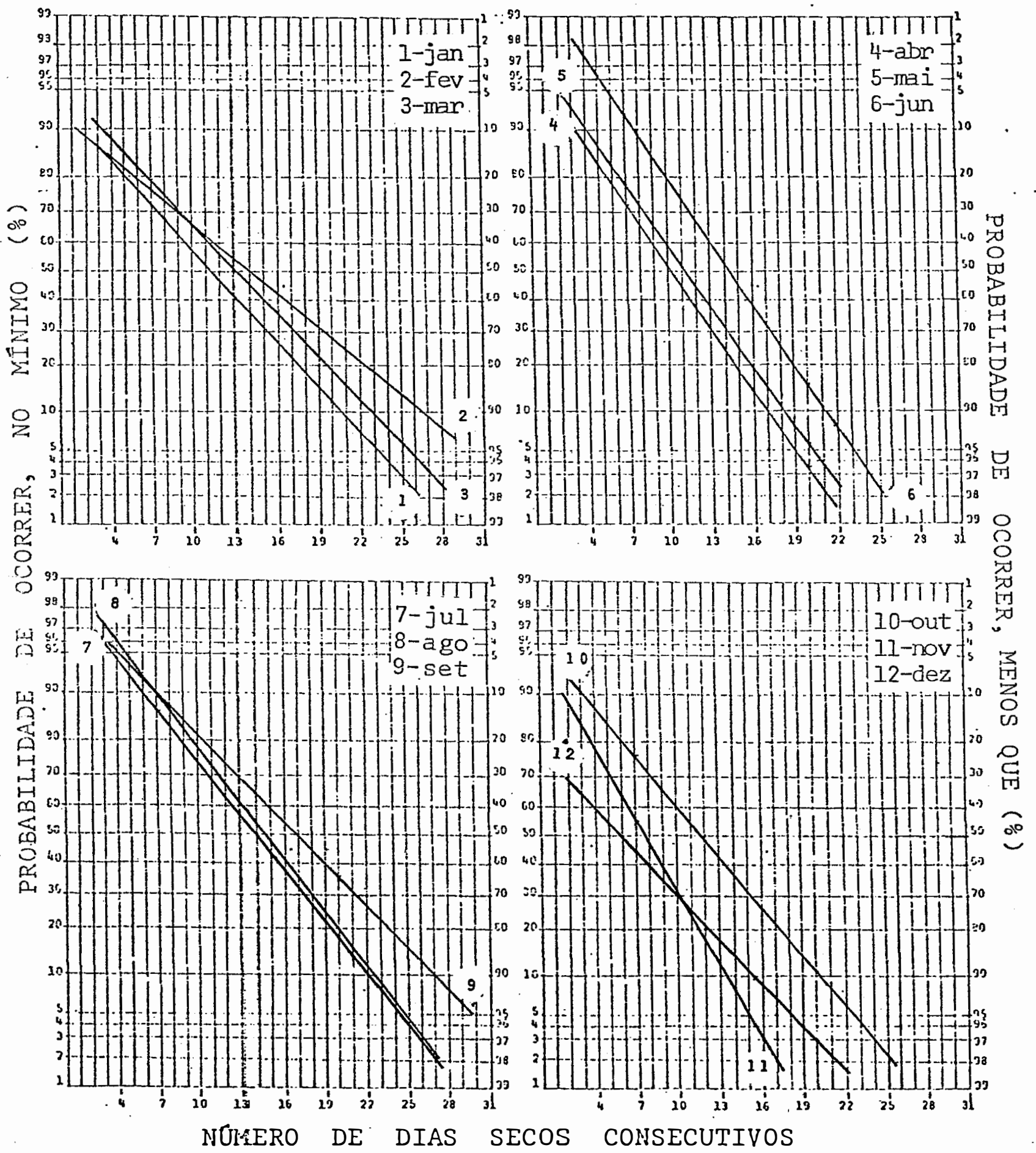

Figura 8 - Probabilidades teóricas de ocorrer, um dado número mínimo de dias secos consecutivos, para $15 \mathrm{~mm}$ de água disponível, para càda mês. 


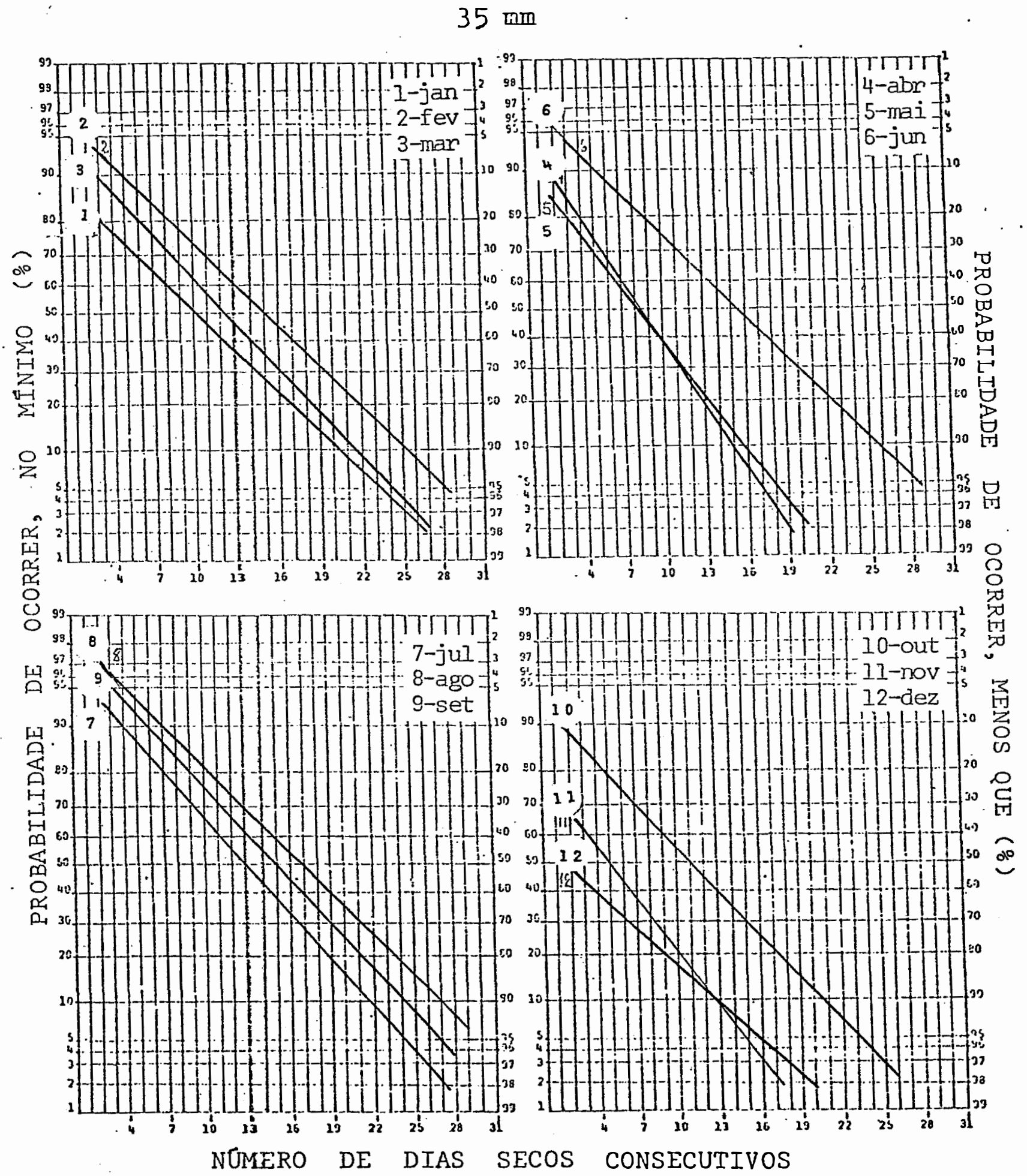

Figura 9 - Probabilidades téóricas de ocorrer, um dado número mínimo de dias secos consecutivos, para $35 \mathrm{~mm}$ de àgua disponível, para cada mês. 


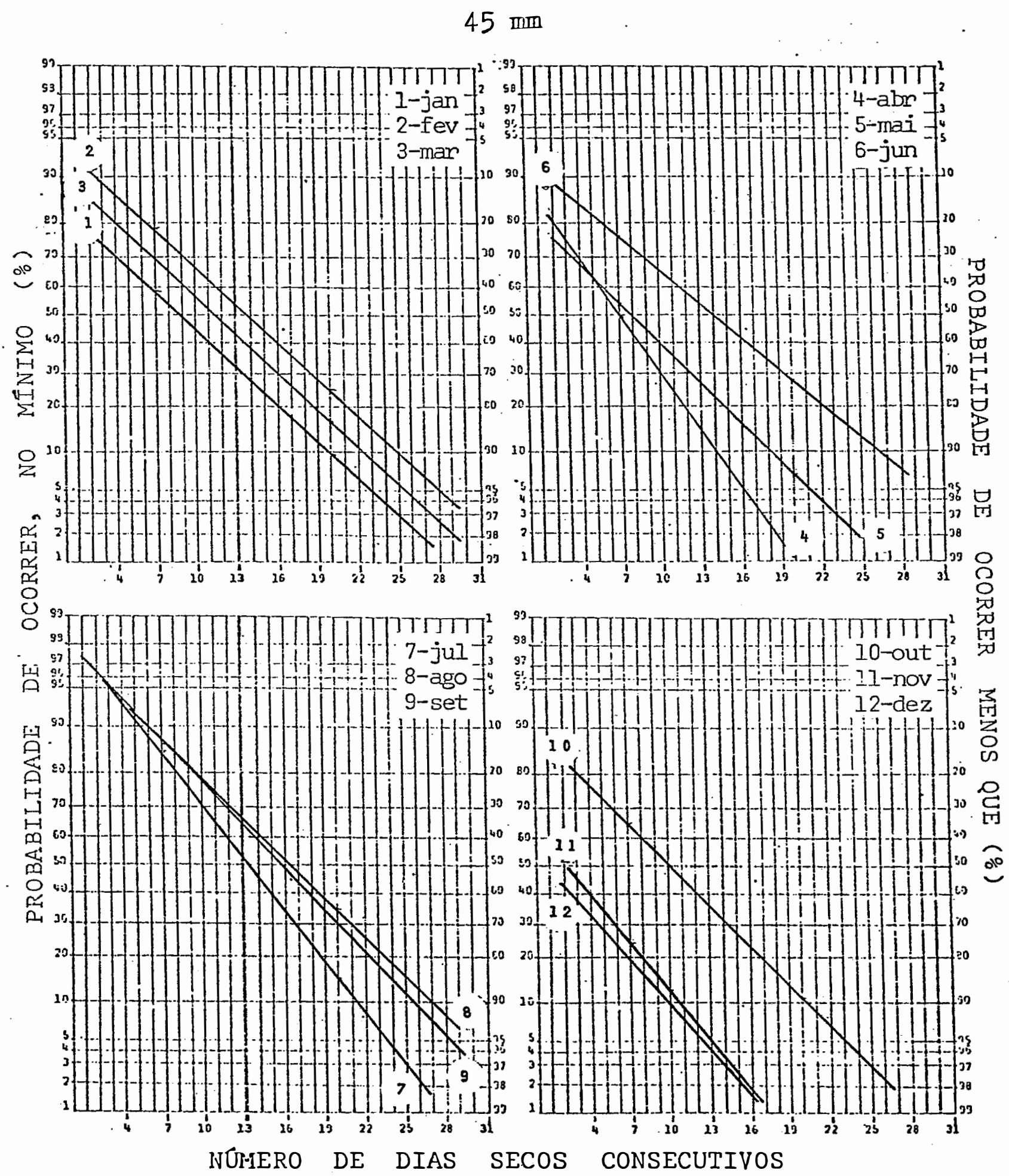

Figura 10 - Probabilidades teóricas de ocorrer, um dado número mínimo de dias secos consecutivos, para $45 \mathrm{~mm}$ de água disponível, para cada mês. 


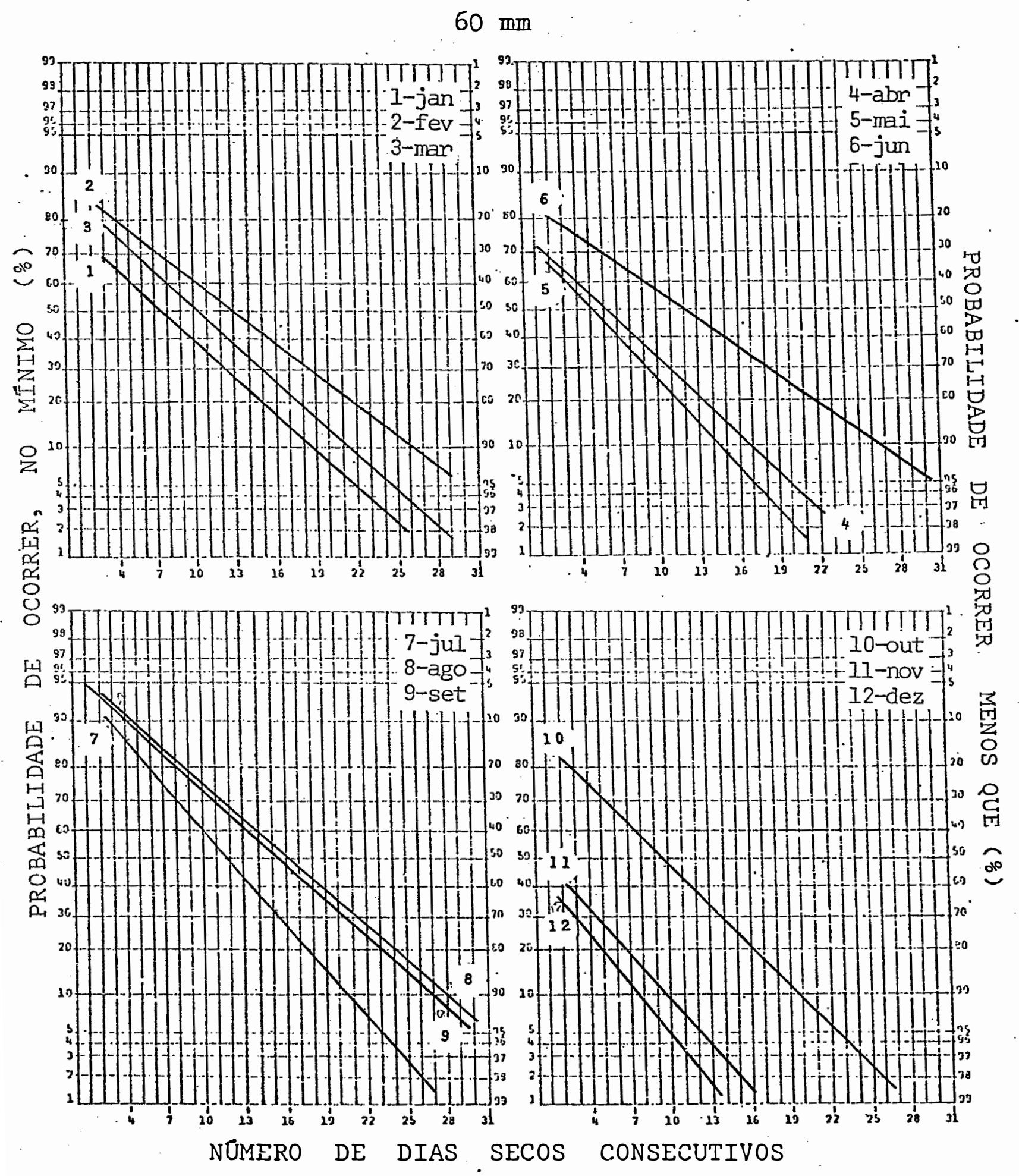

Figura 11 - Probabilidades teóricas de ocorrer, um dado número mínimo de dias secos consecutivos, para $60 \mathrm{~mm}$ de àgua disponível, para cada mês. 


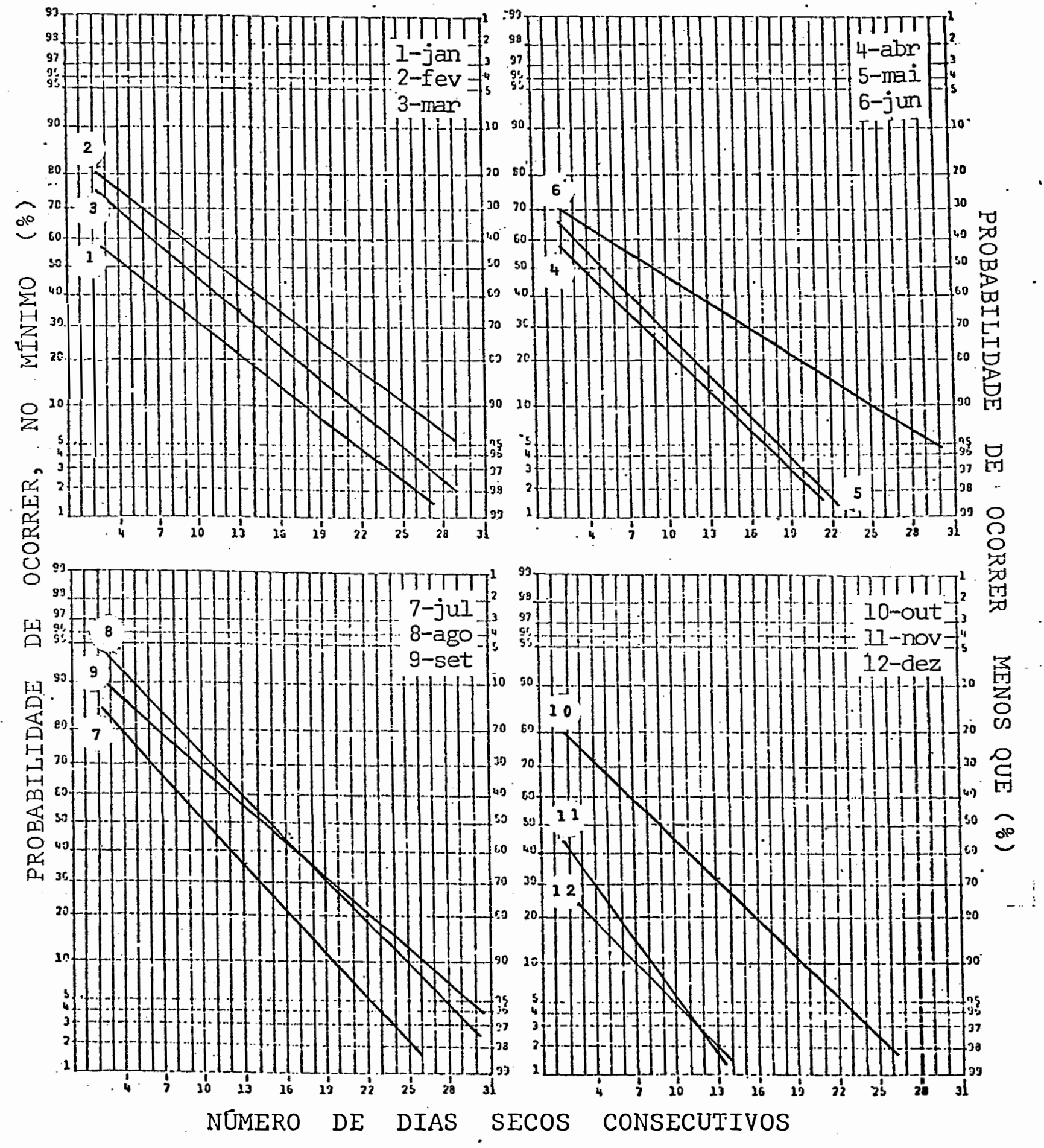

Figura 12 - Probabilidades teóricas de ocorrer, um dado número mínimo de dias secos consecutivos, para $80 \mathrm{~mm}$ de água disponível, para cada mês. 


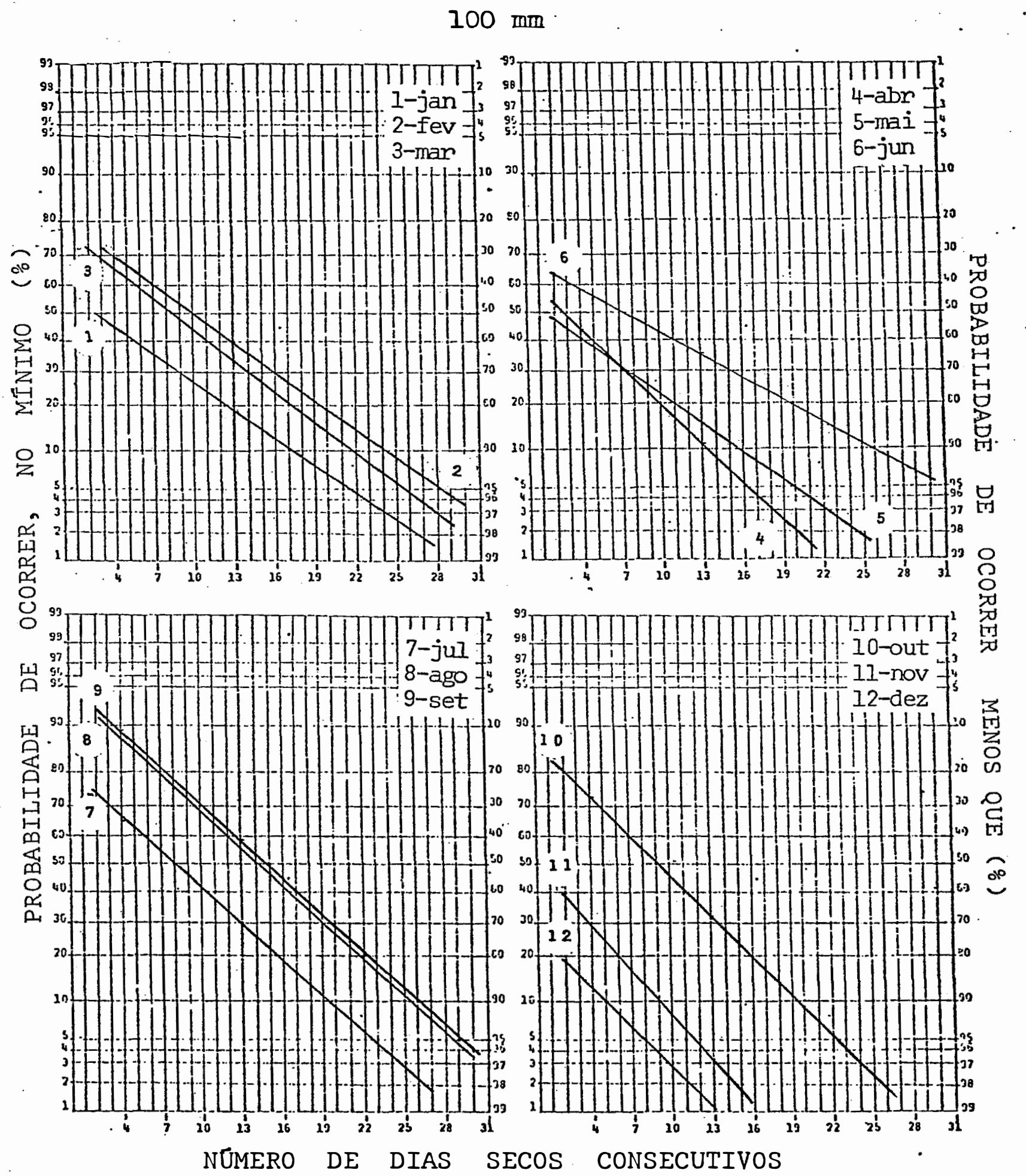

Figura 13 - Probabilidades teóricas de ocorrer, um dado número mínimo dè dias secos consecutivos, para $100 \mathrm{~mm}$ de água disponível,para cada mês. 


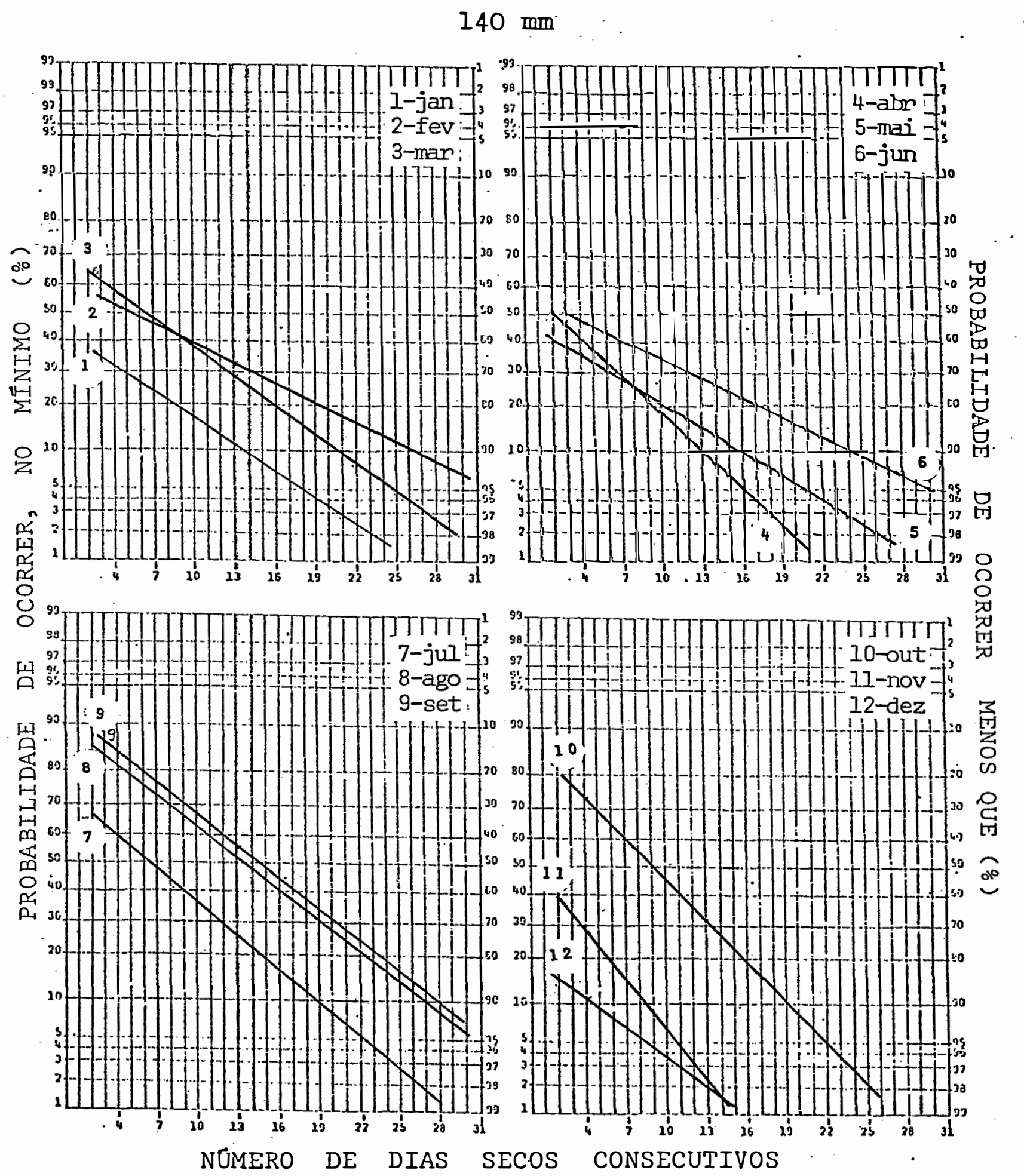

Figura 14 - Probabilidades teóricas de ocorrer, um dado número mínimo de dias secos consecutivos, para 140 m de àgua disponível, para cada mês. 


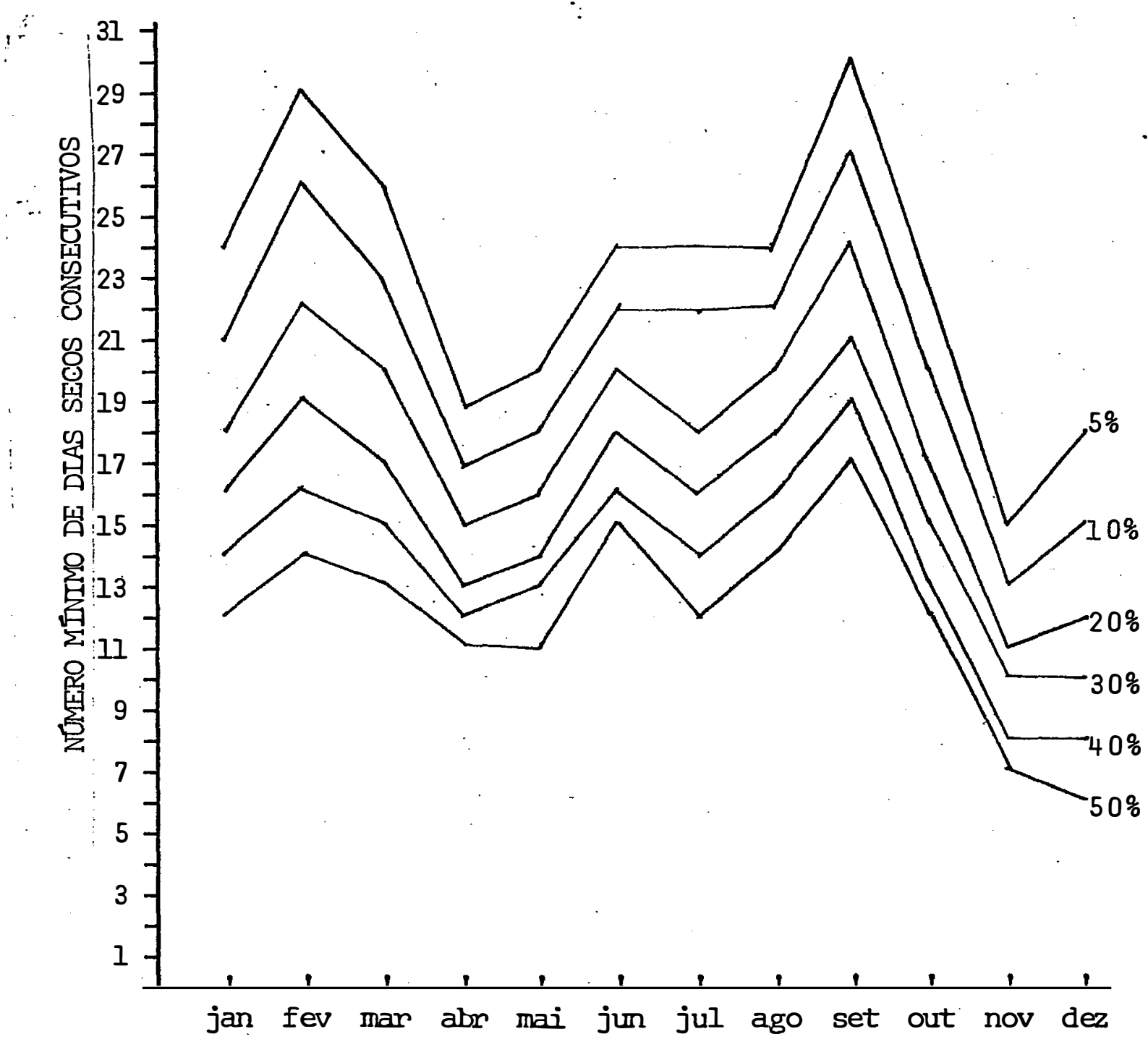

Figura hís - Número minimo de dias secos consecutivos esperados, em cada mês do calendārio, aos !ñíveis de $5 \%, 10 \%, 20 \%, 30 \%$, $40 \%$ e $50 \%$ de probabilidade. 


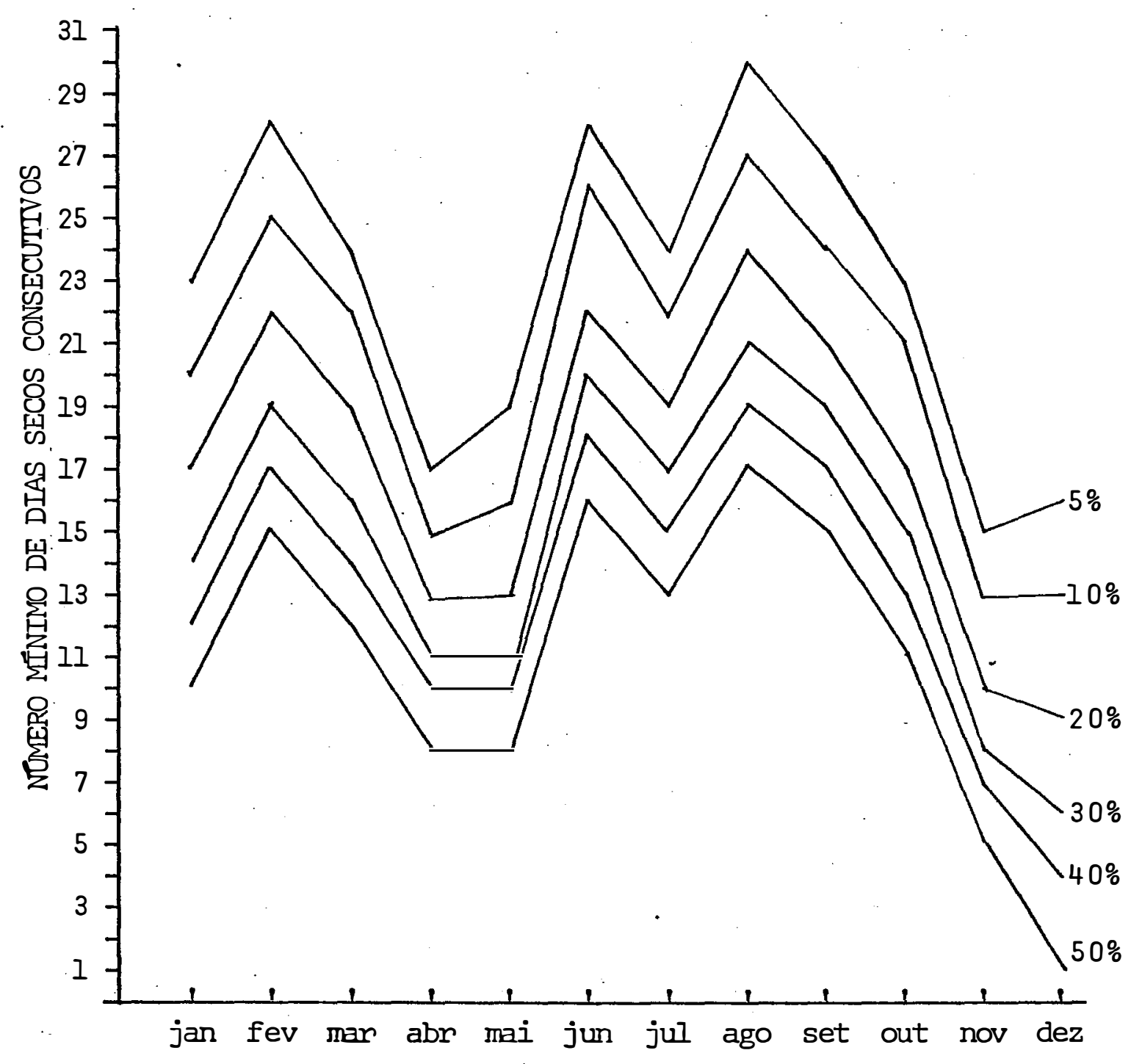

Figura 16 - Nümero minnimo de dias secos consecutivos esperados, em cada mês do calendário, aos nỉveis de $5 \%$, $10 \%, 20 \%, 30 \%$, $40 \%$ e $50 \%$ de probabilidade. 


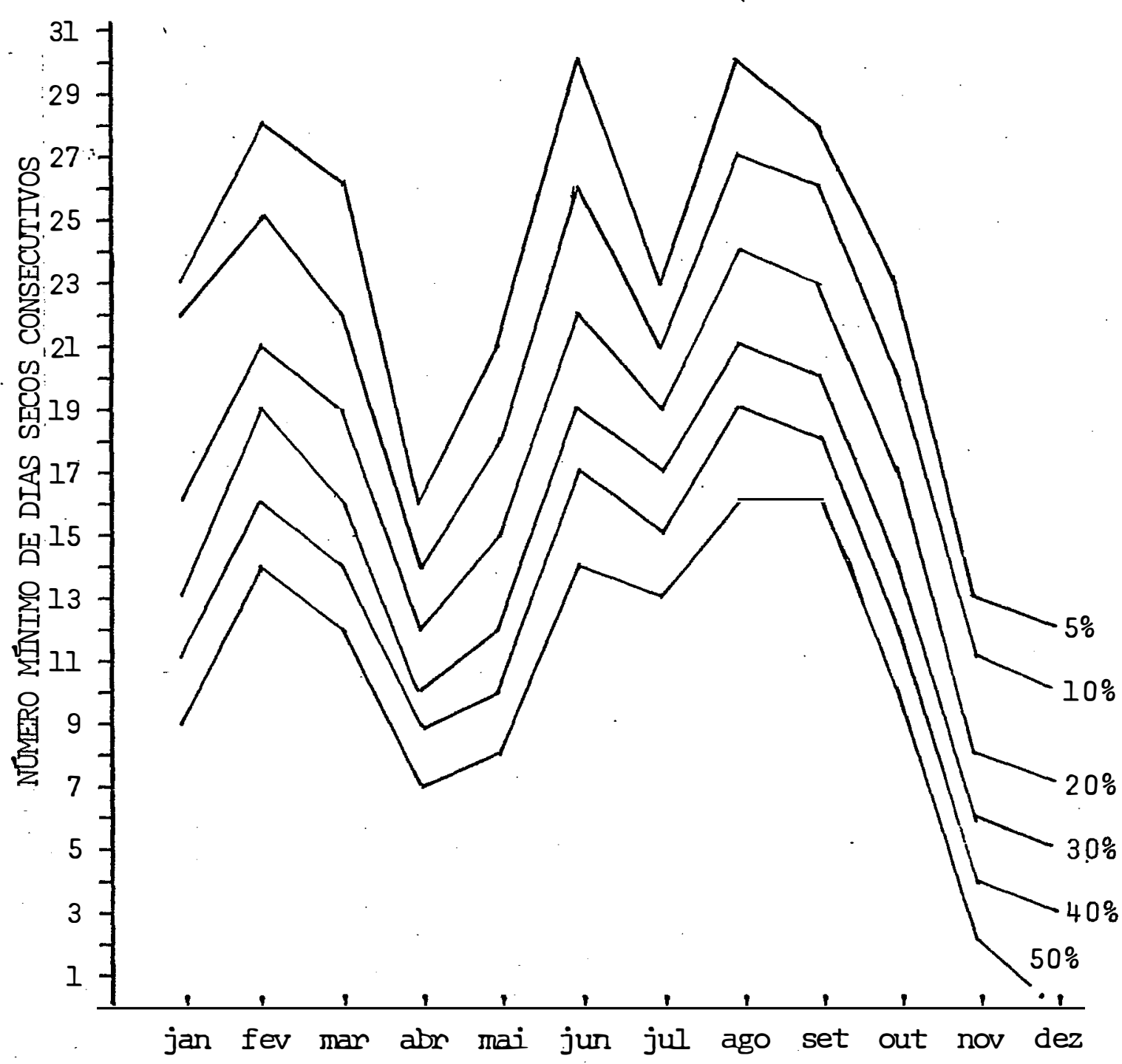

Figura 17 - Nümero mínimo de dias secos consecutivos esperados, em cada mês do calendário, aos nỉveis de probabilidade de 5\%, $10 \%, 20 \%, 30 \%, 40 \%$ e $50 \%$. 
$60 \mathrm{~mm}$

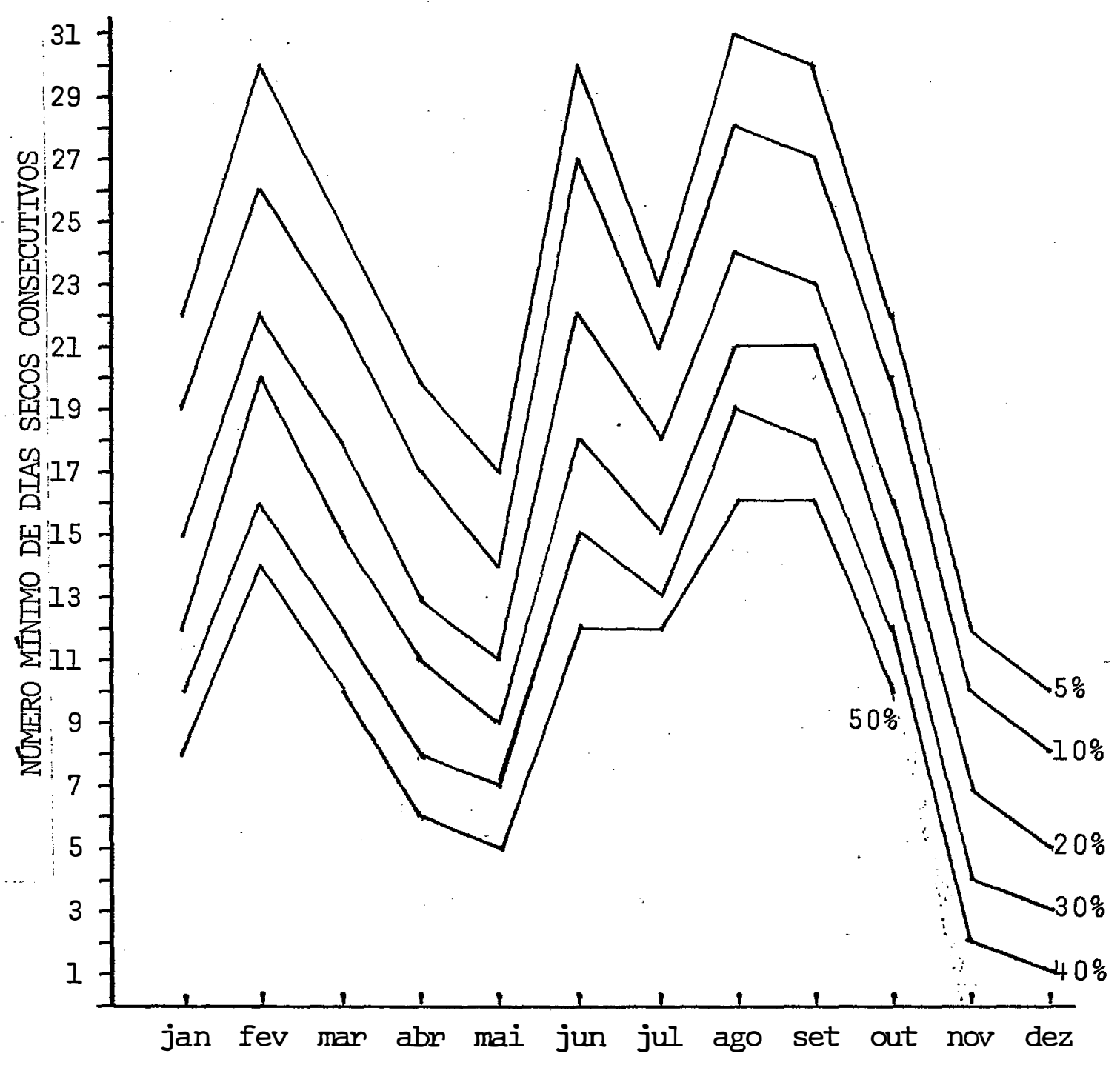

Figura 18 - Número mínimo de dias secos consecutivos esperados, em cada mês do calendário, aos. 'níveis de probabilidade de $5 \%, 10 \%, 20 \%, 30 \%, 40 \%$ : e $50 \%$. 
$80 \mathrm{~mm}$

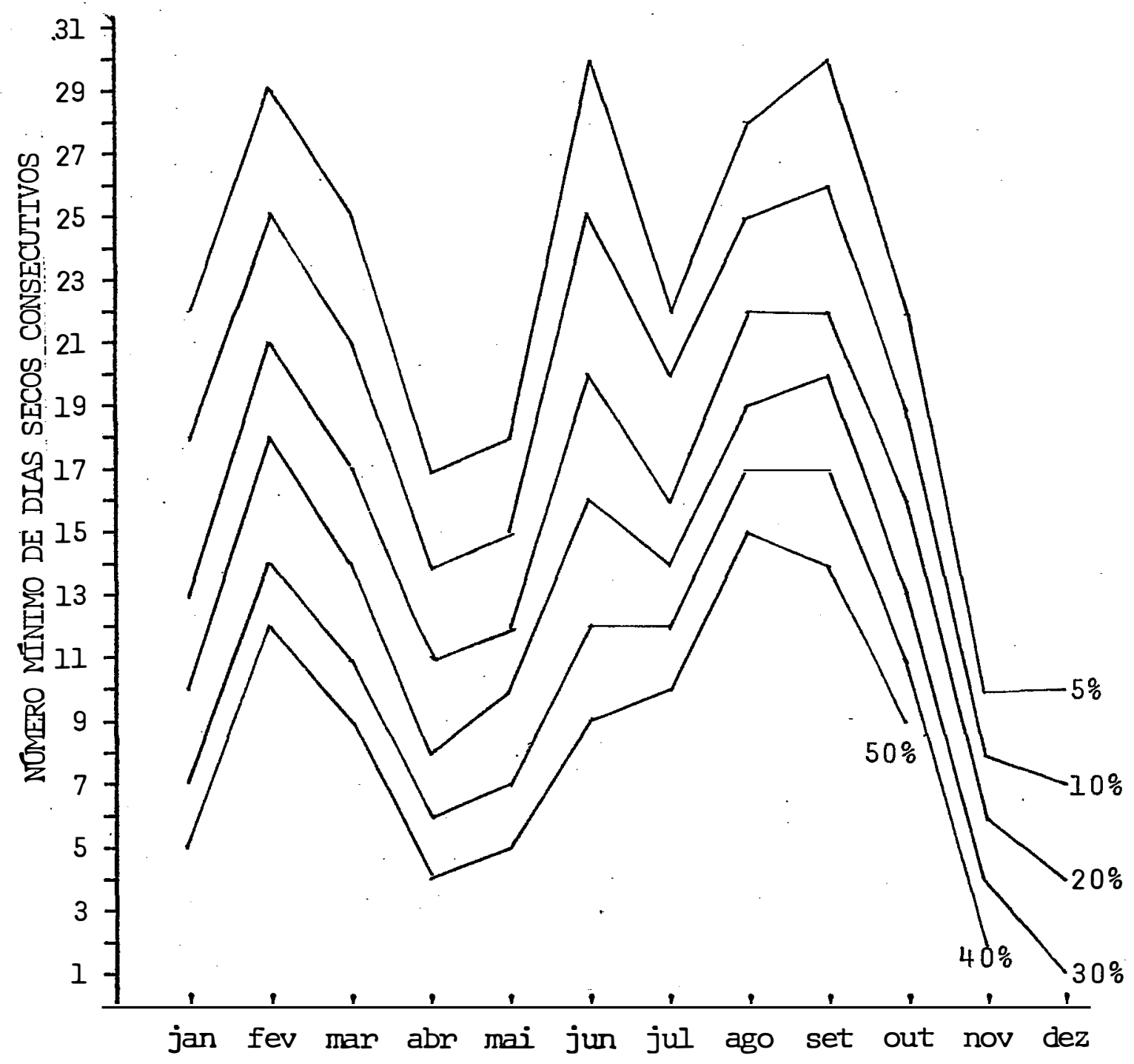

Figura 19 - Número mínimo de dias secos consecutivos esperados em cada mês do calendário, aos níveis de probabilidade de $5 \%, 10 \%, 20 \%, 30 \%, 40 \%$ e $50 \%$. 
$\because$

$100 \mathrm{~mm}$

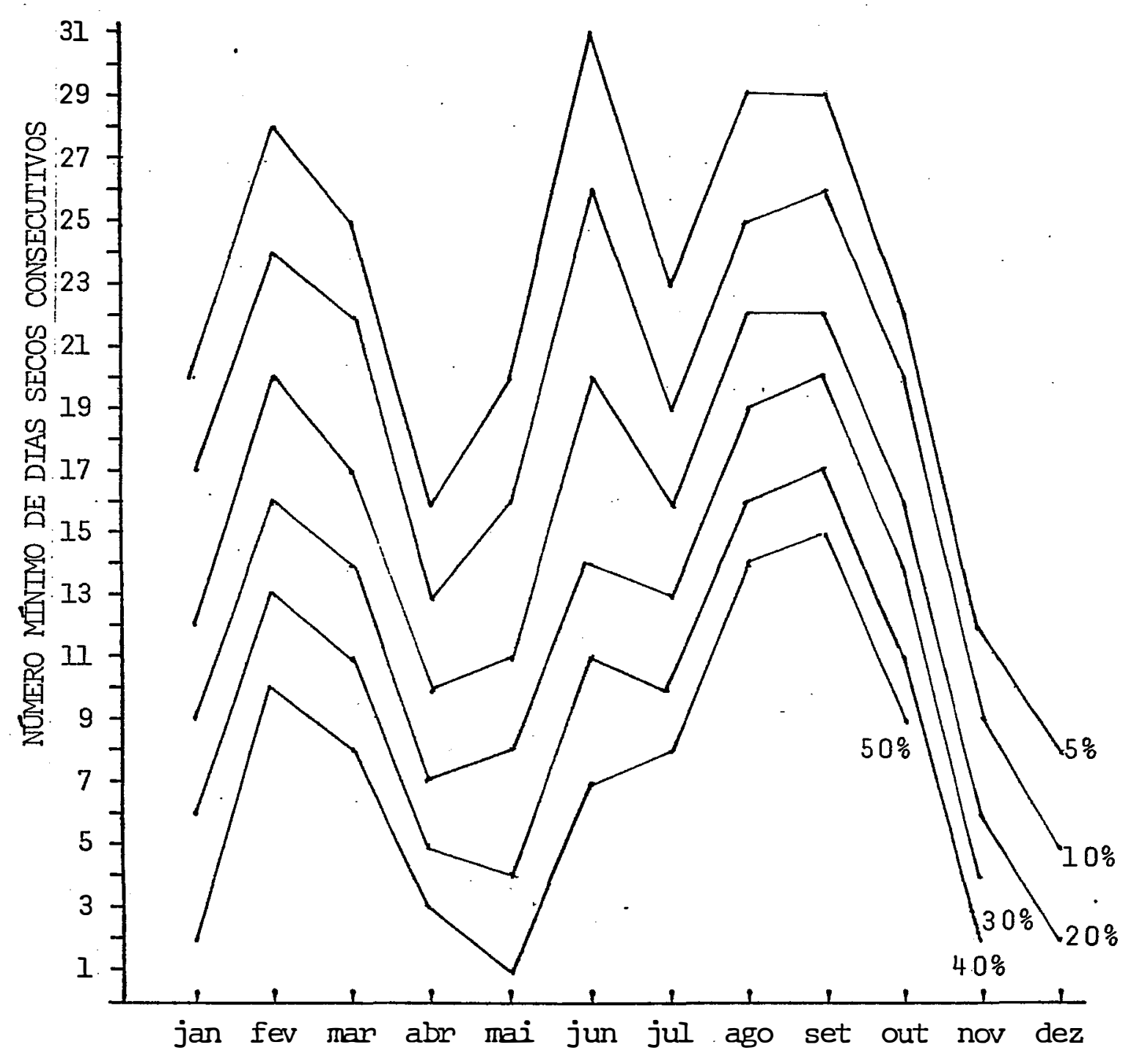

Figura 20 - Número mínimo de dias secos consecutivos esperados em cada mês do calendário, aos níveis de probabilidade de $5 \%, 10 \%, 20 \%, 30 \%, 40 \%$ e $50 \%$ : 
$140 \mathrm{~mm}$

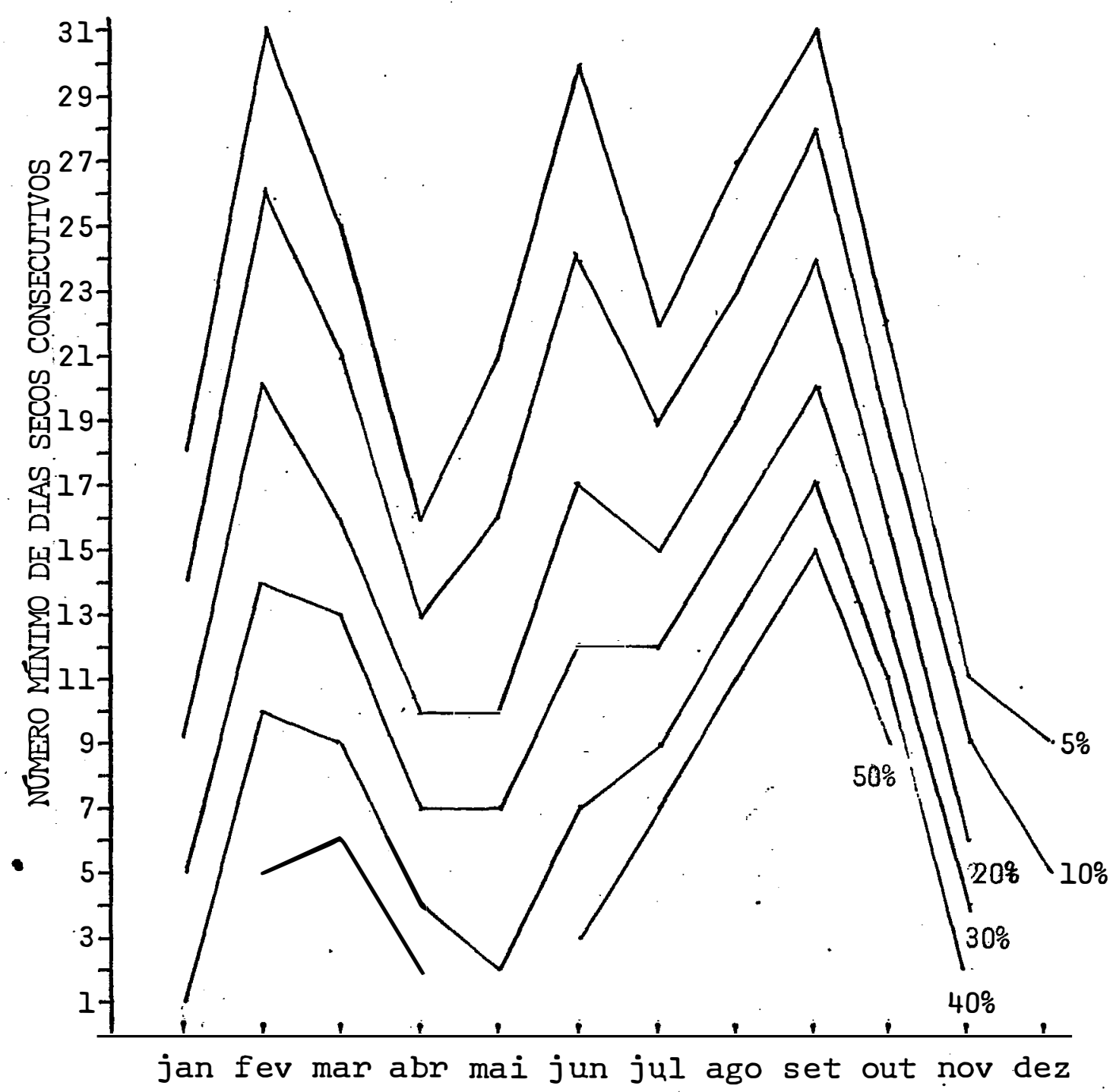

Figura 21 - Número mínimo de dias.secos consecutivos esperados, em cada mês do calendārio, aos níveis de $5 \%$; $10 \%, 20 \%$, $30 \%$, $40 \%$ e $50 \%$ de probabilidade. 
6. CONCLUSÕES

Pelos resultados obtidos pode-se concluir que:

a) $\mathrm{Na}$ computação dos períodos de dias secos consecutivos por mês, cerca de $20 \%$ do total de dias secos, incluidos em sequências de 1 a 31 dias, na verdade ocorreram em sequências maiores que 31 dias, obtidas na computa ção por período anual. Porém não se obteve diferença apreciável quanto ao número e duração das sequências nas contagens por trimestre e por ano. Esse fato sugere que, para locais com chuvas mais bem distribui ${ }_{i}$ das do que a ārea estudada, pode-se fazer a contagem por períodos menores do que três meses sem êrro apreciāvel, obtendo-se um maior detalhamento da distribuição dos períodos secos ao longo do ano:

b) 0 número total de dias secos, nos 37 anos estudados, decresceu com o au mento da quantidade de água disponível no solo segundo uma curva logarîtmica.

c) Nas computações de dias secos consecutivos por mês, por trimestre e por ano, quanto menor a sequência de dias secos maior a sua frequência,prin cipalmente nos meses mais chuvosos, para todas as quantidades de água disponível. Assim, a maior frequência foi de 1 (um) dia seco, seguida 
60.

da de dois dias secos e assim por diante.

d) A distribuição de probabilidades do número mínimo de dias secos conse cutivos mensal se ajustou à curva normal.

e) Nos meses mais chuvosos, de dezembro, janeiro, novembro, maío e outubro, mais de $46 \%$ das sequências foram de 1 a 4 dias secos e mais de $22 \%$ delas foram de 5 a 9 dias secos. Nos meses restantes, mais de $23 \%$ das sequências foram de 1 a 4 dias secos e mais de $15 \%$ delas tive ram de 5 a 9 dias secos.

f) Considerando-se um risco de $10 \%$ e uma sequência de 10 ou mais dias se cos como uma condição de seca significativa, verifica-se ocorrência de seca na ārea em todos os meses do ano, exceto em novembro e dezembro, mesmo para $140 \mathrm{~mm}$ de água disponível.

g) Para $140 \mathrm{~mm}$ de água disponível, períodos de 20 ou mais dias secos con secutivos são esperados em 2 meses do ano em 30\% dos anos, em 3 meses do ano em $20 \%$ dos anos e em 4 meses do ano em $10 \%$ dos anos.

Para até $60 \mathrm{~mm}$ de àgua disponível, sequências de 20 ou mais dias secos são esperadas em 7 meses do ano, em $10 \%$ dos anos. Sequências de 10 ou mais dias secos são esperadas em 11 meses do ano em $10 \%$ dos anos.

h) Dada a, frequência e severidade com que ocorrem deficiências de āgua no solo na região de Cachoeiro do Itapemirim, pode-se considerar que essas deficiências se constituem no principal fator responsável pelas baixas médias de produtividade dessa região. Assim sendo, a prática da irrigação, nessa e outras regiões climaticamente semelhantes do Es tado do Espírito Santo, deverá se revelar altamente vantajosa. 
7. SUMMARY

Drought occurences were studied in a southern area of the State of Espirito Santo, which is climatically represented by the records obtained in Cachoeiro do Itapemirim meteorological station. Drought was measured as "drought-days sequences" and the drought-days were defined by the climatological soil moisture budget method, as described by VAN BAVEL (1953) and MORETI (1965), for seven different storage-water figures in the soil (15 mm, $35 \mathrm{~mm}, 45 \mathrm{~mm}, 60 \mathrm{~mm}, 80 \mathrm{~mm}, 100 \mathrm{~mm}$ e $140 \mathrm{~mm}$ ), taking account of different depths and moisture characteristic of two representa tive soils in the area.

With climatological normals of Cachoeiro de Itapemirim, the daily mean potential evapotranspiration in each month was estimated Penman's method and the daily precipitation records of 37 years were used for computations of drought-days sequences for monthly, quarterly and yearly periods.

The number and duration of drought-days sequences computed monthly, quarterly and yearly were compared. It was observed that in a montly computation, about $23 \%$ of the total number of drought-days in the 37 years period, occurred in sequences larger than 31 days. There was 
no remarkable difference between quarterly and yearly computations regarding to the number and duration of drought-days sequences.

It was estimated the empirical probability to occur at least 1 to 28 dry days sequences for each level of soil available water. Since the frequencey distribution conformed with a normal probability cur ve, it was possible to draw, in probit papers, straight lines corresponding to the theoretical probability of occurrence, concerned to those dry days periods. The levels of probability considered in this paper was: $5,10,20,30,40$ and $50 \%$. 
AL-KHAFAF, S. ; P. J. WIERENGA e B. C. WILLIAMS, 1978. Evaporative flux from irrigated cotton as related to leaf area index, soil water and evaporative demand. Agronomy Journal, Washington, 70(6): 912-17.

AMIR, I. ; J. B. ARNOL e W. K. BILANSKI, 1977. A procedure for determining probabilities of dry and wet days. Canadian Agricultural Engineering, Ottawa, 19: 2-5.

BARGER, G. L. e H. C. S. THOM, 1949a. A method for characterizing drought intensity in Iowa. Agronomy Journal, Washington, 41: 13-19.

BARGER, G. L. e H. C. S. THOM, 1949b. Evaluation of drought hazard. Agronomy Journal, Washington, 41(11): 519-26.

BAYER, W., 1965. The interrelationship of meteorological factors, soil moisture and plant growth. International Journal of Biometeorology, Anisterdam, $9(1): 5-20$. 
BEHBOUDIAN, M. H., 1977. Effects of drought on some plant parameters measured at various levels of irridiance and temperature. In: WATER RELATIONS OF CUCUMBER, TOMATO AND SWEET PEPPER. Wageningen, Agri cultural University, 18 p. (Publication no 439).

BEHNKE, J. J. e G. B. MAXEY, 1969. An empirical method for estimating monthly potential evapotranspiration in Nevada. Journal of Hydrology, Amsterdam, 8: 413-30.

BERNARDO, S., 1977. Relação solo-āgua-clima e planta. Boletim de Extensão da Universidade Federal de Viçosa, Viçosa, no 6, 30 p.

BLUMENSTOCK, G., 1942. Drought in the United States analysed by means of the theory of probability. Technical Bulletin of the United States, Department of Agriculture, Washington, no 819, 63 p.

CAMARGO, A. P., 1966. Contribuição para a determinação da evapotranspiração potencial do Estado de São Paulo. Boletim do Instituto Agronômico, Campinas, no 161, 53 p.

DECKER, W. L., 1962. Precision of estimates of evapotranspiration in Missouri climates. Agronomy Journal, Washington, 54: 529-31.

DENMEAD, O. P. e R. H. SHAW, 1962. Availability of soil water to plants as affected by soil moisture and meteorological conditions. Agronomy. Journal, Washington, 54(5): 385-90.

DOORENBOS, J. e W. O. PRUITT, 1975. Crop water requirements. Roma, FAO, 179 p. (Irrigation and drainage paper, no 24). 
EAGLEMAN, J. R. e W. L. DECKER, 1965. The role of soil moisture in eva potranspiration. Agronomy Journa1, Washington, 57: 626-29.

EMPRESA BRASILEIRA DE PESQUUISA AGROPECUÁRIA. Serviço Nacional de Levantamento e Conservação de Solos, Rio de Janeiro, 1978. Levantamento. de reconhecimento dos solos do Estado do Espírito Santo. Rio de Ja neiro, SNLCS , 461 p. (SNLCS - Boletim Técnico, no 45).

FRITSCHEN, L. T. e R. H. SHAW, 1961. Evapotranspiration for corn as re lated to pan evaporation. Agronomy Journal, Washington, 53: 149-50.

GAVANDE, S. A. e S. A. TAYLOR, 1967. Influence of soil, water poten-:

tial and atmosferic evaporative demand on transpiration and the energy status of water in plants. Agronomy Journal, Washington, 59 (1): 4-7.

GORNAT, B. ; D. GOLDBERG e D. SADAN, if1. Changes in the ratio between sugar beet evapotranspiration and pan evaporation during the growing season. Agronomy Journal, Washington, 63: 256-58.

HARGREAVES, G. H., 1974. Precipitation dependability and potential for agricultural production in Northeast Brazil. Logan, Utah State Ini versity, $15 \mathrm{p}$.

HOLMES, R. M. A G. W. ROBERTSON, 1959. A modulated soil moisture buAget. Monthly Weather Review, Washington, 87: 101-6.

ITEM, H., 1974. A model for the water regime in a deciduous forest. Journal of Hydrology, Amsterdam, 21: 201-10.

KING, K. M. e HEER-AMISSAH, A. de, 1967. Potential evapotranspiration at Guelph. In: CANADIAN CONFERENCE ON MICROMETEOROLOGY, 1. Toronto. Toronto, Meteor. Serv. of Canada, Pt. 2, p. 511-27. 
LAWRENCE, E. N., 1957. Estimation of the frequency of runs of dry days (part I). Meteorological Magazine, London, 86(1023): 257-69.

LEHANE, J. J. e W. J. STAPLE, 1953. Water retention and availability in soils related to drought resistance. Canadian Journal of Agricul-. tural Sciences, Ottawa, 33: 265-73.

LEMON, E. R. ; A. H. GLASSER e L. E. SATTERWHITE, 1957. 'Some aspects of the relationship of soil, plant and meteorological factors to evapotranspiration. Proceedings of the Soil Science Society of America, Madison, 21: 464-68.

LETEY, J. e G. B. BLANK, 1961. Influence of environment on the vegetative growth of plants watered at various soil moisture suctions. Agronomy Journa1, Washington, 53: 151-53.

MATHER, J. R., 1954. The determination of soil moisture from climatic data. Bulletin of the American Meteorological Society, Easton, Pa., 35: 63-68.

MEDHI, J., 1976. A Markov chain model for the occurrences of dry and wet days. Indian Journal of Meteorology, Hydrology and Geophysies, New Delhi, 27(4): 431-5.

MILLAR, A. A. e W. R. GARDNER, 1972. Effect of the soil and plant water potentials on the dry matter production of snap beans. Agronomy Journal, Washington, 64(5): 559-62.

MORETI FILHO, J., 1965. Caracterização da seca agronômica na zona canavieira do Estado de São Paulo como base para os estudos de irrigação. Piracicaba, ESALQ/USP, 93 p. (Tese de Livre-Docência).

NANKEN, L. N. ; C. J. GERARD e R. G. BROWN, 1968. Evapotranspiration of cotton and estimation methods. Agronomy Journal, Washington, 60: $4-7$. 
PALMER, W. C., 1965. Meteorological drought. U. S. Department of Commerce, Weather Bureau, Washington, 58 p. (Research Paper no 45).

PARMELE, L. H. e J. L. MCGUINNESS, 1974. Comparisons of musered and estimated daily evapotranspiration in a humid region. Journal of Hydrology, Amssterdam, 22: 239-51.

PELTON, W. L. ; K. M. KING e G. B. TANNER, 1960. An evaluation of Thornthwaite and mean temperature methods for determining potential evapotranspiration. Agronomy Journal, Washington, 52: 387-95.

PENMAN; H. L., 1964. Vegetation and hidrology, Farnham Royal, C.A.B. 123 p. (Techánical communication no 53).

PIERCE, L. T., 1958. Estimating seasonal and short term flutuations in evapotranspiration. Bulletin of the American Meteorological Society, Easton, Pa., 39: 73-8.

PRUITT, W. O. e M. C. JENSEN, 1955. Determining when to irrigate. Agricultural Engineering, St. Joseph, 36(4): 389-93.

RICKARD, D. S., 1957. A comparison between measured and calculated soil moisture deficit. New Zealand Journal of Science and Technology, Sect.. A, We11ington, 38: 1081-90.

RIDER, N. E., 1958. Measurement of evaporation, humidity in the biosphere and soil moisture. Geneva, WMO, 49 p. (Technical note no 21).

RIETVELD, M. R., 1978. A new method for estimating the regression coefficients in the formula relating solar radiation to sunshine. Agricultural Meteorology, Amsterdam, 19: 243-52.

RITCHIE, J. T. A E. BURNETT, 1971. Dryland evaporative flux in a subhumid climate. II - Plant influences. Agronomy Journal, Washing ton, 63: 56-62. 
ROSENBERG, N. J. ; H. E. HART e K. W. BROWN, 1968. Evaporation (Review of Research). Lincoln, Univ. of: Nebraska, 78 p. (Miscellaneous Publications, 20).

SAlATI, E. ; A. CERVELINI ; N. A. VIllA NOVA ; J. C. OMETTO ; J. M. Dos SANTOS e C. R. M. GODOY, 1967. Estimativa da radiação solar que atinge uma ārea horizontal unitāria, admitindo-se a ausência da atmosfera. Rio de Janeiro. Min. da Agricultura, Serviço de Meteorologia Boletim Técnico no 6).

SAXTON, K. E. ; H. P. JOHNSON e R. H. SHAW, 1974. Modeling evapotranspiration and soil moisture. Transactions of ASAE, St. Joseph. 67377.

SCAPOLI, E. J., 1972. Métodos climatológicos para avaliar a evapotrans piração. Piracicaba, ESALQ/USP, 80 p. (Tese de Mestrado).

SCARDUA, R., 1970. Evapotranspiração real da cultura do milho como base aos projetos de irrigação. Piracicaba, ESALQ/USP, 161 p. (Tese de Doutoramento).

SEGUIN, B., 1975. Etude comparée des methodes d'éstimation d'ETP en climat méditerranēe du Sud de la France (Région d'Avignon). Annales. Agronomiques, Paris, 26(6): 671-91.

SILVA, M. M. P. ; M. I. M. DE ARAUJO e A. M. P. A. ANDRADE, 1977. Probabilidade de ocorrência de verânicos na baixada campista. Saneamento, Rio de Janeiro, 51 (1/2): 26-33.

SMITH, G. W., 1959. The determination of soil moisture under a permanent grass cover. Journal of Geophysical Research, Baltimore, 64: 477-83. 
THORNTHWAITE, C. W., 1947. Climate and moisture conservation. Annals of the Association of American Geographers, Washington, 37: 87-100.

THORNTHWAITE, C. W. e J. R. MATHER, 1955. The water budget and its use in irrigation. Yearbook of Agriculture, Washington, 346-57.

TÜRC, L., 1961. Evaluation des besoins en eau d'irrigation et évapotranspiration potentielle. Annales Agronomiques, Paris, 12(1): 13-49. 
70.

9 - A P E N D I C E 


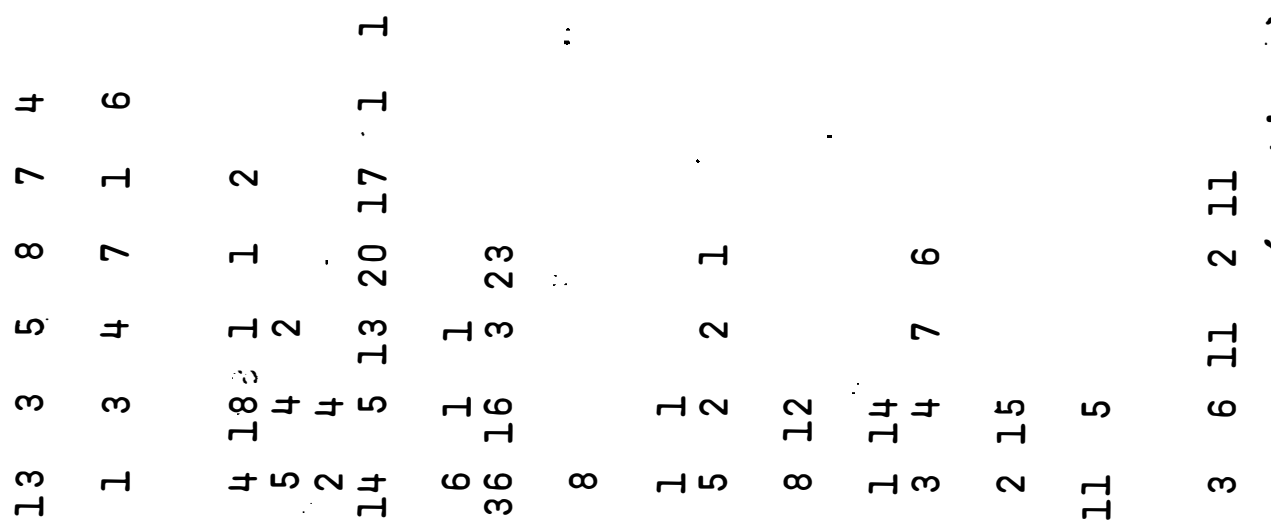

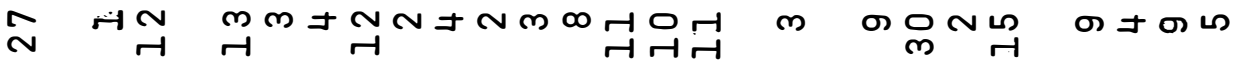

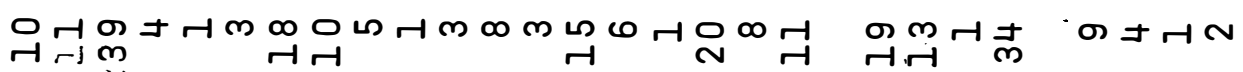
a

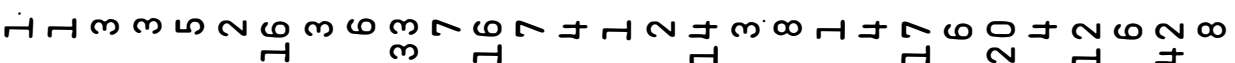
ม $\sim m$ r $m$ N $N$ त

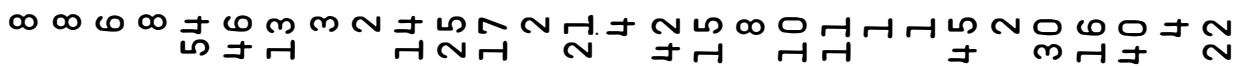
מ

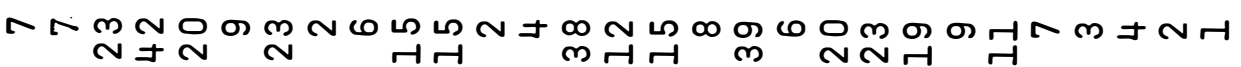
ம HLm J m $m_{m}$ ग mथत्त N $\infty$ N

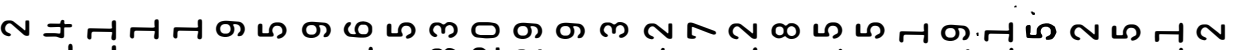

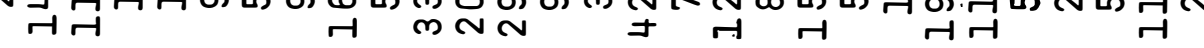
ม H

O HNm

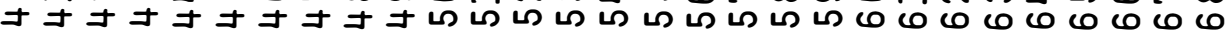

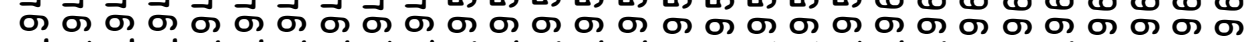

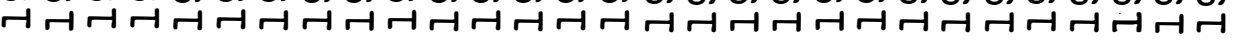




$$
\begin{aligned}
& \text { N } \\
& \infty \\
& \text { - } \\
& \rightarrow N \\
& \text { ก } \\
& \text { n n } \\
& \sim \underset{\sim}{N} N \\
& \text { ต } \\
& \text { न } \\
& \text { त) } \\
& \sim \infty \stackrel{m}{\sim} \sim \\
& \text { मृन्न } \\
& \text { ल ल } \\
& \text { ব } \\
& \text { म } \\
& \text { u } \quad \infty \circ \infty \omega \infty \mathrm{m} \\
& .6 \mathrm{~m}
\end{aligned}
$$

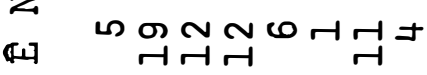

$$
\begin{aligned}
& \text { D N } \\
& \text { ○ न न }
\end{aligned}
$$

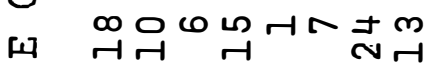

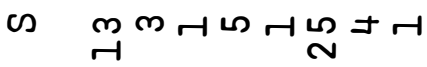

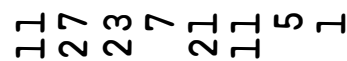

$$
\begin{aligned}
& \text { व } m \text { m } \\
& \text { 개매 }
\end{aligned}
$$

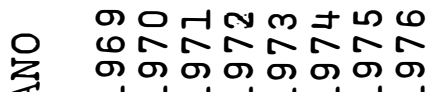

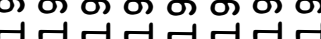


Apêndice 2 - Totais de dias secos por mês e por ano, nos 37 anos, para $35 \mathrm{~mm}$ de água disponịvel no solo.

ANO jan fev mar abr mai jun jul ago set out nov dez totais

$\begin{array}{llllllllllllll}1940 & 12 & 10 & 1 & 19 & 3 & 4 & 18 & 27 & 15 & 5 & 0 & 19 & 133\end{array}$

$\begin{array}{llllllllllllll}1941 & 7 & 14 & 8 & 8 & 7 & 27 & 8 & 25 & 12 & 8 & 11 & 1 & 136\end{array}$

$\begin{array}{llllllllllllll}1942 & 2 & 28 & 25 & 12 & 13 & 25 & 8 & 19 & 25 & 7 & 13 & 1 & 178\end{array}$

$\begin{array}{llllllllllllll}1943 & 6 & 17 & 20 & 11 & 28 & 18 & 8 & 24 & 25 & 14 & 14 & 2 & 187\end{array}$

$\begin{array}{llllllllllllll}1944 & 20 & 2 & 17 & 5 & 0 & 12 & 20 & 25 & 30 & 24 & 0 & 6 & 161\end{array}$

$\begin{array}{llllllllllllll}1945 & 7 & 18 & 10 & 0 & 13 & 30 & 25 & 22 & 20 & 22 & 1 & 3 & 171\end{array}$

$\begin{array}{llllllllllllll}1946 & 19 & 25 & 10 & 1 & 25 & 21 & 28 & 15 & 25 & 18 & 8 & 6 & 201\end{array}$

$\begin{array}{llllllllllllll}1947 & 11 & 19 & 7 & 12 & 11 & 17 & 7 & 14 & 18 & 3 & 4 & 2 & 125\end{array}$

$\begin{array}{llllllllllllll}1948 & 18 & 12 & 16 & 16 & 4 & 20 & 21 & 23 & 26 & 17 & 8 & 0 & 181\end{array}$

$\begin{array}{lrrrrrrrrrrrrr}1949 & 2 & 0 & 19 & 4 & 21 & 14 & 23 & 25 & 25 & 10 & 2 & 0 & 145\end{array}$

$\begin{array}{llllllllllllll}1950 & 13 & 19 & 15 & 9 & 15 & 12 & 16 & 24 & 17 & 16 & 7 & 1 & 164\end{array}$

$\begin{array}{llllllllllllll}1951 & 25 & 21 & 18 & 2 & 18 & 8 & 18 & 15 & 30 & 19 & 23 & 0 & 197\end{array}$

$\begin{array}{llllllllllllll}1952 & 0 & 11 & 17 & 21 & 21 & 27 & 9 & 5 & 8 & 16 & 3 & 0 & 138\end{array}$

$\begin{array}{llllllllllllll}1953 & 25 & 13 & 14 & 8 & 0 & 28 & 28 & 24 & 17 & 20 & 0 & 0 & 177\end{array}$

$\begin{array}{llllllllllllll}1954 & 19 & 22 & 22 & 8 & 3 & 5 & 19 & 19 & 19 & 15 & 21 & 8 & 180\end{array}$

$\begin{array}{llllllllllllll}1955 & 14 & 28 & 26 & 7 & 1 & 17 & 24 & 26 & 29 & 20 & 2 & 12 & 206\end{array}$

$\begin{array}{llllllllllllll}1956 & 29 & 29 & 12 & 16 & 18 & 18 & 28 & 20 & 23 & 16 & 5 & 0 & 214\end{array}$

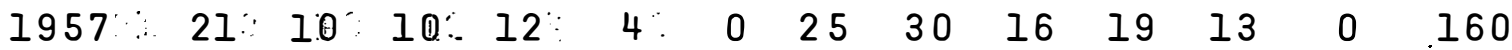

$\begin{array}{lllllllllllrrr}1958 & 24 & 19 & 14 & 1 & 0 & 6 & 21 & 27 & 11 & 14 & 8 & 12 & 157\end{array}$

$\begin{array}{llllllllllllll}1959 & 20 & 27 & 7 & 26 ! & 8 & 18 & 26 & 24 & 18 & 14 & 1 & 2 & 191\end{array}$

$\begin{array}{llllllllllllll}1960 & 0 & 19 & 0 & 10 & 20 & 29 & 20 & 16 & 23 & 19 & 9 & 15 & 180\end{array}$

$\begin{array}{llllllllllllll}1961 & 12 & 9 & 21 & 25 & 0 & 18 & 25 & 20 & 23 & 27 & 8 & 12 & 200\end{array}$

$\begin{array}{llllllllllllll}1962 & 0 & 6 & 25 & 16 & 11 & 20 & 17 & 31 & 19 & 9 & 1 & 2 & 157\end{array}$

$\begin{array}{llllllllllllll}1963 & 24 & 17 & 28 & 13 & 23 & 23 & 25 & 18 & 30 & 17 & 6 & 11 & 235\end{array}$

$\begin{array}{llllllllllllll}1964 & 0 & 9 & 0 & 6 & 9 & 6 & 12 & 0 & 24 & 10 & 1 & 3 & 80\end{array}$

$\begin{array}{llllllllllllll}1965 & 11 & 7 & 4 & 0 & 4 & 11 & 14 & 28 & 22 & 9 & 9 & 16 & 135\end{array}$

$\begin{array}{llllllllllllll}1966 & 10 & 28 & 31 & 3 & 17 & 7 & 11 & 29 & 28 & 5 & 2 & 9 & 180\end{array}$

$\begin{array}{llllllllllllll}1967 & 4 & 4 & 15 & 14 & 0 & 18 & 12 & 25 & 28 & 29 & 10 & 0 & 159\end{array}$

$\begin{array}{llllllllllllll}1968 & 16 & 6 & 15 & 16 & 17 & 26 & 19 & 7 & 9 & 0 & 12 & 12 & 155\end{array}$

$\begin{array}{llllllllllllll}1969 & 12 & 24 & 15 & 9 & 25 & 5 & 12 & 26 & 29 & 12 & 0 & 0 & 169\end{array}$

$\begin{array}{llllllllllllll}1970 & 6 & 24 & 13 & 13 & 28 & 30 & 13 & 7 & 11 & 8 & 0 & 21 & 174\end{array}$

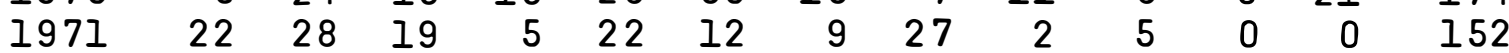

$\begin{array}{llllllllllllll}1972 & 20 & 18 & 24 & 15 & 20 & 18 & 10 & 11 & 8 & 7 & 2 & 0 & 153\end{array}$

$\begin{array}{llllllllllllll}1973 & 20 & 13 & 4 & 11 & 19 & 27 & 24 & 16 & 23 & 6 & 0 & 0 & 168\end{array}$

$\begin{array}{llllllllllllll}1974 & 4 & 16 & 29 & 7 & 1- & 22 & 30 & 31 & 21 & 12 & 8 & 2 & 198\end{array}$

$\begin{array}{llllllllllllll}1975 & 10 & 13 & 15 & 9 & 5 & 4 & 19 & 31 & 13 & 0 & 3 & 12 & 134\end{array}$

$\begin{array}{llllllllllllll}1976 & 31 & 25 & 18 & 15 & 15 & 30 & 11 & 21 & 0 & 2 & 7 & 0 & 175\end{array}$ 
Apêndice 3 - Períodos de dias secos consecutivos de li:a 31 dias, por mês, nos 37 anos $(1940$ - 1976), para $35 \mathrm{~mm}$ de $: \bar{a}-$ gua disponivel no solo.

DIAS

NQ DE SE Q U E N C I A S

SECOS jan fev mar abr mai jun jul ago set out nov dez totais

$\begin{array}{rrrrrrrrrrrrrr}r 1 & 11 & 11 & 10 & 8 & 13 & 7 & 15 & 8 & 8 & 6 & 18 & 10 & 125 \\ 2 & 10 & 9 & 12 & 8 & 9 & 9 & 5 & 9 & 6 & 8 & 8 & 7 & 100 \\ 3 & 7 & 7 & 7 & 4 & 10 & 3 & 5 & 3 & 12 & 8 & 5 & 1 & 72 \\ 4 & 6 & 6 & 3 & 7 & 8 & 4 & 9 & 6 & 4 & 12 & 4 & 4 & 73 \\ 5 & 41: & 4 & 7 & 9 & 8 & 2 & 7 & 5 & 4 & 4 & 4 & 3 & 61 \\ 6 & 4 & 4 & 3 & 5 & 3 & 2 & 5 & 3 & 3 & 6 & 4 & 2 & 44 \\ 7 & 4 & 4 & 6 & 3 & 3 & 1 & 4 & 1 & 2 & 3 & 1 & 2 & 34 \\ 8 & 3 & 0 & 5 & 7 & 2 & 5 & 6 & 2 & 4 & 6 & 3 & 2 & 45 \\ 9 & 1 & 5 & 3 & 3 & 4 & 3 & 5 & 2 & 1 & 1 & 3 & 0 & 31 \\ 10 & 3 & 2 & 1 & 1 & 5 & 2 & 3 & 2 & 2 & 1 & 1 & 1 & 24 \\ 11 & 2 & 3 & 4 & 1 & 2 & 2 & 0 & 2 & 4 & 3 & 2 & 3 & 28 \\ 12 & 1 & 0 & 0 & 1 & 1 & 3 & 1 & 4 & 4 & 0 & 0 & 1 & 16 \\ 13 & 1 & 1 & 0 & 1 & 1 & 1 & 3 & 2 & 4 & 0 & 0 & 0 & 14 \\ 14 & 3 & 1 & 2 & 2 & 1 & 0 & 1 & 1 & 2 & 2 & 0 & 1 & 16 \\ 15 & 2 & 1 & 3 & 1 & 0 & 0 & 2 & 4 & 0 & - & 0 & 0 & 15 \\ 16 & 2 & 2 & 1 & 1 & 2 & 2 & 3 & 4 & 2 & 1 & 0 & 0 & 20 \\ 17 & 0 & 2 & 2 & 0 & 2 & 1 & 1 & 1 & 0 & 0 & 0 & 0 & 9 \\ 18 & 1 & 2 & 1 & 1 & 0 & 4 & 2 & 0 & 1 & 2 & 0 & 0 & 14 \\ 19 & 1 & 2 & 3 & 1 & 1 & 2 & 2 & 1 & 1 & 2 & 0 & 0 & 16 \\ 20 & 2 & - & 0 & 0 & 1 & 0 & 3 & 3 & 1 & 0 & 0 & 0 & 10 \\ 21 & 0 & 0 & 0 & 0 & 0 & 1 & 0 & 2 & 2 & 0 & 0 & 1 & 6 \\ 22 & 0 & 0 & 0 & 0 & 0 & 2 & 0 & 0 & 2 & 0 & 0 & 0 & 4 . \\ 23 & 0 & 0 & 0 & 0 & 0 & 0 & 0 & 1 & 11 & 0 & 1 & 0 & 3 \\ 24 & 0 & 2 & 1 & 0 & 1 & 0 & 2 & 2 & 1 & 0 & 0 & 0 & 9 \\ 25 & 0 & 0 & 0 & 0 & 0 & 0 & 0 & 1 & 1 & 0 & 0 & 0 & 2 \\ 26 & 1 & 0 & 0 & 0 & 0 & 0 & 0 & 1 & 0 & 0 & 0 & 0 & 2 \\ 27 & 0 & 0 & 0 & 0 & 0 & 2 & 0 & 1 & 0 & 1 & 0 & 0 & 4 \\ 28 & 0 & 4 & 1 & 0 & 0 & 1 & 0 & 0 & 1 & 0 & 0 & 0 & 7 \\ 29 & 0 & 1 & 0 & 0 & 0 & 0 & 1 & 0 & 0 & 1 & 0 & 0 & 3 \\ 30 & 0 & 0 & 0 & 0 & 0 & 3 & 0 & 0 & 3 & 0 & 0 & 0 & 6 \\ 31 & 1 & 0 & 1 & 0 & - & 0 & 0 & 3 & 0 & 0 & 0 & 0 & 5 \\ & & & & & & & & & & & & \end{array}$


Apêndice 4 - Períodos de dias secos consecutivos computados por trimestre, nos 37 anos $(1940-1976), \quad$ para $35 \mathrm{~mm}$ de àgua disponível no solo.

Dias
Secos

Número de Sequências

19 Trim. 29 Trim• 39 Trim• 49 Trim. 'Totais

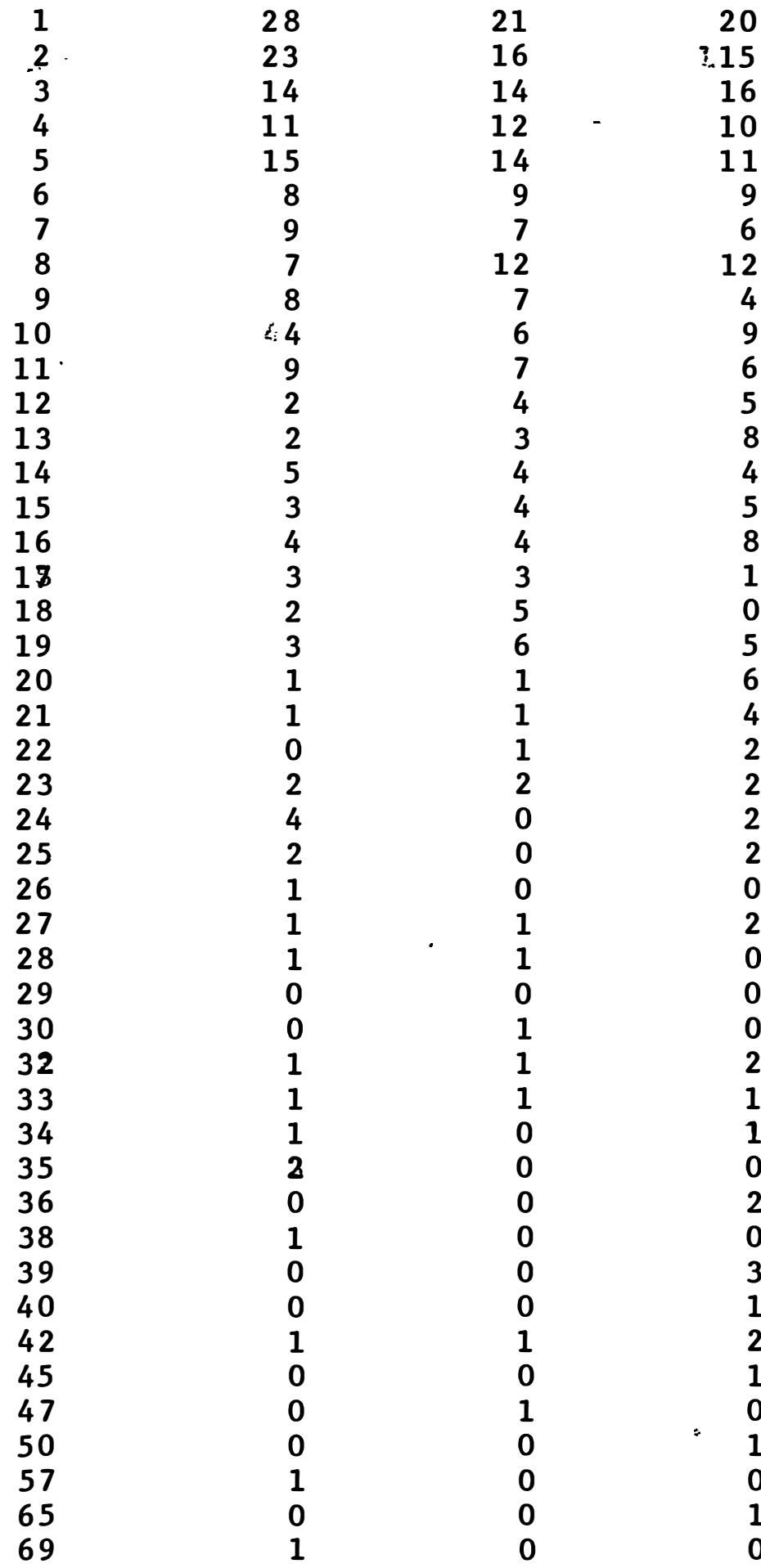

28

97

$20: 74$

$16 \quad 12 \quad 56$

$10 \quad 19 \div 52$

$11 \quad 10 \quad 50$

$9 \quad 12 \quad 38$

$6 \quad 7 \quad 29$

$12 \quad 10 \quad 41$

423

21

29

13

13

16

15

17

18

29

115

0

$0-3$

1

1

$0 \quad 1$

$2 \quad 1$

$0 \quad 0 \quad 0 \quad 2$

$0 \quad 1$

$0 \quad 0$

10

2

0
0

0

0

0

0

0

0

0

$\begin{array}{ll}0 & 1 \\ 0 & 1\end{array}$ 
Apêndice 5 - Classes das maiores sequências de dias secos em cada mês, sua frequência, porcentagem e porcentagem acumulada, nos 37 anos, para $35 \mathrm{~mm}$ de água dis ponível no solo.

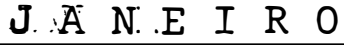

Freq.

$\%$

$\%$ acum.

$$
10,81
$$

100,00

10,81

89,19

78,38

59,46

5,41

$$
16,22
$$

16,22

8,11

8,11

0,00

2,70

2,70

1

1

$$
54,05
$$

54,05

21,62

13,51

5,41

5,41

2,70
?.Zemo

1 a 3

4 a 6

7 a 9

10 a 12

13 a 15

16 a 18

19 a 21

22 a 24

25 a 27

28 a 31

\section{F E V E R E I R 0}

Freq.

$\% \quad \%$ acum.

$\begin{array}{rrr}1 & 2,70: & 100,00 \\ 1 & 2,70 & 97,30 \\ 6 & 16,22 & 94,59 \\ 6 & 16,22 & 78,38 \\ 5 & 13,51 & 62,16 \\ 3 & 8,11 & 48,65 \\ 6 & 16,22 & 40,54 \\ 2 & 5,41 & 24,32 \\ 2 & 5,41 & 18,92 \\ 0 & 0,00 & 13,51 \\ 5 & 13,51 & 13,51\end{array}$

$M A R \& O$

Freq. $\%$ acum

\begin{tabular}{rrrr}
2 & 5,41 & 100,00 & \multicolumn{2}{c}{ Zero } \\
2 & 5,41 & 94,59 & 1 a 3 \\
4 & 10,81 & 89,19 & 4 a 6 \\
10 & 27,03 & 78,38 & 7 a 9 \\
4 & 10,81 & 51,35 & 10 a 12 \\
5 & 13,51 & 40,54 & 13 a 15 \\
4 & 10,81 & 27,03 & 16 a 18 \\
3 & 8,11 & 16,22 & 19 a 21 \\
1 & 2,70 & 8,11 & 22 a 24 \\
0 & 0,00 & 5,41 & 25 a 27 \\
2 & 5,41 & 5,41 & 28 a 31
\end{tabular}

CLASSES

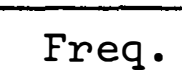

A B R I L

2
4
10
11
3
4
2
1
0
0
0

$\%$ acum.

$$
5,41 \quad 100,00
$$$$
10,81
$$

94,59

27,03

83,78

29,73

56,76

8,11

27,03

10,81

$18,-2$

5,41

8,11

2,70

2,70

0,00

$0,0,0$

0,00

0,00

0,00

0,00 
Apêndice 5 - Continuação.

M A I 0

Freq.

3

7

7

6

2

4

2

1

0

0
$\%$

13,51
8,11
18,92
18,92
16,22
5,41
10,81
5,41
2,70
0,00
0,00

$\%$ acum.

100,00

86,49

78,38

59,46

40,54

24,32

18,92

$\therefore 8,11$

2,70

0,00

0,00
CLASSES

J $\mathrm{U} \mathrm{N} \mathrm{HO}$

Freq.

$\%$

$\%$ acum.

Zero

1 a 3

4 a 6

7 a 9

10 a 12

13 a 15

16 a 18

19 a 21

22 a 24

25 a 27

28 a 31
1

2

4

6

5

1

7

3

2

2

4

$$
\begin{array}{r}
2,70 \\
5,41 \\
10,81 \\
16,22 \\
13,51 \\
2,70 \\
18,92 \\
8,11 \\
5,41 \\
5,41
\end{array}
$$$$
10,81
$$

100,00

97,30

91,89

81,08

64,86

51,35

48,65

29,73

21,62

16,22

10,81

\section{J U L H O}

\section{Freq.}

\begin{tabular}{l}
0 \\
0 \\
7 \\
8 \\
2 \\
6 \\
5 \\
\hline
\end{tabular}

$\%$ acum.

100,00

100,00

0,00

18,92

21,62

5,41

16,22

16,22

13,51

5,41

0,00

2,70

100,00

81,08

59,46

54,05

37,84

21,62

8,11

2,70

2,70

CLASSES

Zero

1 a 3

4 a 6

7 a 9

10 a 12

13 a 15

16 a 18

19 a 21

22 a 24

25 a 27

28 a 31

\section{$A G O S T O$}

Freq.

$\%$

$\%$ acum.

1
0
4
1
5
6
5
6
3
3
3

2,70

100,00

0,00

97,30

10,81

97,30

2,70

86,49

13,51

83,78

16,22

70,27

13,51

54,05

16,22

40,54

8,11

24,32

8 , II

16,22

8,11

8,11 
Apêndice 5 - Continuação.

\section{S E T E M B R O}

Freq. $\%$ acum.

\begin{tabular}{lrrrrl}
1 & 2,70 & 100,00 & \multicolumn{2}{l}{ Zero } \\
1 & 2,70 & 97,30 & 1 a 3 \\
3 & 8,11 & 94,59 & 4 a 6 \\
3 & 8,11 & 86,49 & 7 a & 9 \\
7 & 18,92 & 78,38 & 10 a 12 \\
6 & 16,22 & 59,46 & 13 a 15 \\
3 & 8,11 & 43,24 & 16 a & 18 \\
4 & 10,81 & 35,14 & 19 a 21 \\
4 & 10,81 & 24,32 & 22 a 24 \\
1 & 2,70 & 13,51 & 25 a 27 \\
4 & 10,81 & 10,81 & 28 a 31
\end{tabular}

N O

Freq. $\quad \% \quad \%$ acum.

CLASSES

\begin{tabular}{rrrll}
7 & 18,92 & 100,00 & \multicolumn{2}{l}{ Zero } \\
12 & 32,43 & 81,08 & 1 a 3 \\
7 & 18,92 & 48,65 & 4 a & 6 \\
7 & 18,92 & 29,73 & 7 a & 9 \\
3 & 8,11 & 10,81 & 10 a & 12 \\
0 & 0,00 & 2,70 & 13 a : 15 \\
0 & 0,00 & 2,70 & 16 a 18 \\
0 & 0,00 & 2,70 & 19 a 21 \\
1 & 2,70 & 2,70 & 22 a & 24 \\
0 & 0,00 & 0,00 & 25 a 27 \\
0 & 0,00 & 0,00 & 28 a & 31
\end{tabular}

O U T U B R O

Freq.

$\%$

\& acum.

$\begin{array}{rrr}2 & 5,41 & 100,00 \\ 2 & 5,41 & 94,59 \\ 9 & 24,32 & 89,19 \\ 9 & 24,32 & 64,86 \\ 4 & 10,81 & 40,54 \\ 4 & 10,81 & 29,73 \\ 3 & 8,11 & 18.92 \\ 2 & 5,41 & 10,81 \\ 0 & 0,00 & 5,41 \\ 1 & 2,70 & 5,41 \\ 1 & 2,70 & 2,70\end{array}$

D E Z E M B R 0

Freq.

$\%$ acum.

13

35,14

100,00

10

27,03

64,86

4

10,81

37,84

3

8,11

27,03

5

13,51

18,92

1

2,70

5,41

0

0,00

2,70

1

2,70

2,70

0,00

0,00

0,00

0,00

0,00

0,00 